\title{
ART CCIM Phase II-A Off-Gas System Evaluation Report
}

Nick Soelberg

Jay Roach

Mike Ancho

John Richardson

April 2009

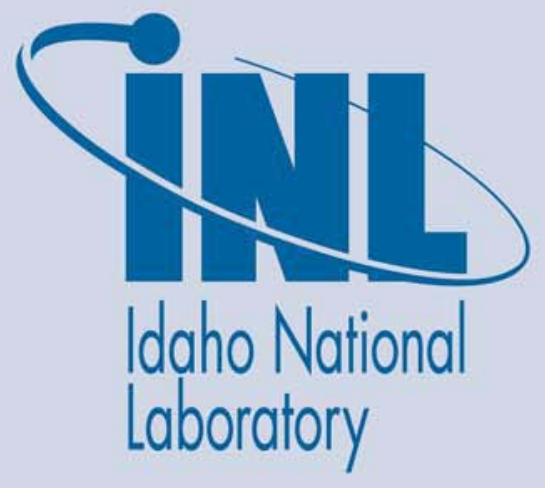

The INL is a U.S. Department of Energy National Laboratory operated by Battelle Energy Alliance 
INL/EXT-09-15711

\title{
ART CCIM Phase II-A Off-Gas System Evaluation Report
}

\author{
Nick Soelberg \\ Jay Roach \\ Mike Ancho \\ John Richardson
}

April 2009

\begin{abstract}
Idaho National Laboratory
Idaho Falls, Idaho 83415
\end{abstract}

http://www.inl.gov

Prepared for

AREVA Federal Services LLC

and for the

US Department of Energy

Under DOE Idaho Operations Office

Contract DE-AC07-05ID14517 


\section{APPROVALS}

\begin{tabular}{|l|l|c|c|}
\hline \multicolumn{1}{|c|}{ Name } & \multicolumn{1}{|c|}{ Title } & Signature \\
\hline Nick Soelberg & Project Engineer & Date \\
\hline Jay Roach & Department Manager & 27 APriLOS \\
\hline Eric Tchemitcheff & AREVA Project Manager & \\
\hline
\end{tabular}




\section{EXECUTIVE SUMMARY}

\section{Background}

AREVA Federal Services (AFS) is performing a multi-year, multi-phase Advanced Remediation Technologies (ART) project, sponsored by the United States (US) Department of Energy (DOE), to evaluate the feasibility and benefits of replacing the existing joule-heated melter (JHM) used to treat high level waste (HLW) in the Defense Waste Processing Facility (DWPF) at the Savannah River Site with a cold crucible induction melter (CCIM). The ART CCIM project includes several collaborators from AREVA subsidiaries, French companies, and DOE national laboratories. The Savannah River National Laboratory and the Commissariat a l'Energie Atomique (CEA) have performed laboratory-scale studies and testing to determine a suitable, high-waste-loading glass matrix. The Idaho National Laboratory (INL) and CEA are performing CCIM demonstrations at two different pilot scales to assess CCIM design and operation for treating SRS sludge wastes that are currently being treated in the DWPF. SGN is performing engineering studies to validate the feasibility of retrofitting CCIM technology into the DWPF Melter Cell. The long-term project plan includes more lab-testing, pilot- and large-scale demonstrations, and engineering activities to be performed during subsequent project phases.

\section{Off-gas System Evaluation Results}

The Off-gas System Evaluation (OGSE) demonstration was performed using the INL CCIM engineering-scale system. A simulant of the pre-treated (acidified by formic acid addition) DWPF SB4 feed was successfully fed and melted during two demonstration series - a 30-hour parametric demonstration, and the 58-hour OGSE demonstration. During the OGSE demonstration, nonradioactive Cs was spiked into the feed. The glass level gradually increased as the simulant was continuously fed to the melter, until a portion of the molten glass was drained from the melter. The glass drain was operated periodically, on-demand. A cold cap of unmelted feed was controlled by adjusting the feedrate and melter power levels to obtain the target molten glass temperatures with varying cold cap levels.

Three operating conditions were demonstrated, with the molten glass melt target temperature of either $1,250^{\circ} \mathrm{C}$ or $1,300^{\circ} \mathrm{C}$, and with either a partial or complete cold cap of unmelted feed on top of the molten glass. The melter off-gas composition was continuously monitored during operation. Samples of all input and output streams including the starting glass, the simulant feed, the off-gas particulate matter, product glass, and deposits removed from the crucible and off-gas pipe after the demonstration were collected for analysis. The fate of feed organic and metal feed constituents and metals partitioning was determined. The melter off-gas source term to a downstream off-gas system was characterized. Additional results include:

- Melter off-gas $\mathrm{H}_{2}$ levels measured by the continuous emissions monitoring system (CEMS) were low, ranging between $0.05-0.07 \%$ (wet basis). Gas chromatography analysis of summa canister TO-14 grab samples confirmed the low levels measured by the CEMS.

- About $98 \%$ of the carbon in the formate in the simulant feed converted to $\mathrm{CO}_{2}$, and over $90 \%$ of the $\mathrm{H}$ converted to water vapor. Under $6-9 \%$ of the $\mathrm{H}$ in the formate converted to $\mathrm{H}_{2}$, and $2 \%$ of the formate decomposed to gaseous hydrocarbons or CO.

- The total off-gas particulate matter averaged $0.26 \%$ of the total calcined solids input rate.

- Cs partitioning to the off-gas averaged about $11 \%$, and decreased from about $17 \%$ to about $10 \%$ when the cold cap coverage was increased from $70 \%$ to $90-95 \%$. 


\section{ACKNOWLEDGEMENTS}

The authors thank the many contributors to the success of the Advanced Remediation Technology (ART) Cold Crucible Induction Melter (CCIM) Off-gas System Evaluation (OGSE) demonstration. The OGSE demonstration was one of several components of the ART CCIM Phase II-A project, funded by the US Department of Energy under the direction of Kurt Gerdes of DOE Environmental Management. The project was managed by Eric Tchemitcheff with the support of Joseph Buchanan and Fred Renz, all of AREVA Federal Services (AFS). Other ART CCIM project participants who are performing other components of the project, and who have helped plan the OGSE demonstration, include Christophe Girold and Alain Ledoux of Commissariat a l'Energie Atomique (CEA), Julien Lauzel of SGN, Catherine Veyer (consultant), and Sharon Marra, Jim Marra, and Alex Choi of Savannah River National Laboratory (SRNL).

The Idaho National Laboratory performed the OGSE demonstration under a Work-for-Others project for AFS. INL project team members included Stephen Priebe and Kip Archibald, who helped prepare and operated the CCIM demonstration system during round-the-clock operation. Roy Woodvine of S. M. Stoller Corporation also helped prepare the CCIM demonstration system, and performed the melter offgas sampling. Science Applications International Corporation (SAIC) provided off-gas sampling and analysis support.

The OGSE demonstration generated many samples that were analyzed in laboratories at the SRNL, the INL, and TestAmerica, Incorporated. 


\section{CONTENTS}

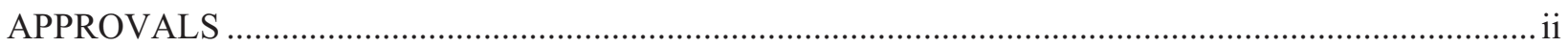

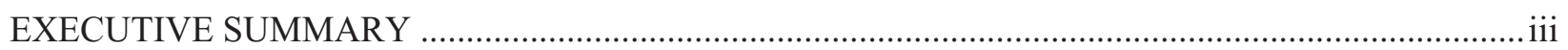

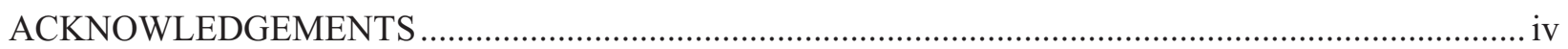

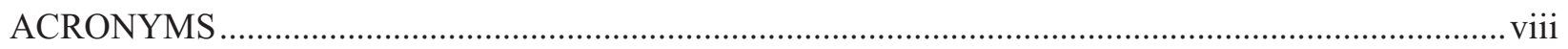

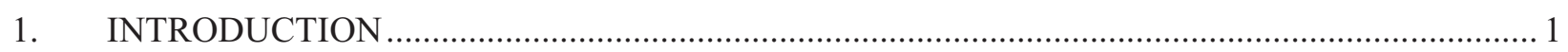

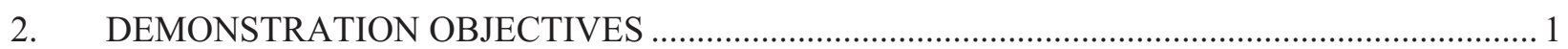

3. INL ENGINEERING SCALE CCIM DEMONSTRATION SYSTEM.......................................... 2

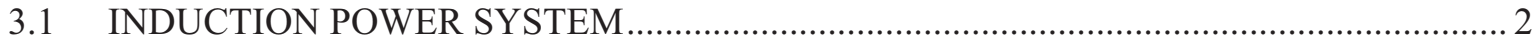

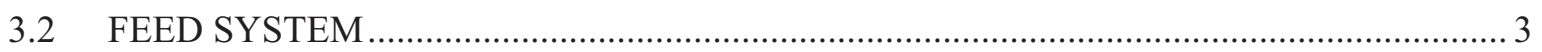

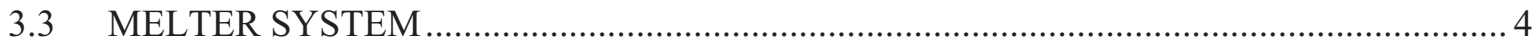

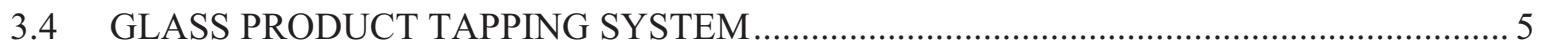

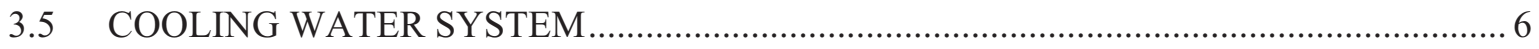

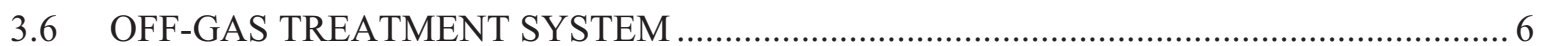

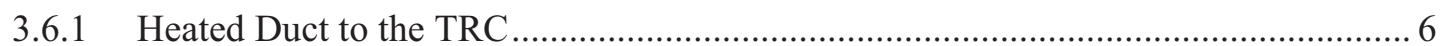

3.6.2 Thermal Reaction Chamber .................................................................. 8

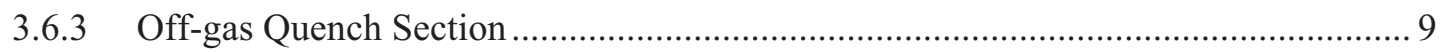

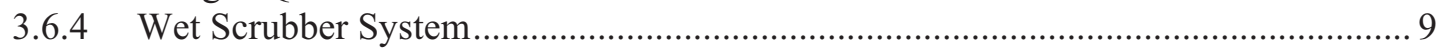

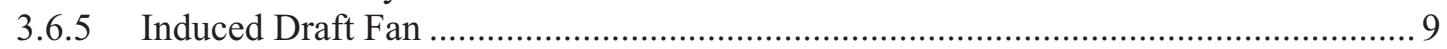

3.7 PROCESS MONITORING AND CONTROL SYSTEM ................................................. 9

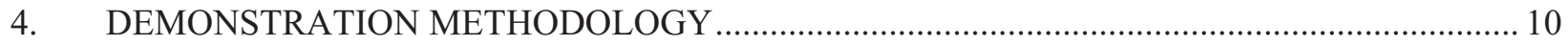

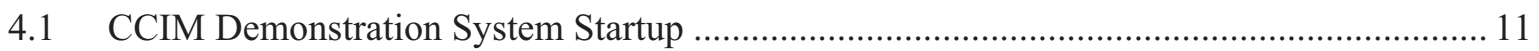

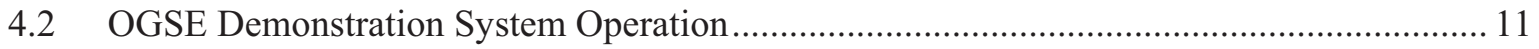

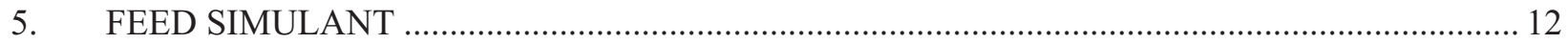

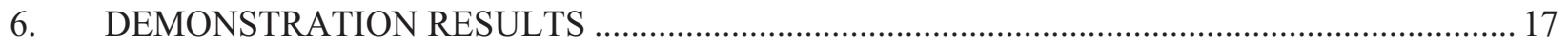

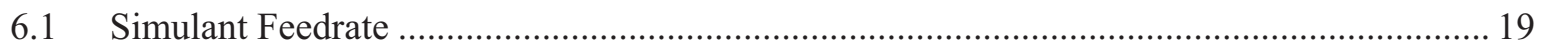

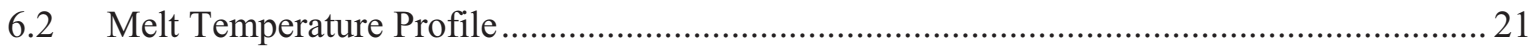

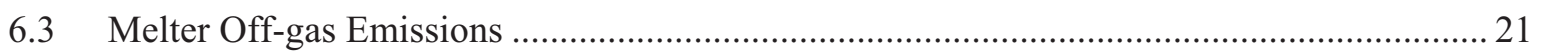

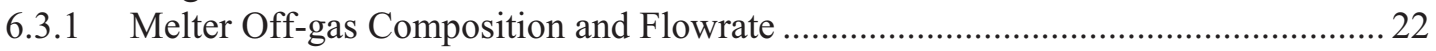

6.3.2 Fate of Formate in the Simulant Feed ................................................................. 27

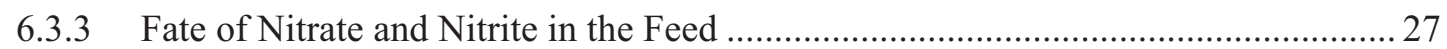

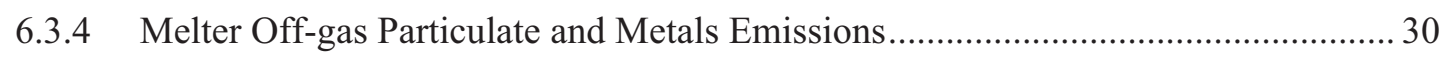

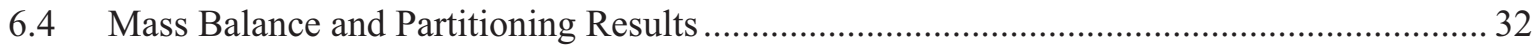

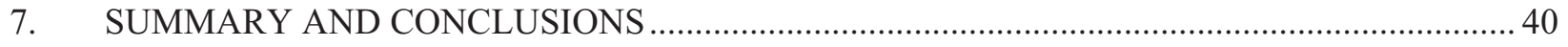

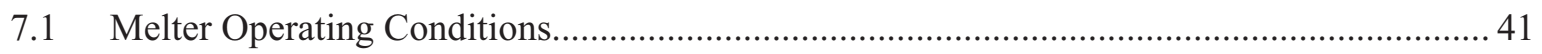




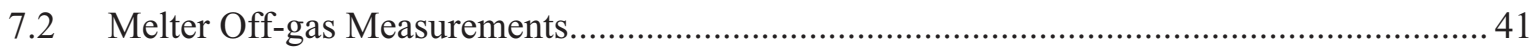

7.3 Mass Balance and Partitioning Results ............................................................................ 42

8. REFERENCES

\section{FIGURES}

Figure 3-1. Simplified process schematic of the INL CCIM demonstration system. ............................... 3

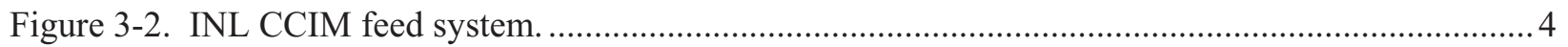

Figure 3-3. INL CCIM cooling water system schematic. .................................................................... 7

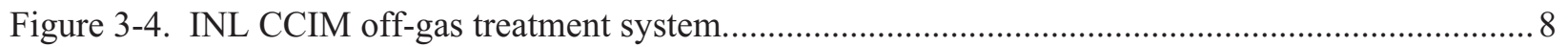

Figure 6-1. Off-gas System Evaluation demonstration temperature and power levels............................ 18

Figure 6-2. Off-gas System Evaluation demonstration feed and melter parameters. .............................. 18

Figure 6-3. Molten glass draining from the melter through the bottom tap hole...................................20

Figure 6-4. Specific feedrate and freeboard temperature for different cold cap coverage levels. .............21

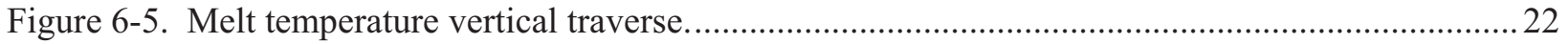

Figure 6-6. $\mathrm{CO}_{2}, \mathrm{H}_{2}$, and $\mathrm{CO}$ concentrations in the melter off-gas on a dry basis................................25

Figure 6-7. $\mathrm{CH}_{4}$, THC (reported as $\mathrm{CH}_{4}$ ), $\mathrm{O}_{2}, \mathrm{NO}$, and $\mathrm{NO}_{\mathrm{x}}$ concentrations in the melter off-gas

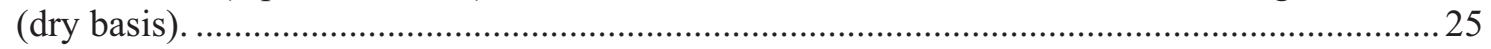

Figure 6-8. $\mathrm{CO}_{2}, \mathrm{H}_{2}$, and $\mathrm{CO}$ concentrations in the melter off-gas (wet basis). ...................................26

Figure 6-9. $\mathrm{CH}_{4}$, THC (reported as $\mathrm{CH}_{4}$ ), $\mathrm{O}_{2}, \mathrm{NO}$, and $\mathrm{NO}_{\mathrm{x}}$ concentrations in the melter off-gas

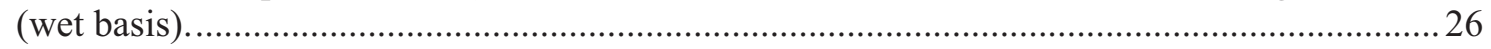

Figure 6-10. Fate of formate in the feed during CCIM processing......................................................29

Figure 6-12. Total particulate matter, $\mathrm{Cs}$, and Fe emission rates for the different demonstration

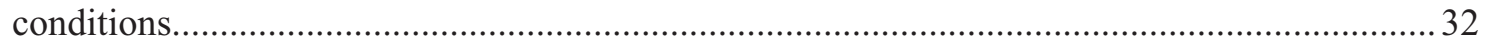

Figure 6-13. Average elemental and total solid mass balance closure.................................................. 37

Figure 6-14. Average Enrichment/depletion of metals concentrations in the off-gas particulate

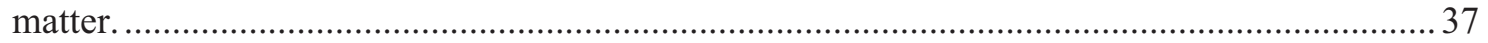

Figure 6-15. Average metals and total solids partitioning to the off-gas............................................. 38

Figure 6-16. Metals and total calcined solids partitioning to the off-gas for different cold cap coverages.

\section{TABLES}

Table 5-1. Sludge Batch 4 waste simulant, fabricated by Harrell Industries, Inc., analytical results ........ 13

Table 5-2. Glass frit 503-R6 analytical results (Tchemitcheff 2009).................................................. 14

Table 5-3. Calculated composition of simulant SB4 feed slurry including glass frit 503 R6.................. 15 
Table 5-4. Startup glass (503-R6/SB4 at $46 \mathrm{wt} \%$ waste loading) analytical results (Tchemitcheff 2009).

Table 6-1. Melter system conditions during the melter off-gas sampling periods................................... 19

Table 6-2. Dry-basis melter off-gas composition, fate of formate, and $\mathrm{NO}_{\mathrm{x}}$ speciation........................... 23

Table 6-3. Wet-basis melter off-gas flowrate and composition, melter off-gas air dilution factor, and $\mathrm{NO}_{\mathrm{x}}$ destruction.

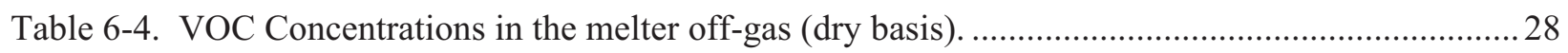

Table 6-5. Melter off-gas particulate and metals concentrations and emission rates............................... 31

Table 6-6. Input and output stream compositions (used in mass balance calculations) and other product glass properties. 33

Table 6-7. Average mass balance closure and partitioning calculations................................................. 35

Table 6-8. Instantaneous metals partitioning for the different demonstration conditions. 39 


\section{ACRONYMS}

$\begin{array}{ll}\text { APAD } & \text { Air Permit Applicability Determination } \\ \text { AFS } & \text { AREVA Federal Services LLC } \\ \text { ART } & \text { Advanced Remediation Technologies } \\ \text { CCIM } & \text { cold crucible induction melter } \\ \text { CEA } & \text { Commissariat a l'Energie Atomique } \\ \text { CEM } & \begin{array}{l}\text { continuous emissions monitoring } \\ \text { CEMS }\end{array} \\ \text { continuous emissions monitoring system } \\ \text { DACS } & \text { data acquisition and control system } \\ \text { DOE } & \text { Department of Energy } \\ \text { DWPF } & \text { Defense Waste Processing Facility } \\ \text { EPA } & \text { Environmental Protection Agency } \\ \text { GC } & \text { gas chromatography } \\ \text { GC/MS } & \text { gas chromatography / mass spectroscopy } \\ \text { HLW } & \text { high level waste } \\ \text { HM } & \text { H-Area modified } \\ \text { ID } & \text { induced draft } \\ \text { IDL } & \text { instrument detection limit } \\ \text { IEDF } & \text { INL Engineering Demonstration Facility } \\ \text { INL } & \text { Idaho National Laboratory } \\ \text { ISMS } & \text { Integrated Safety Management System } \\ \text { JHM } & \text { joule-heated melter } \\ \text { LI } & \text { Laboratory Instruction } \\ \text { MDL } & \text { method detection limit } \\ \text { mg/wncm } & \text { mg per wet normal cubic meter } \\ \text { mg/wscf } & \text { mg per wet standard cubic foot } \\ \text { OGSE } & \text { Off-gas System Evaluation } \\ \text { P\&ID } & \text { process and instrumentation diagram } \\ \text { PIC } & \text { products of incomplete combustion } \\ \text { PM } & \text { particulate matter } \\ \text { REDOX } & \text { reduction/oxidation } \\ \text { RF } & \text { radio frequency } \\ \text { RL } & \text { Reporting Limit } \\ \text { SB4 } & \text { Sludge Batch 4 } \\ \text { SRAT } & \text { Savannah River National Laboratory } \\ \text { Sludge Receipt and Adjustment Tank } \\ \text { Savannah River Site } \\ \text { Thermocouple }\end{array}$




$\begin{array}{ll}\text { THC } & \text { total hydrocarbon } \\ \text { TRC } & \text { thermal reaction chamber } \\ \text { UDS } & \text { undissolved solids } \\ \text { US } & \text { United States } \\ \text { VOC } & \text { volatile organic compounds } \\ \text { WESP } & \text { wet electrostatic precipitator }\end{array}$


This page is intentionally blank 


\section{ART CCIM Phase II-A Off-gas System Evaluation Report}

\section{INTRODUCTION}

AREVA Federal Services (AFS) is performing a multi-year, multi-phase Advanced Remediation Technology (ART) project, sponsored by the United States (US) Department of Energy (DOE), to evaluate the feasibility and benefits of replacing the existing joule-heated melter (JHM) used to treat high level waste (HLW) in the Defense Waste Processing Facility (DWPF) at the Savannah River Site (SRS) with a cold crucible induction melter (CCIM). Compared to JHMs, CCIMs have features that can lead to (a) higher specific waste throughputs, (b) higher waste loadings in vitrified glass and smaller corresponding volumes of glass that require permanent disposal, and (c) potentially lower overall HLW treatment costs.

The ART CCIM project includes several collaborators from AREVA subsidiaries, French companies, and DOE national laboratories. The key project components and performers include:

- Laboratory-scale studies and testing performed by the Savannah River National Laboratory (SRNL) and the Commissariat a l'Energie Atomique (CEA) to determine a suitable, high-wasteloading glass matrix.

- Pilot-scale demonstrations using existing CCIM demonstration systems operated by CEA in Marcoule, France, and by the Idaho National Laboratory (INL), to assess CCIM design and operation for treating SRS sludge wastes that are currently being treated in the DWPF.

- Engineering studies by SGN to validate the feasibility of retrofitting CCIM technology into the DWPF Melter Cell.

- Development of a comprehensive plan (including cost and schedule) for lab-testing, pilot- and large-scale demonstrations, and engineering activities to be performed during subsequent project phases.

\section{DEMONSTRATION OBJECTIVES}

The INL Off-gas System Evaluation (OGSE) demonstration was performed to measure the off-gas composition and other properties to provide data to determine how the CCIM retrofit design can interface with, operate within the constraints of, the existing DWPF off-gas control system (Soelberg 2009). The fate of radioactive cesium (Cs) is of particular interest to determine its impact on the existing DWPF offgas system. This is important because the CCIM is expected to operate at a higher temperature of around $1,250^{\circ} \mathrm{C}$, thus potentially increasing the volatility of the $\mathrm{Cs}$, compared to JHMs which typically operate at or below $1,150^{\circ} \mathrm{C}$. The simulant recipe includes non-radioactive Cs spiked at levels higher than nominal expected radioactive Cs levels, to provide sufficient $\mathrm{Cs}$ to perform analyses and mass balances to measure this key parameter.

Demonstration features that accomplished this objective include:

- Operate the melter system while feeding a nonradioactive simulant representing a selected SRS HLW sludge waste, during operating conditions selected to represent potential conditions expected for larger CCIM systems. Operating conditions expected to influence off-gas emissions and the fate of feed constituents include (a) glass and freeboard temperatures, (b) use of melt 
agitation, (c) degree of cold cap coverage, and (d) freeboard gas turbulence and velocity. The simulant feedrate was set to achieve the target cold cap coverage level at selected melt temperatures. A single bubbler was used to provide melt agitation in addition to the convection currents in the glass caused by temperature differentials.

- Determine the melter off-gas source term to the off-gas system. This included measuring the off-gas composition and also measuring amounts and composition of entrained and volatilized particulate matter at the outlet of the melter, for selected melter operating conditions listed above.

- Determine compositions and masses of the product glass, and the glass reduction-oxidation (REDOX) level as indicated by the REDOX ratio $\left(\mathrm{Fe}^{+2} / \mathrm{Fe}^{\text {total }}\right)$.

- Determine the fate of key feed constituents (glass formers, radionuclide surrogates, toxic metal surrogates, nitrates/nitrites, and organics).

\section{INL ENGINEERING SCALE CCIM DEMONSTRATION SYSTEM}

The INL has developed and constructed a fully integrated CCIM demonstration system including solid and liquid/slurry feed systems, and a complete off-gas treatment system designed to comply with the most rigorous air emission regulatory requirements. This system includes sampling access and monitoring capabilities to measure and characterize off-gas emissions. It includes an integrated off-gas system that can destroy $\mathrm{NO}_{\mathrm{x}}$ and flammable gas emissions and scrub acid gases and particulate matter. It provides the capability to generate data to determine how the feed constituents partition throughout the system. The INL CCIM demonstration system (Figure 3-1) includes the following subsystems:

- Induction power system

- Feed system

- Melter system

- Glass product tapping system

- Cooling water system

- Off-gas control system

- Process monitoring and control system

\subsection{INDUCTION POWER SYSTEM}

Major components of the induction power system include a Taylor-Winfield Thermionic C-6000 radio frequency (RF) generator, a coil transfer relay, and the induction coil. The frequency generator itself consists of three subsystems - an enclosed plate transformer unit, a high frequency generator chassis, and a control workstation. The enclosed transformer receives $480 \mathrm{~V}$ input power from the INL Engineering Demonstration Facility (IEDF) and supplies nominal 15-kV, 3-phase power to the generator chassis. The $15 \mathrm{kV}$ transformer output, which is rectified with a 3-phase, full-wave bridge in the chassis, is subsequently filtered to provide low-ripple direct current to the triode oscillator. Varying the angle of the firing system allows programming the plate voltage to the triodes, thus controlling output power.

The induction power system provides induction power of up to $60 \mathrm{~kW}$. The power level is adjustable via the control panel or 4-20 mA computer interface continuously over the range of 10-60 kW. The generator can also be configured to provide full power at a single frequency over a frequency range of $200-400 \mathrm{kHz}$ and $1.7-4 \mathrm{MHz}$. The maximum design power output is $75 \mathrm{~kW}$, but overpower interlocks limit the maximum power to $60 \mathrm{kWe}$ without readjustment. The target frequency for this demonstration, to best emulate the energy deposition profile in the CEA CCIM demonstration system in Marcoule, France, is $1.6 \mathrm{MHz}$ (Girold 2008). The frequency for the OGSE demonstration has been adjusted to about $1.7 \mathrm{MHz}$ to closely match the target frequency. 


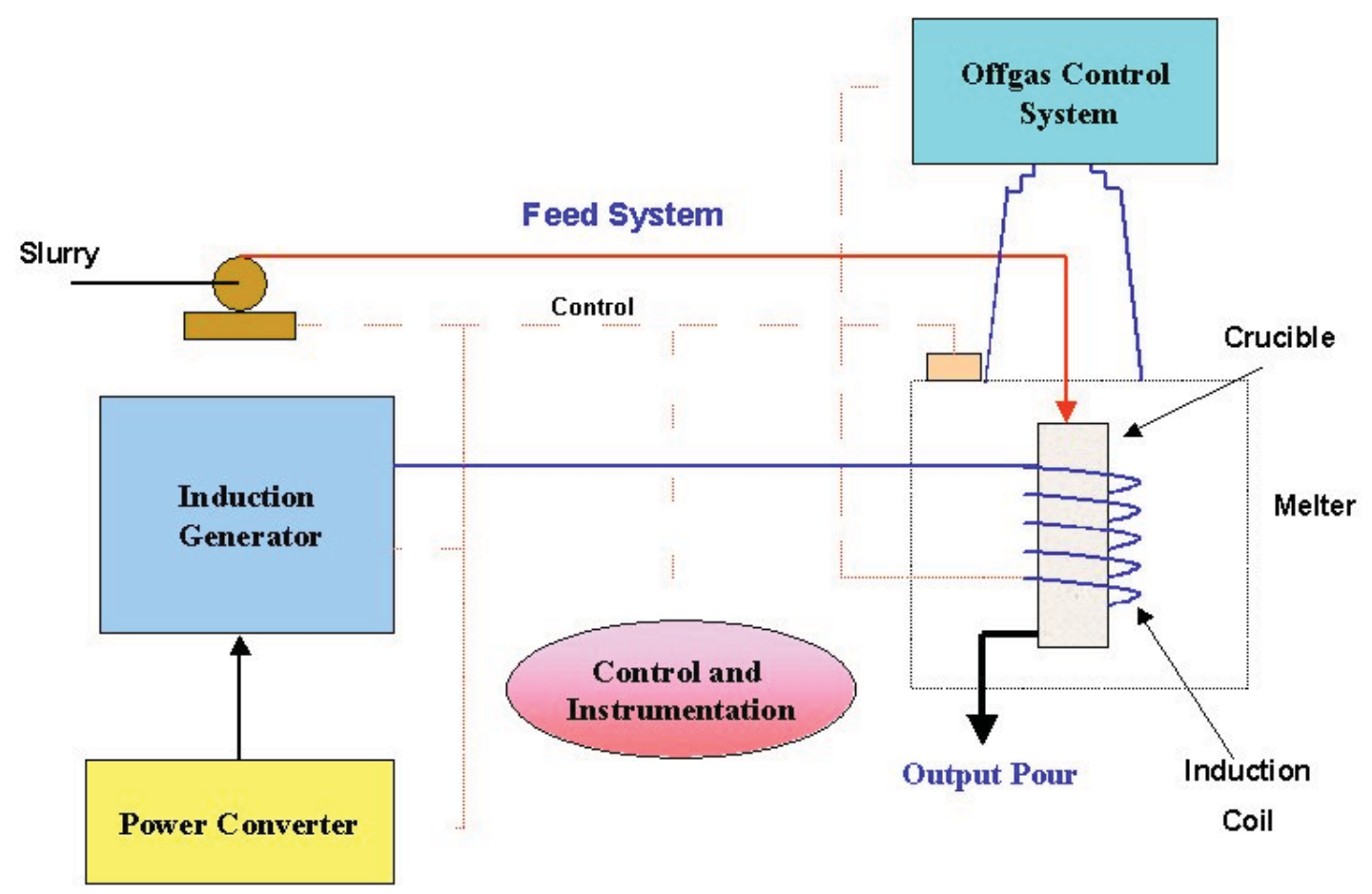

Figure 3-1. Simplified process schematic of the INL CCIM demonstration system.

A conductive metal cage encloses the melter and induction coil system, to ensure that workers are not exposed to unsafe levels of electromagnetic radiation, to prevent worker or equipment contact with high energy electrical conductors, and to protect the melter and induction coil equipment. Worker exposure to electromagnetic radiation is regulated by ANSI/IEEE Standard C95.1, "Standard for Safety Levels with Respect to Human Exposure to Radio Frequency Electromagnetic Fields, $3 \mathrm{KHz}$ to $300 \mathrm{GHz}$."

Operating parameters within the power supply system are continuously monitored. If certain conditions exceed preset safe values, the power supply system is automatically shut down. In addition, multiple and redundant safety interlocks are provided to protect operators.

\subsection{FEED SYSTEM}

The demonstration system includes feed systems for delivering liquid, slurry, or solid granular or powdered materials. The liquid feed system shown in Figure 3-2 includes a feed tank for mixing and feeding liquids or slurries. The feed tank is equipped with a stirrer, sparger, and recirculation loop to maintain homogeneity in slurry feed mixtures. A recirculation pump draws feed solution from the feed tank and recycles it back to the feed tank, which improves mixing in the feed tank. A separate metering pump provides melter feed flow metering and control, drawing feed from the recirculation loop. The separate flowmeter shown in the figure was bypassed during the OGSE demonstration.

The feed system is designed with the capability to feed water during startup and shutdown, and for flushing the feed system to clear it of potential plugging from undissolved solids (UDS) or glass frit in the feed slurry.

Feeds are deposited near the center of the crucible, on top of the melt. Three viewports enable visual and camera observation of the deposition of the feed on the melt surface. 


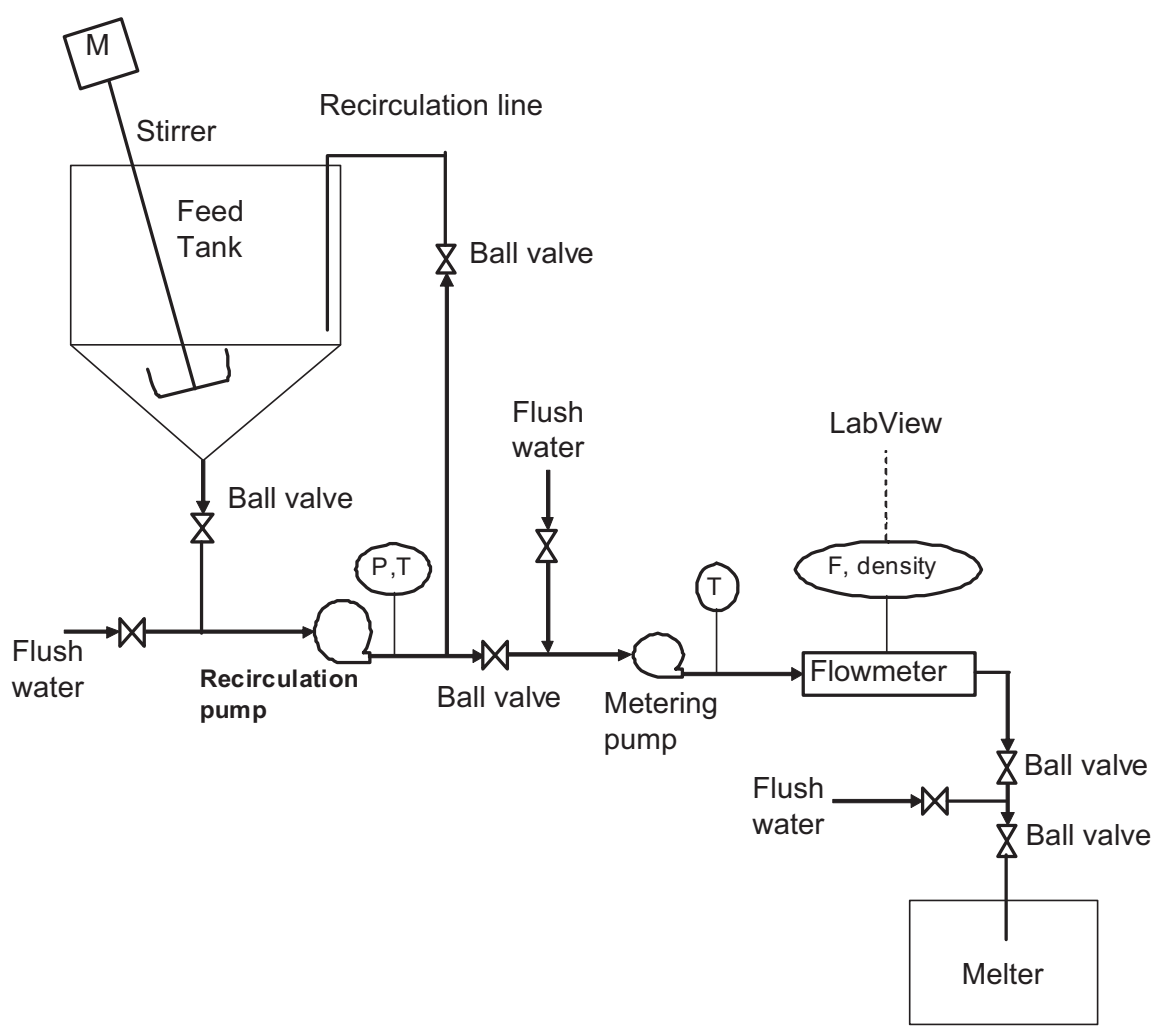

[ccim offgas system design calculations aug 2508 08.xls]Feed system

Figure 3-2. INL CCIM feed system.

\subsection{MELTER SYSTEM}

The melter crucible contains the molten melt material. It is constructed of 304L stainless steel, and consists of three primary components: the lower manifold, the upper manifold, and the cooling tubes. The crucible wall consists of vertical water-cooled tubes oriented to form a crucible cylinder with a nominal $26.7 \mathrm{~cm}$ (10.5 inches) internal diameter. The overall crucible height is $40.6 \mathrm{~cm}$ (16 inches).

During operation, the water-cooled tubes cause glass adjacent to the tubes to solidify into a solid skull wall that forms the crucible enclosure, while maintaining appropriate temperatures in the crucible walls. The crucible water cooling system can provide adequate cooling at the nominal full generator power $(60 \mathrm{~kW})$ and with a glass temperature up to $2,000^{\circ} \mathrm{C}$.

Liquid and solid feeds are fed to the top of the molten melt inside the melter crucible, using tubes that penetrate through the melter lid. Only a liquid slurry feed was used in the OGSE demonstration runs. Solid glass frit used at initial startup was added manually.

Melter startup was achieved using a conductive graphite ring placed in the startup glass frit, which coupled with the induction field. Resistance heating in the graphite ring heated the startup glass until it melted, at which time the molten glass was conductive enough to also couple with the induction field, until it was fully molten. After a short time (a few hours) with the air bubbler operating in the molten glass, tests show that the graphite ring is oxidized to $\mathrm{CO}$ and $\mathrm{CO}_{2}$ gas, and does not persist in the molten glass melt. 
When the feed slurry was started, the feed was heated and melted via heat transfer from the molten bath, which in turn was inductively heated by the electrical induction field. As the water in the slurry feed is evaporated, REDOX reactions occur between reductants and oxidants in the feed, and the dried residues heat to melt temperatures and become incorporated into the melt. New fresh feed is continuously or semicontinuously fed. During the OGSE demonstration, the feed was continuous except for a few short periods when the feed was turned off.

Available lid penetrations were as follows:

- Three view ports were used for visual and camera observations of the glass melt.

- One vertical port was used as the slurry feed port.

- One port was used for glass melt temperature measurements.

- One port was used for the air bubbler. The target air bubbler rate, to best emulate the operation of the CEA Marcoule CCIM, was 1-1.5 lpm (Girold 2008).

- One side port was used for sampling melter freeboard gas and for a thermal radiation-shielded melter freeboard gas temperature measurement.

Although multiple glass bubblers and a glass melt stirrer are used in the CEA Marcoule demonstration system for melt agitation, the ART CCIM Phase II-A project team concluded that stirring need not be included in the OGSE demonstration, and only a single bubbler was necessary, because of the small size of the melter used in the OGSE demonstration.

The crucible lid consists of an internal inconel shell that encloses the crucible freeboard space, which is covered with an outer stainless steel shell. The internal space between the inner and outer shells of the lid can be air or steam-cooled, or uncooled. Water cooling was not used here, as it would cause the lid to be too cool and cause condensation and deposition of material inside the lid during operation. No active cooling was used during the OGSE demonstration runs.

The melt height inside the crucible varies as the feed is continuously fed and the glass is semicontinuously tapped. The melt height can range between $10.2-30.5 \mathrm{~cm}$ ( $4-12$ inches), but the nominal design height is $26.7 \mathrm{~cm}$ (10.5 inches), equal to the melt diameter. The freeboard volume above the nominal melt height inside the crucible is $7,800 \mathrm{~cm}^{3}\left(476 \mathrm{in}^{3}\right)$. The melter lid, which is the same diameter and $15 \mathrm{~cm}$ (5 inches) high, adds $7,090 \mathrm{~cm}^{3}\left(433 \mathrm{in}^{3}\right)$. The total nominal freeboard volume is about 14,890 $\mathrm{cm}^{3}\left(909 \mathrm{in}^{3}\right)$.

\subsection{GLASS PRODUCT TAPPING SYSTEM}

As the molten bath volume increases from added melted feed, the glass is drained semicontinuously depending on the glass production rate. The existing crucible includes a bottom drain assembly, which allows draining the crucible down to about a 10-cm (4-inch) depth, so that a sufficient height of molten glass remains in crucible to remain coupled with the induction field.

The tapped glass exits the tapper and gravity drains into a receiving pan. The CCIM holds only a small molten glass inventory in process at any given time, ranging to as much as $17,000 \mathrm{~cm}^{3}\left(1,040 \mathrm{in}^{3}\right)$. The receiving pan is sized to contain the full volume of glass in the melter if necessary, to avoid spilling molten glass onto the laboratory floor in an event where the full glass volume of the melter is drained at one time. 


\subsection{COOLING WATER SYSTEM}

Several of the power supply and melter components are water cooled:

- The radiofrequency (RF) generator

- The induction coil

- The melter crucible

- Depending on design, the glass tapper

The cooling water system, shown in Figure 3-3, consists of two primary and secondary loops. One primary loop circulates de-ionized, non-electrically-conductive cooling water through the cooled components of the power generator and the induction coil. Another primary loop circulates city water through the crucible. Each primary loop exchanges heat through a separate liquid-liquid heat exchanger to separate secondary cooling loops. The secondary cooling loop for the power generator uses a water and propylene glycol mixture and is cooled in an outdoor water chiller. The secondary cooling loop for the crucible uses city water or an antifreeze mixture and an outdoor air convection radiator.

The CCIM power supply operation is interlocked with the cooling water outlet temperature, and is automatically de-energized if the cooling water outlet temperature exceeds a safe preset temperature and flowrate.

In the event of a failure of the crucible cooling system, both facility water and water that is gravity fed from an upper-deck reservoir can provide once-through cooling water. This ensures that, even if the crucible cooling water system fails, and the power to the melter is stopped, crucible cooling continues for a long enough time for the crucible to cool to a safe temperature $\left(<100^{\circ} \mathrm{C}\right)$ at which the water can be shut off.

\subsection{OFF-GAS TREATMENT SYSTEM}

The INL CCIM off-gas treatment system is shown in Figure 3-4. The system includes these components:

- Heated duct to the thermal reaction chamber (TRC)

- Thermal reaction chamber

- Off-gas quench section

- Wet scrubber system

- Induced draft fan

\subsubsection{Heated Duct to the TRC}

A prototype heated inconel duct enables flow of off-gas from the melter to the TRC. This $79 \mathrm{~cm}(31$ in) long, $7 \mathrm{~cm}$ (2.8 inch) inside diameter duct is angled at 45 degrees from horizontal, and heated using a high-temperature electric resistance heating element to heat the duct wall up to $800^{\circ} \mathrm{C}$ if desired. The inside volume of this duct is about $2,910 \mathrm{~cm}^{3}\left(177 \mathrm{in}^{3}\right)$, about $16 \%$ of the total freeboard volume of the melter, lid, and duct. 


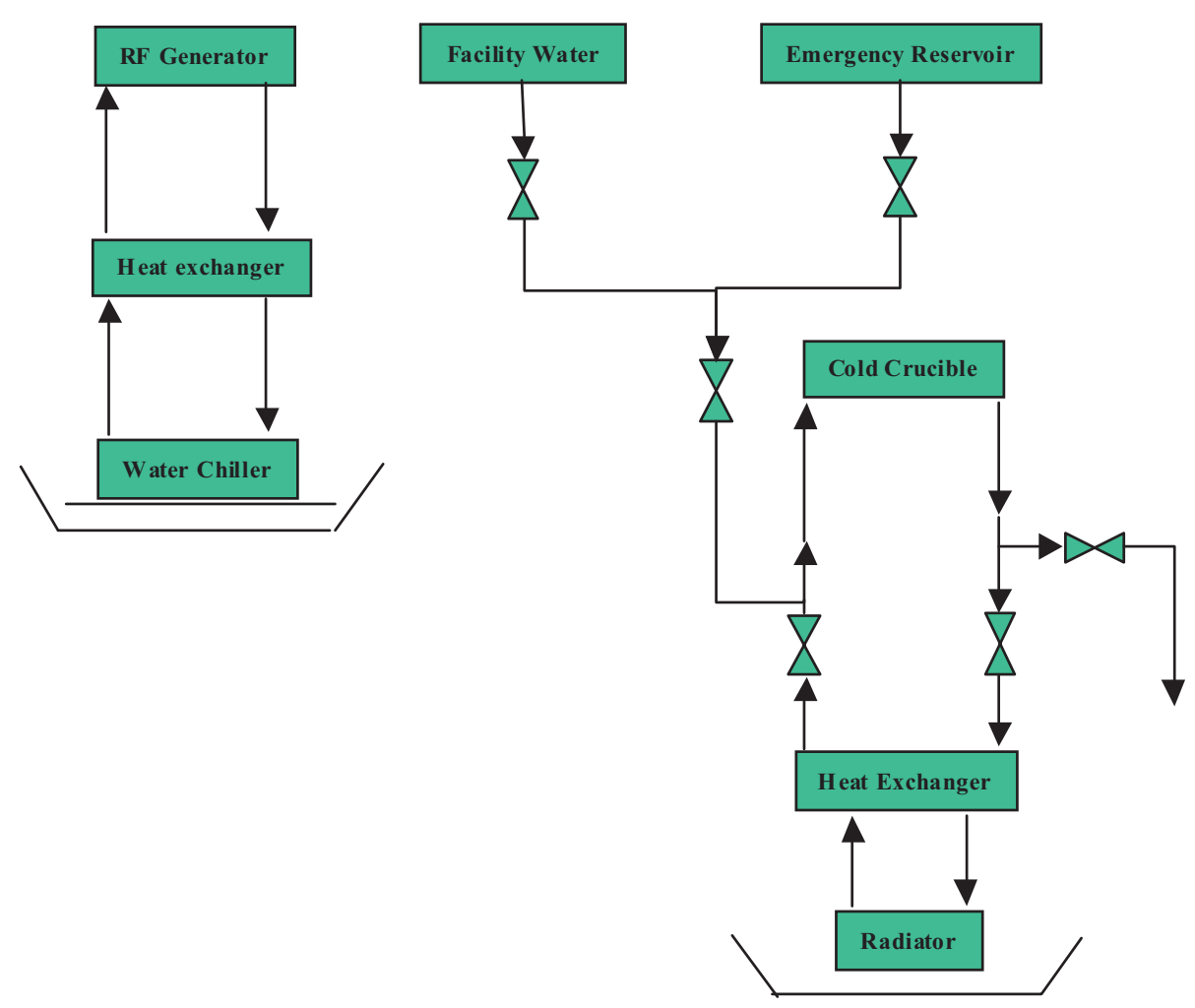

Figure 3-3. INL CCIM cooling water system schematic.

This duct is designed to minimize gas condensation and particulate deposition, and, if heated hot enough, will encourage particulate deposits, if they form over time during operation, to melt and drain back into the melter. An observation/cleanout port is located in the wall of the TRC opposite the end of this duct, to enable monitoring and cleanout of this duct, if necessary, during operation.

This duct can be operated with the heater off, if desired, to avoid heating the off-gas and better emulate the process gas time-temperature history of larger CCIM systems. During the OGSE demonstration, this heater was operated at a temperature setpoint of $300^{\circ} \mathrm{C}$ until after the Off-gas Test 1 , when the fuse for the heater failed and the heater was turned off for the rest of the demonstration. This variation in heater temperature did not affect the melter freeboard temperature or impact the partitioning of Cs during the demonstration. Only $1 \%$ of the total output Cs was found in deposits in the melter freeboard and off-gas pipe. Most of those deposits were removed from the melter lid inside surfaces, not the off-gas pipe.

The sample port for collecting process off-gas samples downstream of the melter is located near the outlet of this heated duct, 10 duct diameters downstream of the melter outlet and 1 diameter upstream of the inlet to the TRC, which is a suitable location for isokinetic particulate sampling in small ducts according to US Environmental Protection Agency (EPA) Method 1A ("Sample and Velocity Traverses for Stationary Sources with Small Stacks or Ducts," 40 CFR 60, Appendix A).

Two sample points are available for continuous emissions monitoring system (CEMS) measurements. One location is in the melter freeboard, through a sample tube that extends through the melter freeboard to a location at the inlet to the melter outlet duct. The other CEMS sample point is at the inlet to the TRC. 


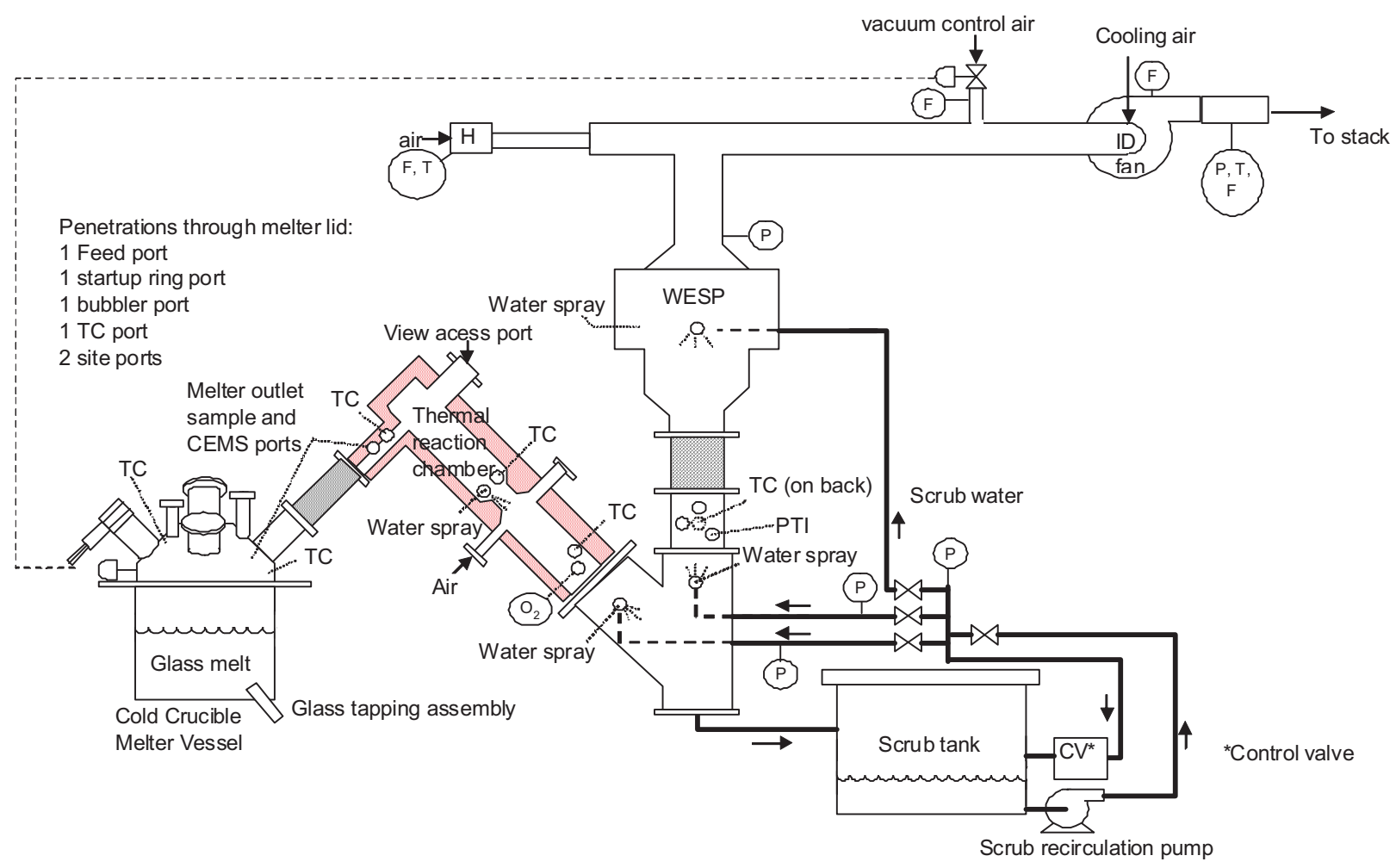

[ccim offgas system design calculations 29 jan 09.x ls]process diagram 4

Figure 3-4. INL CCIM off-gas treatment system.

\subsubsection{Thermal Reaction Chamber}

The TRC is designed to perform nonselective, noncatalytic, thermal $\mathrm{NO}_{\mathrm{x}}$ reduction and also fully oxidize any reduced gas species such as $\mathrm{H}_{2}, \mathrm{CO}$, or $\mathrm{CH}_{4}$. The off-gas can be heated in the first stage using electrical heating to $\mathrm{NO}_{\mathrm{x}}$ reduction reaction temperatures (of around $800-1,000^{\circ} \mathrm{C}$ ) using an electric immersion heater. The immersion heater has a maximum temperature rating of $1,200^{\circ} \mathrm{C}$. The reaction chamber is sized and configured to provide adequate heat transfer surface area, mixing, and residence time to heat and maintain the gas at the design temperature for at least 2-seconds residence time. $\mathrm{NO}_{\mathrm{x}}$ destruction was not an objective of the OGSE demonstration, and so this chamber, while heated to a nominal temperature of up to $500^{\circ} \mathrm{C}$, was not operated for $\mathrm{NO}_{\mathrm{x}}$ destruction.

The second stage of the TRC provides the capability of evaporative cooling of a water spray into the off-gas to cool the $\mathrm{NO}_{\mathrm{x}}$-reduced off-gas to about $800^{\circ} \mathrm{C}$, if the TRC is operated in the $\mathrm{NO}_{\mathrm{x}}$-reduction mode. This was not needed and not used in the OGSE demonstration.

In the oxidizer section, air is normally added to provide oxygen for complete oxidation of $\mathrm{CO}$ and other products of incomplete combustion (PICs) that were formed or remain in the reducing section off-gas. The oxidizer section is designed consistent with typical efficient thermal oxidizer designs, with a residence time of at least 2 seconds. The temperature is controlled to avoid exceeding about $1,000^{\circ} \mathrm{C}$ by the water spray in stage two, to avoid excessive thermal $\mathrm{NO}_{\mathrm{x}}$ formation that could occur if temperatures significantly exceeded $1,000^{\circ} \mathrm{C}$. This was not used in the OGSE demonstration runs. 


\subsubsection{Off-gas Quench Section}

Following thermal oxidation the off-gas is cooled (quenched) by water spray evaporation to the adiabatic dewpoint of the off-gas with the added evaporated water. This section is constructed of Hastelloy steel to tolerate the initially high off-gas temperature and to provide good resistance to corrosion at both high and low temperatures.

\subsubsection{Wet Scrubber System}

Immediately following the temperature quench stage, the off-gas passes through a wet scrubber designed to remove acid gases and some of the residual particulate matter. The scrubber system includes the high performance scrubber itself, the scrub tank that collects and holds scrub solution, and the scrub solution recirculation system. The recirculation system includes a pump, valves, and piping to recirculate scrub solution to the spray quench nozzles in the off-gas quench section, and to the scrubber.

The scrubber is a wet electrostatic precipitator (WESP). The WESP uses electrical energy to charge entrained particulate matter and condensed water droplets, causing them to migrate to the collector walls. The WESP is self-cleaning. The electrodes are electrically isolated from the collectors, and purged with a dry air flowrate to prevent moisture condensation at this location. The WESP was not powered during the OGSE demonstration, because high performance particulate removal was not required to meet demonstration objectives, or for compliance to the air permit exemption. The water quench and scrubber recycle system was operated, to ensure that the melter off-gas was cooled before passing downstream of the scrubber.

\subsubsection{Induced Draft Fan}

The induced draft (ID) fan provides the motive force to draw the off-gas from the melter through the off-gas system. Since off-gas flowrates may vary widely under different operating conditions, a vacuum control system is used upstream of the constant-speed ID fan. This system includes flow control dampers and an ambient air dilution system that is automatically controlled based on the continuously-measured melter vacuum and the melter vacuum setpoint.

\subsection{PROCESS MONITORING AND CONTROL SYSTEM}

The CCIM demonstration system is continuously monitored and controlled using a computer-based data acquisition and control system (DACS). The system includes a control computer, LabVIEW software, process and instrumentation diagram (P\&ID) displays, the Instrument Interface, plant instruments, the Control Interface, plant controls, and a video monitoring system. Key parameters for all subsystems are continuously monitored and controlled. Parameters that are continuously measured and recorded include temperatures, pressures, voltages, power levels, flowrates, and off-gas composition.

The CEMS is a component of the process monitoring and control system. The CEMS continuously samples and analyses the off-gas. The CEMS sampled from two locations, the freeboard of the melter and at a location near the outlet of the melter off-gas pipe (the same sample port used for the summa canister TO-14 and the EPA Method 5/29 measurements. The sample tube for the melter freeboard location penetrated through the freeboard to a location near the inlet of the melter off-gas pipe. Comparisons of the CEMS data from the two locations showed that there were no significant differences in the gas concentrations measured at the two locations. The CEMS data reported here, for the same time periods as the off-gas Method 29 metals emissions sample periods, were obtained from the melter freeboard location. 
The CEMS includes a heated sample probe, heated sample line, heated filter, gas chiller, sample pump, gas distribution system to the analyzers, the analyzers, a calibration gas system, and data linking so the CEMS data are continuously, automatically, electronically logged.

All CEMS data were determined on a dry basis, after condensation of moisture from the sample gas.

All components downstream of the sample gas chiller system are unheated because condensable moisture is removed in the chiller. The sample pump induces the negative pressure needed to draw the sample gas from the off-gas pipe into the CEMS. A backup filter located immediately downstream of the sample pump provides added protection for the flow meters and analyzers from particulate matter damage or fouling.

Total hydrocarbon (THC) analysis is made by flame ionization detection of carbon ions that are produced when hydrocarbon compounds are ionized at high temperatures in a hydrogen-air flame. The Method 25A procedure was modified to allow for chilling and condensation of the sample gas upstream of the THC analyzer. Condensate samples were collected for analysis if there was concern about condensation of hydrocarbons that could then bias the THC measurement. When the $\mathrm{THC}$ and $\mathrm{CH}_{4}$ data, and inspections of the condensate, showed that any hydrocarbon condensation was minimal, then it was determined to not analyze the CEMS condensate samples and accept the THC data without any correction. This determination is consistent with similar results from other demonstration programs, where the CEMS condensate was analyzed for THC, and THC levels in the CEMS condensate were typically low or not detectable.

The components of the sample pump, and all other components of the CEMS that contact the sample gas, are constructed of stainless steel, Teflon, glass, or other materials designed to avoid reaction with the sample gas.

The CEMS analyzers were calibrated daily with calibration gases. Any CEMS data that were obtained during time periods when the zero and span calibration error exceeded specifications in EPA Methods 3A, 7E, 10, and 25A was corrected for calibration error.

\section{DEMONSTRATION METHODOLOGY}

Demonstration runs were performed to accomplish the demonstration objectives described in the demonstration plan (Soelberg 2009). Process conditions were automatically and manually controlled to maintain stable conditions at each run condition. The demonstration system was operated at selected operating conditions, while data were continuously, electronically logged, and also manually recorded onto data sheets. Samples from process input and output streams were collected for analysis. Two different demonstration runs were performed:

- An initial parametric evaluation of operating conditions was performed during December 18-19, 2008 to enable the operators to determine how to operate each subsystem within target ranges, and in some cases determine what those ranges are. Results of this parametric demonstration are not included in this report.

- Following the initial parametric evaluation, a selected number of operating conditions was defined for longer-term operation, process measurements, and process sampling to meet demonstration objectives during the OGSE demonstration. The OGSE demonstration was performed during January 19-21, 2009.

The OGSE demonstration included sample collection for analysis of all input and output streams, so that laboratory analyses and mass balances could be used to determine the fate of feed constituents, especially Cs: 
- Simulant feed

- Product glass

- Material recovered from the melter freeboard, lid, and off-gas pipe after the demonstration

- Off-gas and particulate matter entrained in the off-gas

The off-gas was continuously monitored using a CEMS for $\mathrm{O}_{2}, \mathrm{CO}_{2}, \mathrm{H}_{2}, \mathrm{CO}, \mathrm{CH}_{4}, \mathrm{THC}$, and $\mathrm{NO}_{\mathrm{x}}$. The off-gas samples included EPA Method 29 for metals including Cs) and total particulate matter emissions, and EPA Method TO-14 for redundant $\mathrm{H}_{2}$ and $\mathrm{CH}_{4}$ measurement, and measuring speciated volatile organic compound (VOC) emissions. EPA Method 29 was performed isokinetically, and also measured off-gas velocity, flowrate, and $\mathrm{H}_{2} \mathrm{O}$ concentration.

\subsection{CCIM Demonstration System Startup}

The demonstration system startup included the following components:

- Complete pre-start procedure (make ready and power-on all subsystems per the startup sequence).

- Ensure that the feed tank is well stirred and circulated to suspend frit and UDS.

- Add start up glass and starting media to the crucible.

- Start all subsystems in the proper sequence (cooling systems, induction power generator, TRC, wet scrubber, and ID fan) according to startup procedures.

- As the startup glass heats in the crucible, make adjustments to tune the induction power as needed for heatup. Monitor all other system parameters, especially the cooling systems.

- When the glass in the crucible is molten and has reached the target melt temperature, and other subsystems (cooling systems, TRC, wet scrubber, and ID fan) are operating within their startup parameters, then the melter is ready to start simulant feed.

- Start simulant feed following the simulant startup checklist, which includes verification/ adjustment of all system operating conditions prior to starting simulant feed.

- Adjust melter power levels, cooling system flowrates, and off-gas system parameters to reach and stabilize operation at the target operating conditions.

\subsection{OGSE Demonstration System Operation}

The demonstration system was operated to accomplish the demonstration objectives. Process conditions were either automatically or manually controlled to maintain stable conditions at each demonstration condition.

The scope of the demonstration included operating the demonstration system at selected operating conditions, while recording data that are continuously, electronically logged, and also manually recorded onto data sheets. The scope also included collection and analysis of samples from process input and output streams for selected demonstration conditions, and post-demonstration cleanout, inspection, and sampling.

When the melt level was high enough to start glass pouring, at any time during this demonstration, glass pouring was initiated. Glass pouring was periodic, not continuous, starting and stopping to maintain the melt height within acceptable limits in the melter. 


\section{FEED SIMULANT}

Approximately 137 million L (36 million gallons) of HLW is stored in underground tanks at the SRS. These wastes are from spent nuclear fuel and target treatment, and contain dissolved salt (dissolved solids) and $8 \%$ undissolved sludge in an alkaline solution which consists mainly of metal hydroxides (mostly Fe, Al, Mn, and Ni). This sludge is the waste that is being processed in the DWPF. Sludge Batch 4 (SB4), which is a sludge waste with a high aluminum content resulting from the H-Area modified (HM) process, was processed at DWPF until October 2008.

The simulant feed for the OGSE demonstration was designed to represent the SB4 DWPF feed pretreated by the addition of formic acid. The simulant used in this demonstration (shown in Table 5-1) is from Batch 1 of a total of four batches of simulant prepared by Harrell Industries. The simulant fabrication process replicated the DWPF Sludge Receipt and Adjustment Tank (SRAT) process, and so was called SRAT simulant until modified to include added frit, a Cs spike, and rinse water. No radioactive elements are included in this simulant. Lead, a trace-level hazardous metal, has also been excluded, although hazardous metals $\mathrm{Cr}$ and $\mathrm{Ni}$ are included. These elements are known to potentially contribute to the formation of spinel crystals within the glass; thus, it was important for this demonstration that they be included in the simulant.

Glass frit 503-R6 was mixed with the simulant to achieve a waste loading of 46\% weight percent of oxides from the waste simulant in the product glass (Marra 2008a). The remaining $54 \mathrm{wt} \%$ of the glass is from the added frit. The frit composition (shown in Table 5-2) was tailored to provide the desired concentrations of $\mathrm{B}, \mathrm{Li}, \mathrm{Na}$, and $\mathrm{Si}$ in the glass. This table shows that the measured concentration of the frit was close to the target composition, with low levels of impurities. The highest concentration impurity was $\mathrm{Al}_{2} \mathrm{O}_{3}$, which is already a major constituent in the simulant, and therefore not significantly affected by the impurity in the frit. Excess $\mathrm{Al}_{2} \mathrm{O}_{3}$ may cause nepheline precipitation, which is detrimental to glass quality. Some verification melts were then performed at the SRNL to ensure that the targeted waste loading of $46 \%$ was actually still acceptable.

The goal of the frit composition and waste loading is to (a) produce a glass with acceptable waste form performance, with minimal nepheline formation [with a nepheline discriminator value $\mathrm{SiO}_{2} /\left(\mathrm{SiO}_{2}+\mathrm{Na}_{2} \mathrm{O}+\mathrm{Al}_{2} \mathrm{O}_{3}\right)>0.62$, where the chemical formulae represent weight percent values of that oxide in the glass], and (b) suitable melter operability, with a liquidus temperature at least $50^{\circ} \mathrm{C}$ less than the planned melter operating temperature to minimize spinel formation in the melter (Marra 2008b).

Nonradioactive $\mathrm{Cs}$ (in the form of $\mathrm{CsNO}_{3}$ ) was spiked into the simulant as surrogate for radioactive Cs. The target concentration for this $\mathrm{Cs}_{2} \mathrm{O}$ in the product glass was $0.5 \mathrm{wt} \%$. However, a lesser amount of Cs was spiked, due to a calculation error, resulting in a lower concentration of $\mathrm{Cs}_{2} \mathrm{O}$ in the glass that averaged $0.30 \mathrm{wt} \%$, after a portion of the Cs evolved to the off-gas.

Table 5-3 shows the calculated and measured composition of the simulant that was fed during the OGSE demonstration. This composition is different from that shown in Table 5-1 because (a) the concentrations are normalized to slurry basis instead of a calcined solids basis, (b) the composition includes the glass frit, (c) the composition includes the Cs spike, and (d) the slurry has been diluted about 16 volume $\%$ by the addition of water used to rinse the feed drums during transfer to the feed system, and to rinse the feed system equipment during feed system startup and checkout. 
Table 5-1. Sludge Batch 4 waste simulant, fabricated by Harrell Industries, Inc., analytical results (Tchemitcheff 2009).

\begin{tabular}{|c|c|c|c|c|}
\hline & Batch 1 & Batch 2 & Batch 3 & Batch 4 \\
\hline \multicolumn{5}{|c|}{ Elemental wt \% - Calcined at 1,100 deg C } \\
\hline Al & 14.7 & 14.5 & 12.6 & 15.2 \\
\hline $\mathrm{Ba}$ & 0.07 & 0.07 & 0.06 & 0.0777 \\
\hline $\mathrm{Ca}$ & 2.49 & 2.62 & 2.51 & 2.09 \\
\hline $\mathrm{Ce}$ & $<0.100$ & $<0.100$ & $<0.100$ & $<0.100$ \\
\hline $\mathrm{Cr}$ & 0.1 & 0.1 & 0.1 & 0.1 \\
\hline $\mathrm{Cu}$ & $<0.100$ & 0.031 & 0.022 & 0.031 \\
\hline $\mathrm{Fe}$ & 23.3 & 20.3 & 20.0 & 22.1 \\
\hline $\mathrm{K}$ & $<0.100$ & 0.062 & 0.082 & 0.068 \\
\hline $\mathrm{Mg}$ & 2.59 & 3.32 & 3.12 & 2.73 \\
\hline $\mathrm{Mn}$ & 5.0 & 4.6 & 4.9 & 4.9 \\
\hline $\mathrm{Na}$ & 13.1 & 14.9 & 17.2 & 12.9 \\
\hline $\mathrm{Ni}$ & 1.11 & 1.29 & 1.27 & 1.42 \\
\hline $\mathrm{P}$ & 0.018 & 0.013 & 0.012 & 0.012 \\
\hline $\mathrm{S}$ & 0.273 & 0.316 & 0.356 & 0.280 \\
\hline $\mathrm{Si}$ & 1.13 & 1.36 & 1.14 & 1.40 \\
\hline $\mathrm{Ti}$ & $<0.100$ & $<0.100$ & $<0.100$ & $<0.100$ \\
\hline $\mathrm{Zn}$ & 0.0455 & 0.0435 & 0.0413 & 0.0457 \\
\hline $\mathrm{Zr}$ & 0.0685 & 0.0644 & 0.0604 & 0.0648 \\
\hline \multicolumn{5}{|c|}{ Anions - mg/kg slurry } \\
\hline $\mathrm{F}$ & $<100$ & $<100$ & $<100$ & $<100$ \\
\hline $\mathrm{Cl}$ & 6,100 & 6,670 & 6,920 & 6,220 \\
\hline $\mathrm{NO}_{2}$ & 6,130 & 6,160 & 2,600 & 2,870 \\
\hline $\mathrm{NO}_{3}$ & 38,200 & 35,000 & 44,600 & 33,700 \\
\hline $\mathrm{PO}_{4}$ & $<100$ & $<100$ & $<100$ & $<100$ \\
\hline $\mathrm{HCO}_{2}$ & 69,800 & 71,000 & 74,100 & 70,000 \\
\hline $\mathrm{SO}_{4}$ & 1,040 & 1,330 & 1,550 & 1,110 \\
\hline $\mathrm{C}_{2} \mathrm{O}_{4}$ & $<100$ & $<100$ & $<100$ & $<100$ \\
\hline \multicolumn{5}{|c|}{ Solids - wt \% } \\
\hline Total & 37.4 & 35.5 & 34.8 & 37 \\
\hline Insoluble & 20.6 & 18.6 & 16.3 & 20.6 \\
\hline Soluble & 16.8 & 16.9 & 18.5 & 16.4 \\
\hline Calcined & 22.9 & 21.3 & 20 & 22.7 \\
\hline $\mathrm{pH}$ & 6.7 & 6.95 & 6.62 & 6.5 \\
\hline $\begin{array}{c}\text { Density } \\
(\mathrm{g} / \mathrm{ml})\end{array}$ & 1.30 & 1.28 & 1.27 & 1.30 \\
\hline
\end{tabular}

Table 5-3 shows that the measured composition of the simulant was close to the target calculated composition. The relative percent difference between the average measured values and the target values was less than $20 \%$ for most of the parameters, within reasonable experimental and analytical error, with a few exceptions. These exceptions occurred for feed constituents for which the target feed concentrations were less than $1 \mathrm{gm} / \mathrm{L}\left(\mathrm{Cr}, \mathrm{Cs}, \mathrm{K}, \mathrm{P}, \mathrm{Ti}\right.$, and $\left.\mathrm{SO}_{4}\right)$. The measured values for these species ranged higher than the target values. The higher measured values may be due to contamination in the process, which would be less significant if the target concentrations were higher. These variations do not cause the feed simulant to be non-representative of the DWPF SB4 feed. 
Table 5-2. Glass frit 503-R6 analytical results (Tchemitcheff 2009).

\begin{tabular}{|c|c|c|c|c|c|}
\hline Oxide & $\begin{array}{l}\text { Target, } \\
\text { wt } \%\end{array}$ & $\begin{array}{c}1^{\text {st }} \text { Sample, } 1^{\text {st }} \\
\text { Analyses, } \\
\text { wt } \%\end{array}$ & $\begin{array}{c}1^{\text {st }} \text { Sample, } 2^{\text {nd }} \\
\text { Analyses, } \\
\text { wt } \%\end{array}$ & $\begin{array}{c}2^{\text {nd }} \text { Sample, } \\
1 \text { st Analyses, } \\
\text { wt } \%\end{array}$ & $\begin{array}{c}\text { Average, } \\
\text { wt } \%\end{array}$ \\
\hline $\mathrm{B}_{2} \mathrm{O}_{3}$ & 14 & 13.37 & 13.10 & 13.03 & 13.17 \\
\hline $\mathrm{Na}_{2} \mathrm{O}$ & 3 & 3.79 & 3.87 & 3.78 & 3.81 \\
\hline $\mathrm{Li}_{2} \mathrm{O}$ & 9 & 8.67 & 8.53 & 8.50 & 8.57 \\
\hline $\mathrm{SiO}_{2}$ & 74 & 72.76 & 73.06 & 73.30 & 73.04 \\
\hline \multicolumn{2}{|c|}{ Impurities (total) } & 1.41 & 1.44 & 1.39 & 1.41 \\
\hline \multicolumn{2}{|c|}{$\mathrm{Al}_{2} \mathrm{O}_{3}$} & 1.06 & 1.09 & 1.05 & 1.07 \\
\hline \multicolumn{2}{|l|}{$\mathrm{CaO}$} & 0.15 & 0.15 & 0.16 & 0.15 \\
\hline \multicolumn{2}{|l|}{$\mathrm{Cr}_{2} \mathrm{O}_{3}$} & 0.02 & - & - & - \\
\hline \multicolumn{2}{|l|}{$\mathrm{Fe}_{2} \mathrm{O}_{3}$} & 0.11 & 0.12 & 0.10 & 0.11 \\
\hline \multicolumn{2}{|l|}{$\mathrm{MgO}$} & 0.02 & 0.02 & 0.02 & 0.02 \\
\hline \multicolumn{2}{|l|}{$\mathrm{TiO}_{2}$} & 0.05 & 0.06 & 0.06 & 0.06 \\
\hline Grand Tot & 100 & 100.00 & 100.00 & 100.00 & 100.00 \\
\hline
\end{tabular}

Melter startup glass frit was prepared and provided for the demonstration so that the startup glass had a composition similar to the intended product glass from the OGSE demonstration. The composition of the startup glass is shown in Table 5-4. Cs in the form of $\mathrm{CsNO}_{3}$ was also spiked into the starting glass added to the melter prior to the demonstration, so that the Cs concentration in the starting glass was about the same (about $0.3 \mathrm{wt} \%$ ) as in the product glass from the simulant feed. 


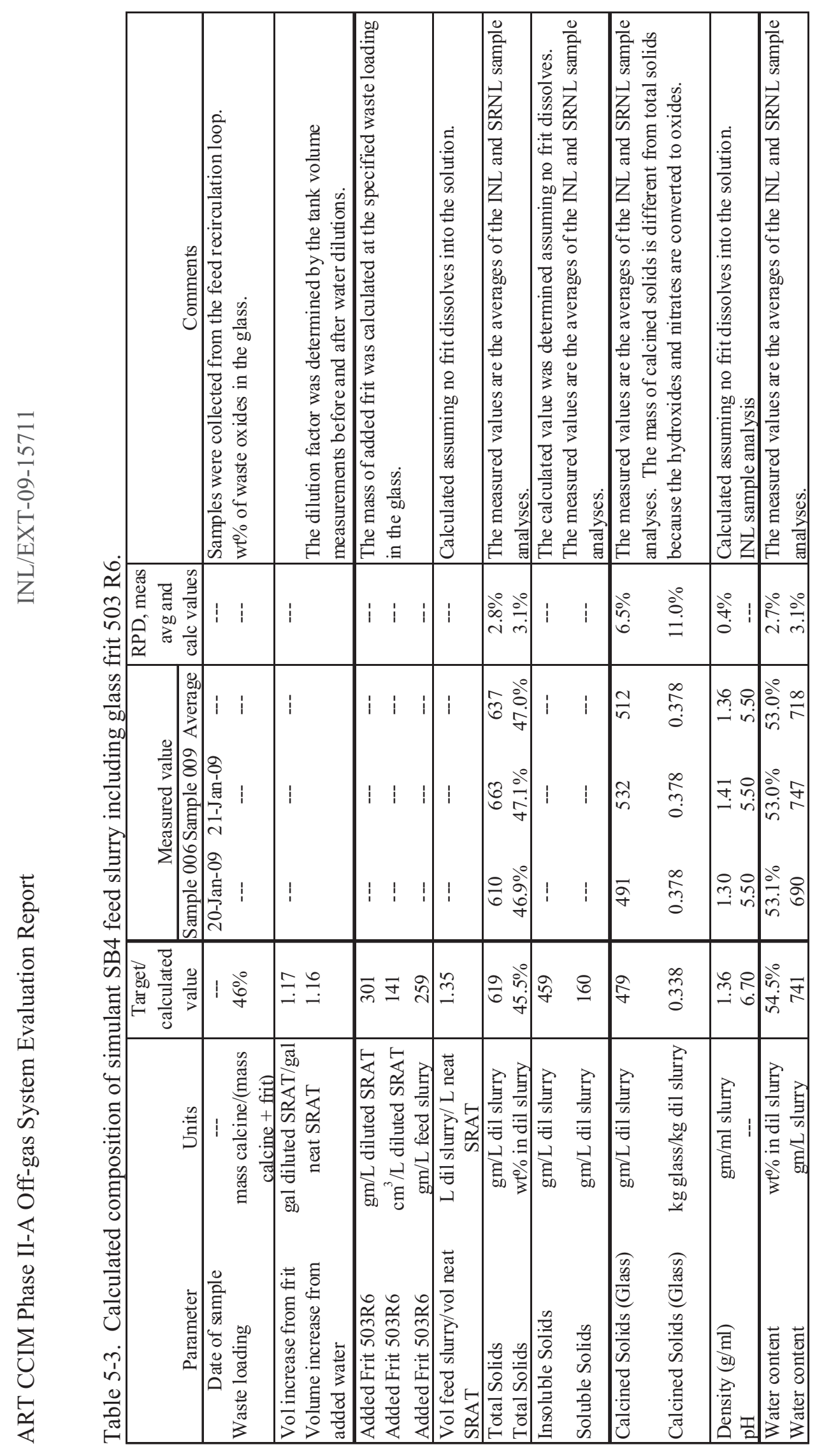




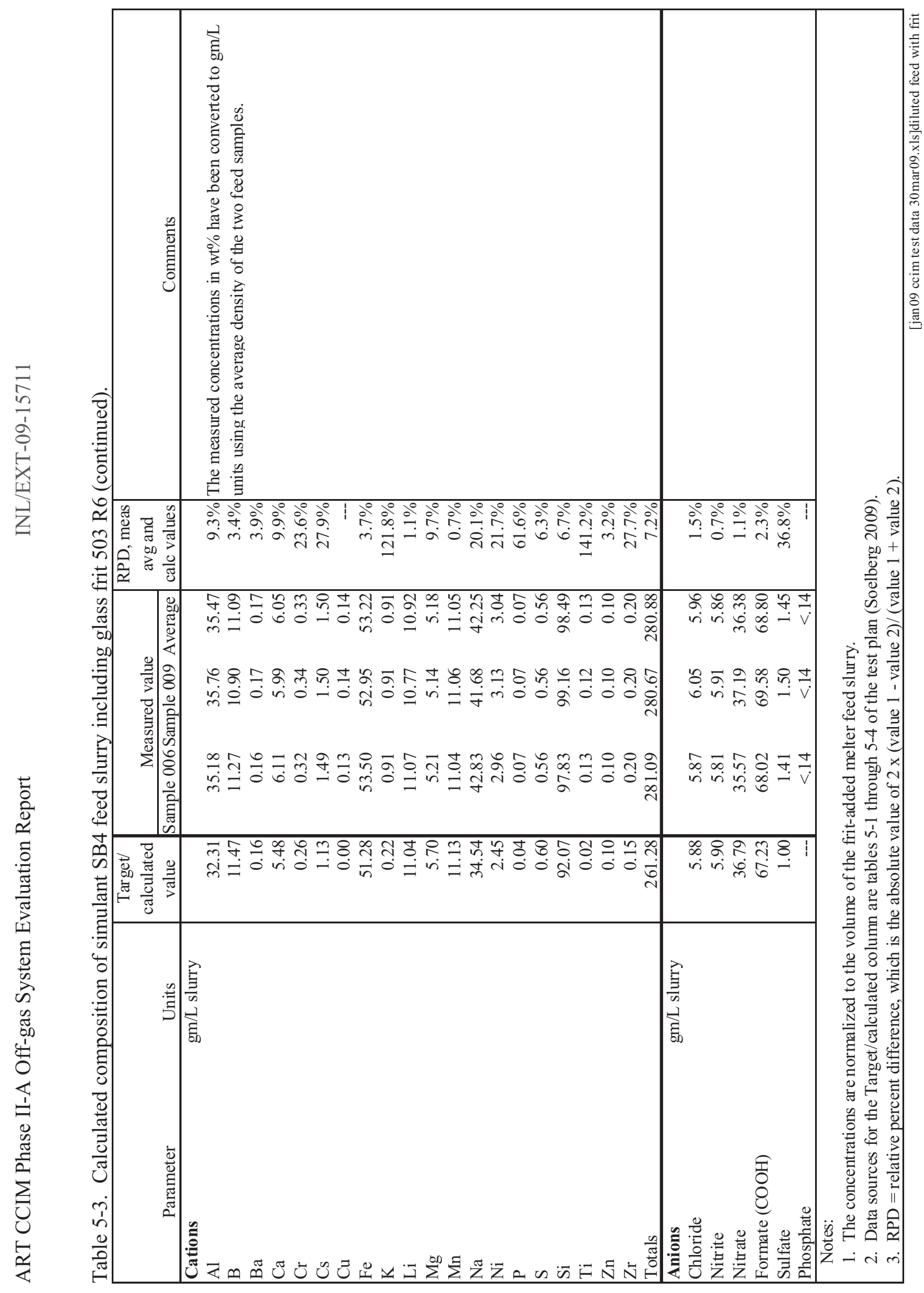


Table 5-4. Startup glass (503-R6/SB4 at $46 \mathrm{wt} \%$ waste loading) analytical results (Tchemitcheff 2009).

\begin{tabular}{|crr|}
\hline Oxide & \multicolumn{1}{c}{ Target, } \\
wt $\%$ & $\begin{array}{c}2^{\text {nd }} \\
\text { Sample, } \\
\text { wt } \%\end{array}$ \\
\hline $\mathrm{Al}_{2} \mathrm{O}_{3}$ & $12.96 \pm 1.0$ & 13.1 \\
$\mathrm{~B}_{2} \mathrm{O}_{3}$ & $7.56 \pm 0.8$ & 7.03 \\
$\mathrm{BaO}$ & $0.02-0.1$ & 0.00 \\
$\mathrm{CaO}$ & $1.40 \pm 0.5$ & 1.39 \\
$\mathrm{Ce}_{2} \mathrm{O}_{3}$ & $0.05-0.15$ & 0.00 \\
$\mathrm{Cr}_{2} \mathrm{O}_{3}$ & $0.05-0.15$ & 0.021 \\
$\mathrm{CuO}$ & $0.02-0.1$ & 0.035 \\
$\mathrm{Fe}_{2} \mathrm{O}_{3}$ & $14.74 \pm 1.0$ & 13.0 \\
$\mathrm{~K}_{2} \mathrm{O}$ & $0.02-0.1$ & 0.103 \\
$\mathrm{Li}_{2} \mathrm{O}$ & $4.86 \pm 0.5$ & 5.20 \\
$\mathrm{MgO}$ & $1.41 \pm 0.5$ & 0.927 \\
$\mathrm{MnO}$ & $2.94 \pm 0.5$ & 3.01 \\
$\mathrm{Na}_{2} \mathrm{O}$ & $11.13 \pm 1.0$ & 11.2 \\
$\mathrm{NiO}$ & $0.5-1.0$ & 0.586 \\
$\mathrm{SO}$ & $0.2-0.8$ & 0.098 \\
$\mathrm{SiO}_{2}$ & $41.34 \pm 2.0$ & 43.7 \\
$\mathrm{ZnO}$ & $0.02-1.0$ & 0.03 \\
$\mathrm{ZrO}_{2}$ & $0.02-1.0$ & 0.476 \\
$\mathrm{PbO}_{\mathrm{Total}}$ & --- & 0.015 \\
& & 99.9 \\
\hline
\end{tabular}

\section{DEMONSTRATION RESULTS}

Figure 6-1 shows a summary of the OGSE temperatures and power levels. The system was operated continuously over a time period of about 58 hours. Starting glass, manually added to the crucible prior to the demonstration, became essentially completely molten and reached the target operating temperature of about $1,250^{\circ} \mathrm{C}$ in about 3 hours after induction power startup. The induction power system was operated at a frequency of about $1.7 \mathrm{MHz}$, which was close to the target of 1.6 MHz needed for representative scaling to the larger melter at Marcoule.

As shown in Figure 6-2, simulant feed was started at 3.75 hours, and continued for a total of about 52 hours. The simulant feedrate was varied from $1.0-4.5 \mathrm{~kg} / \mathrm{hr}$.

Three demonstration conditions were performed per the demonstration plan:

1. Essentially complete cold cap, nominal $1,250^{\circ} \mathrm{C}$ melt temperature, simulant feedrate nominally $3.8 \mathrm{~kg} / \mathrm{hr}$ (resulting in a glass feedrate of $1.45 \mathrm{~kg} / \mathrm{hr}$ ).

2. Less complete cold cap, nominal $1,250^{\circ} \mathrm{C}$ melt temperature, simulant feedrate at nominally $2.3 \mathrm{~kg} / \mathrm{hr}$ $(0.86 \mathrm{~kg} / \mathrm{hr}$ glass, a lower feedrate to enable less complete cold cap coverage).

3. Essentially complete cold cap, nominal $1,300^{\circ} \mathrm{C}$ melt temperature, simulant feedrate at $4.1 \mathrm{~kg} / \mathrm{hr}(1.58$ $\mathrm{kg} / \mathrm{hr}$ glass, slightly higher feedrate to maintain cold cap at the higher melt temperature). 

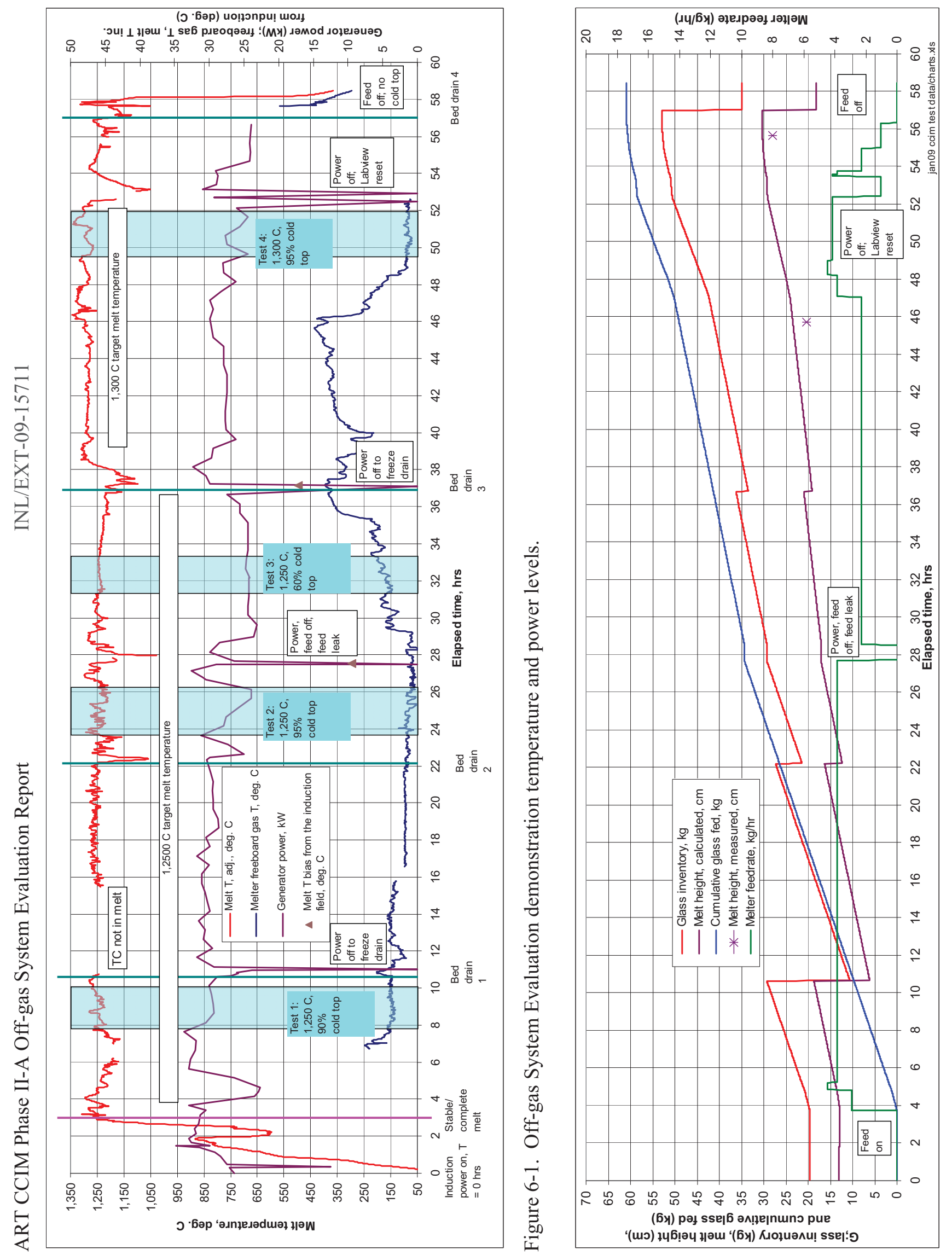

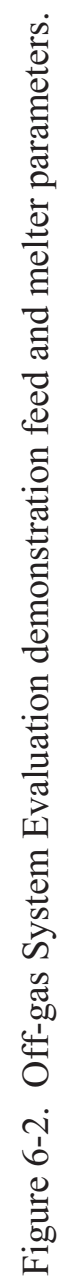


Off-gas sampling and continuous off-gas concentration monitoring were performed for each of these demonstration conditions. Two sets of off-gas samples were collected for the first demonstration condition.

The average conditions measured for each off-gas sampling period are shown in Table 6-1. The melt temperature averaged within $11^{\circ} \mathrm{C}$ of the target temperature. The reported melt temperatures have been corrected for a relatively small bias in the temperature measurement caused by the induction field, and average within $11^{\circ} \mathrm{C}$ of the target melt temperatures.

Table 6-1. Melter system conditions during the melter off-gas sampling periods.

\begin{tabular}{|c|c|c|c|c|c|c|c|c|c|c|c|c|c|c|c|}
\hline \multirow[b]{2}{*}{ Test } & \multirow[b]{2}{*}{$\begin{array}{l}\text { Test } \\
\text { Con- } \\
\text { dition } \\
\end{array}$} & \multirow[b]{2}{*}{$\begin{array}{l}\text { Start } \\
\text { COT }\end{array}$} & \multirow[b]{2}{*}{$\begin{array}{l}\text { End } \\
\text { COT }\end{array}$} & \multirow[b]{2}{*}{$\begin{array}{c}\text { Duration, } \\
\text { hrs }\end{array}$} & \multicolumn{6}{|c|}{ Average operating conditions } & \multicolumn{3}{|c|}{ Average generator power } & \multicolumn{2}{|c|}{ Specific feedrate } \\
\hline & & & & & $\begin{array}{l}\text { Melt } \mathrm{T} \text {, } \\
{ }^{\circ} \mathrm{C}\end{array}$ & $\begin{array}{c}\text { Cold top } \\
\text { coverage, } \\
\%\end{array}$ & $\begin{array}{l}\text { Free- } \\
\text { board } \\
\mathrm{T},{ }^{\circ} \mathrm{C} \\
\end{array}$ & $\begin{array}{l}\text { Calc'd } \\
\text { melt } \\
\text { height, } \\
\mathrm{cm}\end{array}$ & $\begin{array}{l}\text { Feed } \\
\text { rate, } \\
\mathrm{kg} / \mathrm{hr}\end{array}$ & $\begin{array}{c}\text { Melter } \\
\text { vacuum, } \\
\text { cm } \mathrm{H}_{2} \mathrm{O}\end{array}$ & $\begin{array}{c}\text { Anode } \\
\text { current, } \\
\text { A }\end{array}$ & $\begin{array}{l}\text { Plate } \\
\text { voltage, } \\
\mathrm{kV}\end{array}$ & $\begin{array}{c}\text { Power, } \\
\text { kW }\end{array}$ & $\begin{array}{c}\mathrm{kg} / \mathrm{hr} / \mathrm{m} 2 \\
\text { surface } \\
\text { area }\end{array}$ & $\begin{array}{c}\mathrm{kg} / \mathrm{hr} / \mathrm{kW} \\
\text { generator } \\
\text { power }\end{array}$ \\
\hline 1 & 1 & 7.91 & 9.87 & & 1,243 & 90 & 146 & 17 & 3.8 & & 5.1 & 6.0 & & 68 & 0.13 \\
\hline 2 & 1 & 23.66 & 26.41 & 2.75 & 1,239 & 95 & 81 & 15 & 3.8 & & & & 27.3 & 68 & 0.14 \\
\hline 3 & 2 & 31.39 & 33.06 & 1.67 & 1,239 & 70 & 168 & 19 & 2.3 & 1.2 & 4.3 & 5.6 & 24.4 & 40 & 0.09 \\
\hline 4 & 3 & 48.65 & 51.91 & 3.26 & 1,294 & 95 & 89 & 27 & 4.2 & 1.8 & 4.5 & 5.9 & 26.4 & 75 & 0.16 \\
\hline \multicolumn{16}{|c|}{$\begin{array}{l}\text { Notes: } \\
\text { 1. COT = Continuous operating time (elapsed time since test start). } \\
\text { 2. The sampling period includes the time during which the Method } 29 \text { metals and particulate sampling train and the TO-14 sample are collected, } \\
\text { and the time between these two sample collection times. } \\
\text { 3. The melt temperature has been corrected for the average amount of bias to the TC reading caused by induction field. } \\
\text { 4. The melter cold top coverage is a subjective estimate made by looking through the site ports. } \\
\text { 5. The melter freeboard temperature TC is shielded from melt top radiation effects. }\end{array}$} \\
\hline
\end{tabular}

[jan 09 ccim test data 30 mar09.xls]test conditions

A total of $161 \mathrm{~kg}$ of feed was processed during the demonstration, producing about $61 \mathrm{~kg}$ of weighed product glass. As the feed was fed to the melter, the glass level increased until a portion of the molten glass was drained from the melter. The glass drain could not be operated continuously because the glass drain rate was higher than the glass feedrate. Four glass drains were performed during the demonstration. Each mass of drained glass was weighed after cooling. Figure 6-3 shows molten glass being drained from the melter. Residual glass that did not drain out at the end of the demonstration was manually removed from the melter and weighed after cooling.

The calculated glass inventory and melt height in the melter ranged between $20-53 \mathrm{~kg}$ and $6-30 \mathrm{~cm}$, respectively. These values increased as feed was continuously fed, and decreased in step changes as glass was drained from the melter. The calculated melt height agreed well (within $2-4 \mathrm{~cm}$ ) with the measured melt height.

\subsection{Simulant Feedrate}

The cold cap coverage was achieved by adjusting the feedrate and melter power levels to obtain the target molten glass temperatures with varying cold cap levels. Figure 6-4 shows that the specific feedrate can be increased with higher cold cap levels. The melter freeboard temperature was sensitive to the extent of cold cap coverage, because the cold cap reduced thermal radiation from the molten glass.

Average simulant feedrates for each demonstration condition ranged between $2.3-4.2 \mathrm{~kg} / \mathrm{hr}(1.7-$ $3.1 \mathrm{~L} / \mathrm{hr})$. The highest feedrate occurred during the Condition 3, which had a nearly-complete $(90 \%)$ cold cap coverage and a high target glass melt temperature $\left(1,300^{\circ} \mathrm{C}\right)$. The lowest feedrate occurred for Condition 2, which has a lower cold cap coverage (about 60\%) at a target melt temperature of $1,250^{\circ} \mathrm{C}$. These feedrates corresponded to specific feedrates that ranged between $40-75 \mathrm{~kg} / \mathrm{hr} / \mathrm{m}^{2}$ melt surface area $(0.09-0.16 \mathrm{~kg} / \mathrm{hr} / \mathrm{kW})$. 


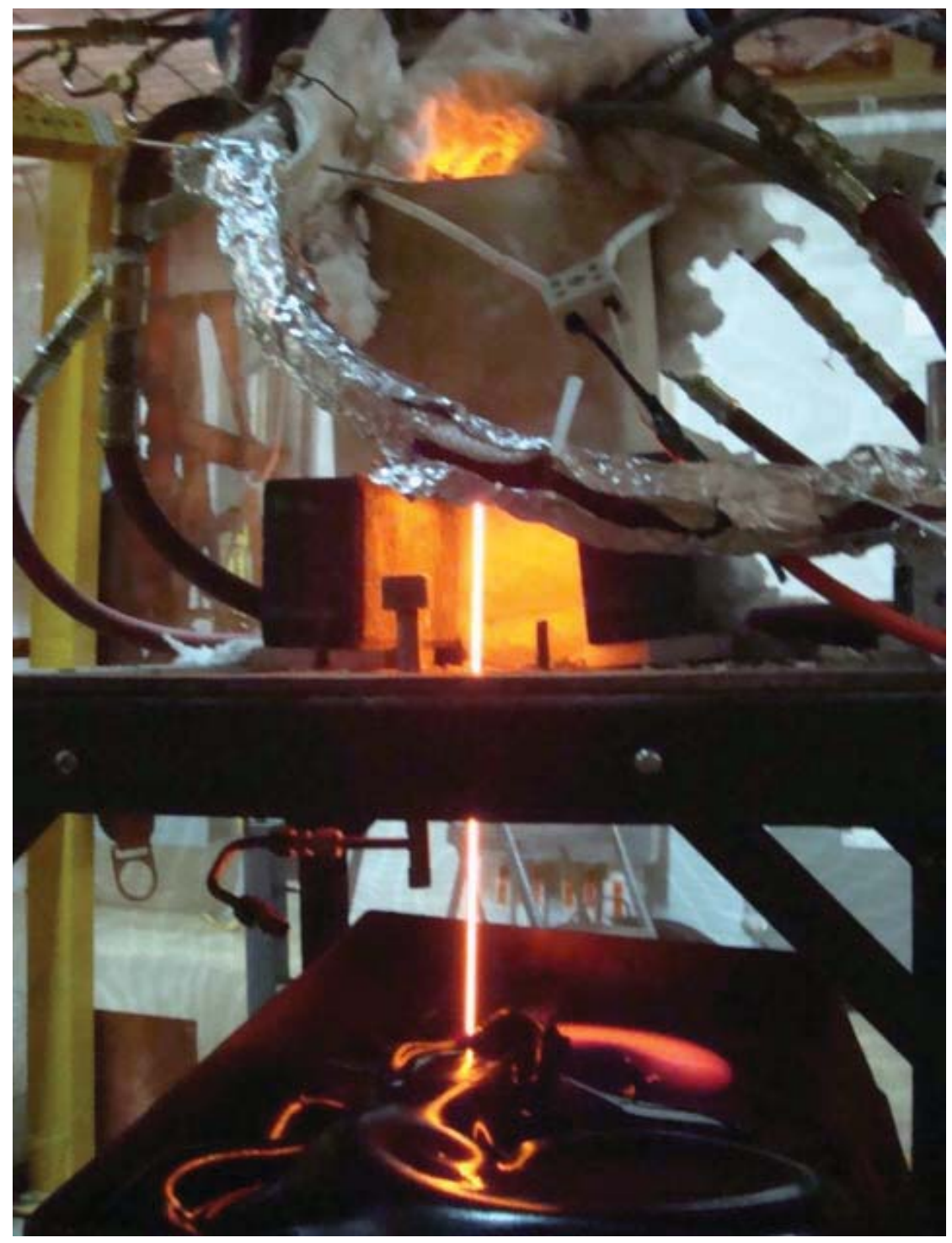

Figure 6-3. Molten glass draining from the melter through the bottom tap hole.

A higher feedrate up to $4.5 \mathrm{~kg} / \mathrm{hr}$ was attempted, but the cold cap depth increased during that time until there was insufficient light inside the melter to see the top of the melt either using the video camera or by visual observations.

Some bridging of unmelted cold cap material also occurred, probably due to the small diameter of the melter and the presence of the melt thermocouple (TC) and the air bubbler that penetrated from the melter lid through the cold cap into the molten melt. The distances from the melter sidewall was about $26.7 \mathrm{~cm}$ (10.5 inches) and the distances between the melter sidewall and the melt thermocouple and air bubbler were even less. The distance between the TC and the air bubbler was $10 \mathrm{~cm}$ (4 inches), and the distance from the air bubbler (and the TC) and the sidewall was $8.4 \mathrm{~cm}$ (3.3 inches). These relatively short distances provide opportunity for a hardened, crusty cold cap to attach to and then bridge between the TC, bubbler, and sidewall. 


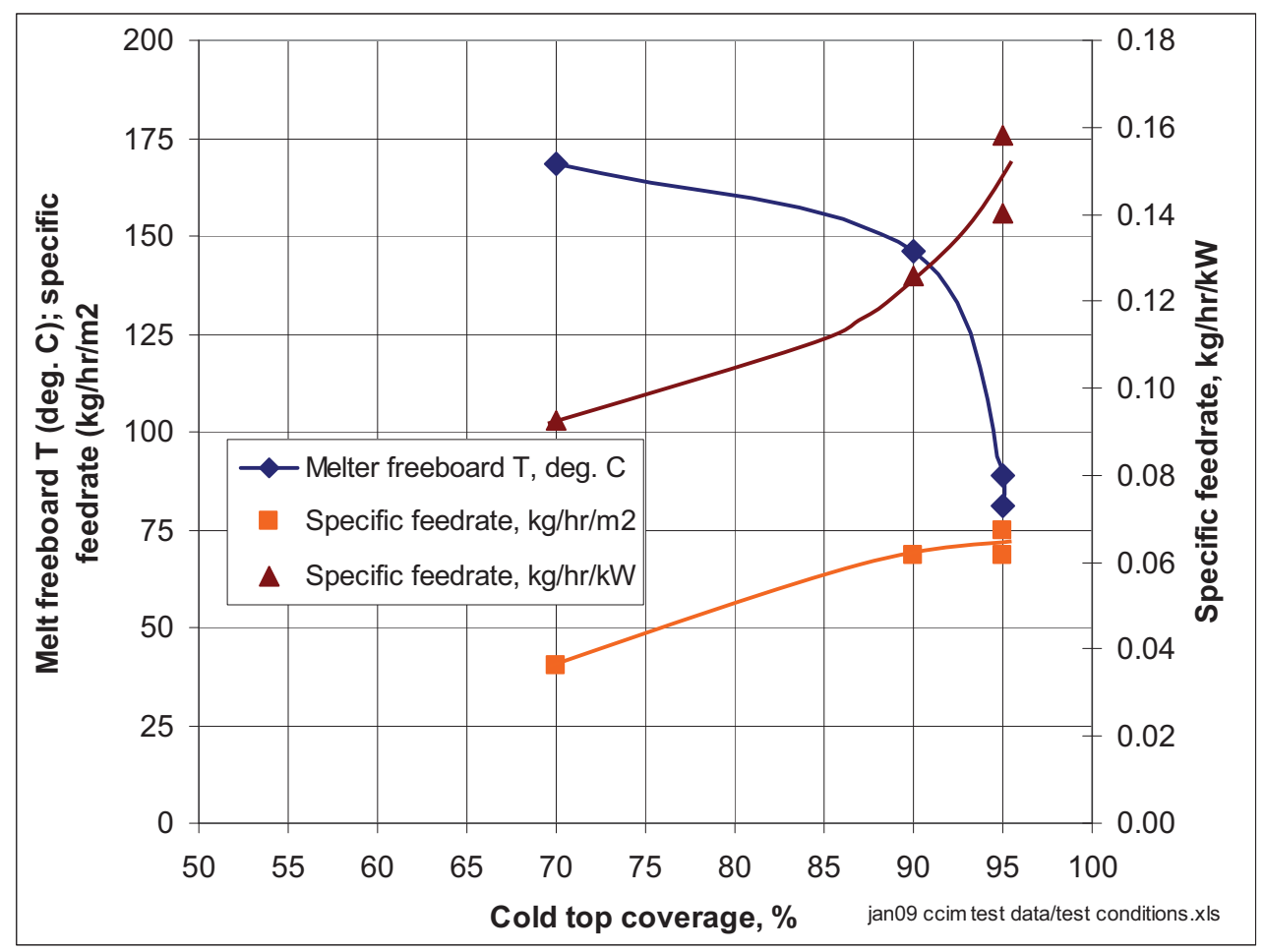

Figure 6-4. Specific feedrate and freeboard temperature for different cold cap coverage levels.

When cold cap bridging occurs, then as the molten glass level drops during a melter drain, an air gap can form between the bottom of the bridge and the top of the molten glass. When this occurs, then heat transfer between the molten glass and the bridge (and additional cold feed on top of the bridge) is significantly reduced. This condition results in a lower possible feedrate than would be achievable without cold cap bridging, and needs to be avoided.

\subsection{Melt Temperature Profile}

The melt temperature was measured using a TC that could be raised or lowered so that it provided a representative melt temperature. Figure 6-5 shows a vertical temperature traverse in the melter from the bottom of the crucible to the top of the melt, when the melt depth was $28 \mathrm{~cm}$. The melt temperature was relatively constant in the melt between the melt bottom up to $12 \mathrm{~cm}$ high $16 \mathrm{~cm}$ below the melt surface). The melt temperature TC was typically $5-8 \mathrm{~cm}$ above the bottom of the melter, at a depth where the melt temperature was fairly constant.

\subsection{Melter Off-gas Emissions}

The off-gas composition and flowrate were measured at the melter outlet (upstream of the heated duct) so that the fate of feed constituents including Cs, other metals, total particulate, nitrite, nitrate, and formate could be determined. The off-gas measurements included:

- Continuous emissions monitoring for $\mathrm{O}_{2}, \mathrm{CO}_{2}, \mathrm{H}_{2}, \mathrm{CO}, \mathrm{CH}_{4}, \mathrm{THC}, \mathrm{NO}$, and $\mathrm{NO}_{\mathrm{x}}$. 


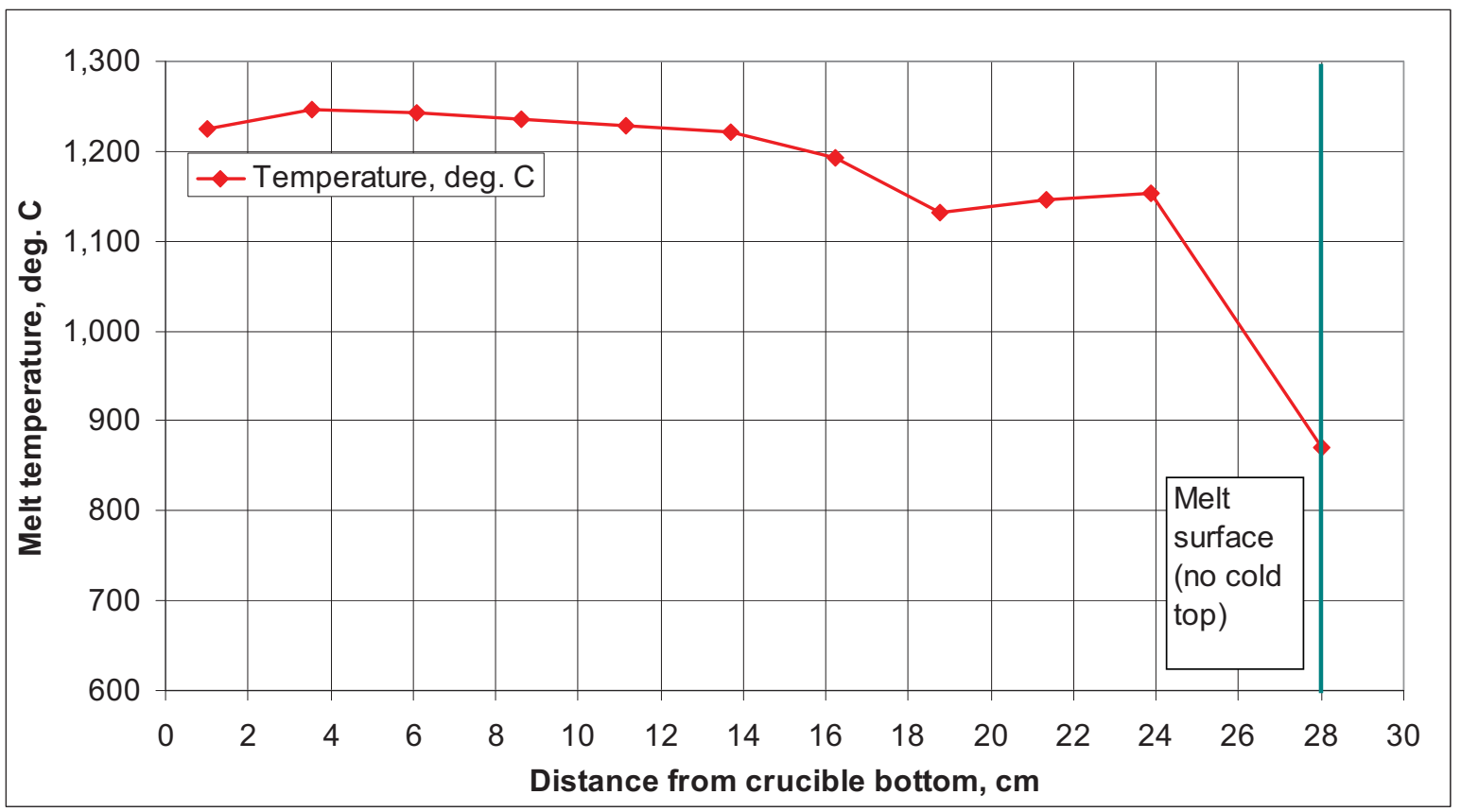

Figure 6-5. Melt temperature vertical traverse.

- Periodic summa canister grab sampling followed by laboratory gas chromatography (GC) and gas chromatography / mass spectroscopy (GC/MS) analysis for $\mathrm{H}_{2}, \mathrm{CH}_{4}$, and VOCs according to EPA Method TO-14, modified to include the $\mathrm{GC}$ analysis for $\mathrm{H}_{2}$ and $\mathrm{CH}_{4}$.

- Periodic melter off-gas velocity and temperature measurements according to EPA Methods 1A and $2 \mathrm{C}$ for sampling in small-diameter ducts.

- Periodic grab sampling for determining particulate matter (PM) and metals emissions according to EPA Methods 5 and 29, modified for sampling in small diameter ducts.

\subsubsection{Melter Off-gas Composition and Flowrate}

Tables 6-2 and 6-3, and Figures 6-6 through 6-9, show the average CEMS data on both the dry, asmeasured basis, and also normalized to a wet basis, for each demonstration condition. The normalization was done using the melter off-gas moisture content determined by the EPA Method 5/29 measurements. Reporting both sets of data is important because, while the as-measured, dry-basis data are used for process monitoring and control, they do not accurately represent the actual melter off-gas composition, which is accurately represented by the wet-basis data. This is important when considering such issues as off-gas flammability and $\mathrm{NO}_{\mathrm{x}}$ concentrations, because the actual concentrations, being on a wet basis, are diluted by moisture and are lower than the as-measured values.

The $\mathrm{CO}_{2}, \mathrm{CO}, \mathrm{CH}_{4}, \mathrm{THC}$, and $\mathrm{NO}_{\mathrm{x}}$ levels tended to increase with increasing feedrate, consistent with the increase in the source terms of those species. The $\mathrm{NO}_{\mathrm{x}}$ level was also higher during Condition 3 when the target melt temperature $\left(1,300^{\circ} \mathrm{C}\right)$ and the feedrate were higher. The $\mathrm{H}_{2}$ levels were very close to detection limits based on the range of the analyzer, and so experienced more scatter than the other measurements. 


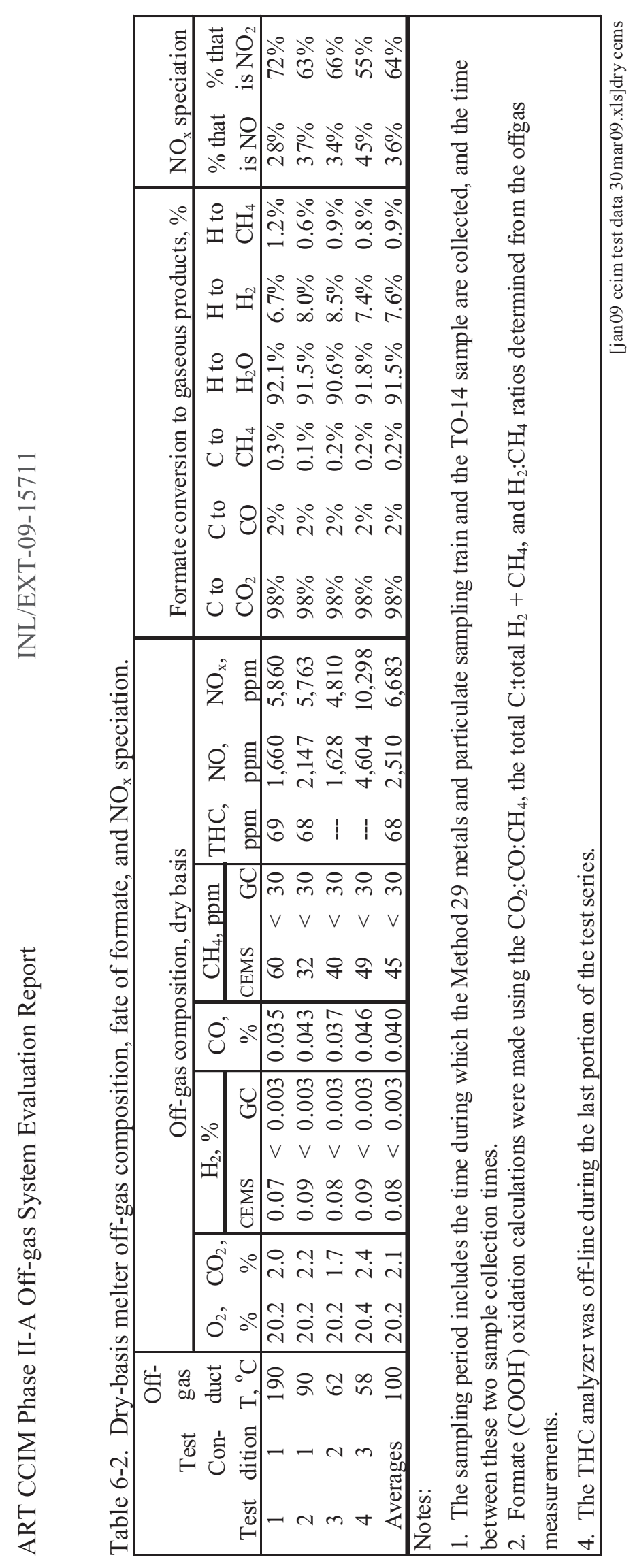




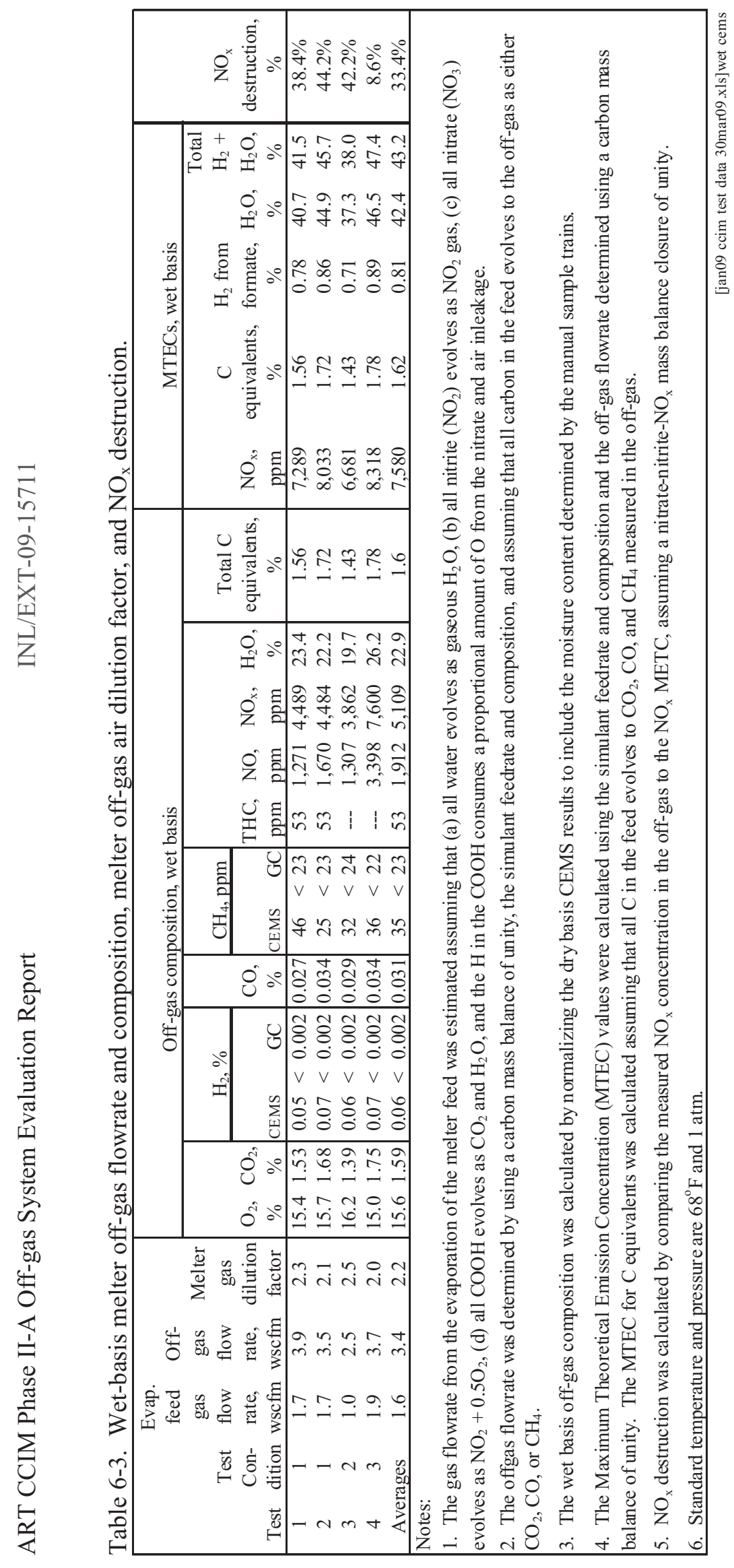




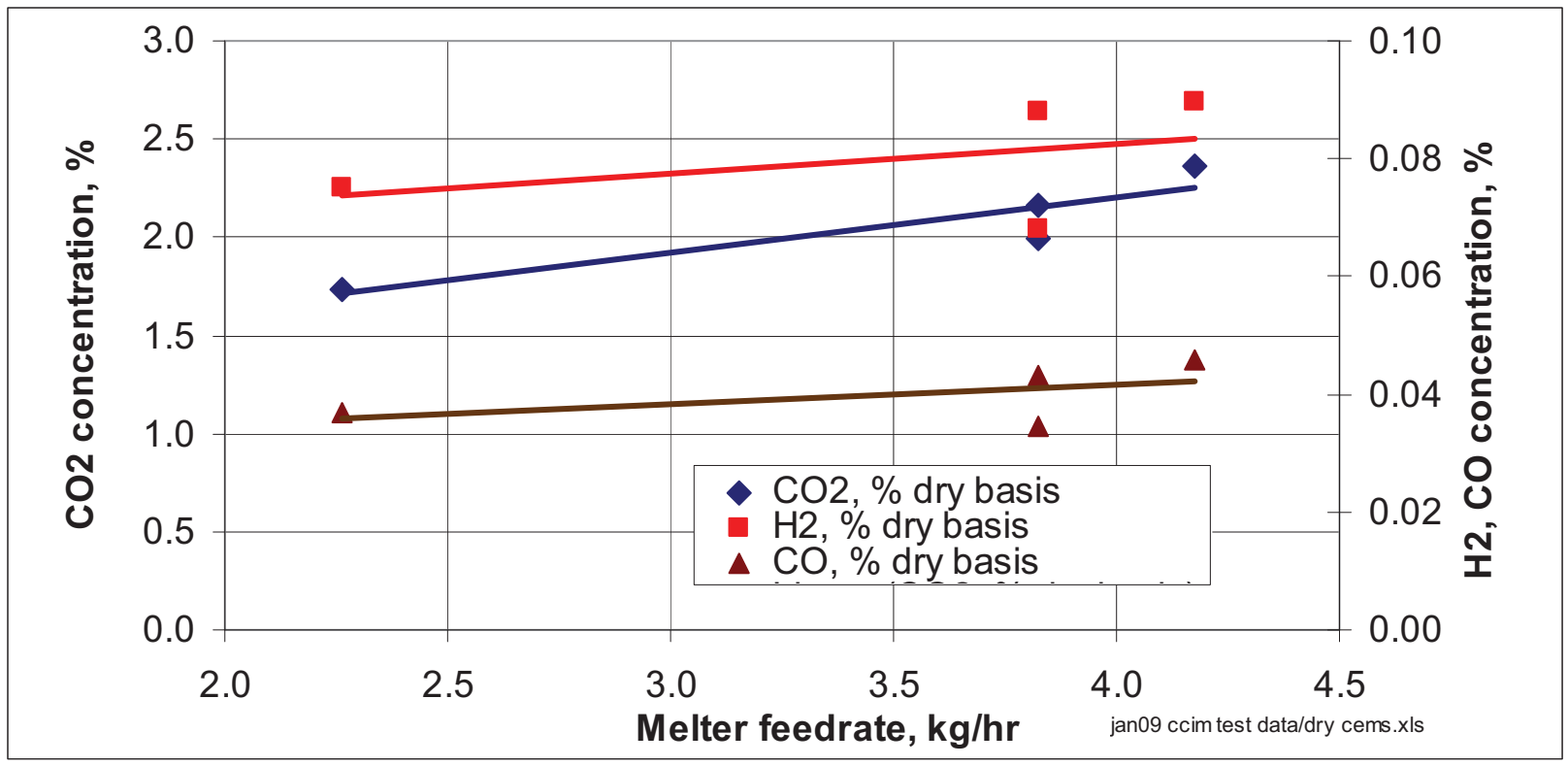

Figure 6-6. $\mathrm{CO}_{2}, \mathrm{H}_{2}$, and $\mathrm{CO}$ concentrations in the melter off-gas on a dry basis.

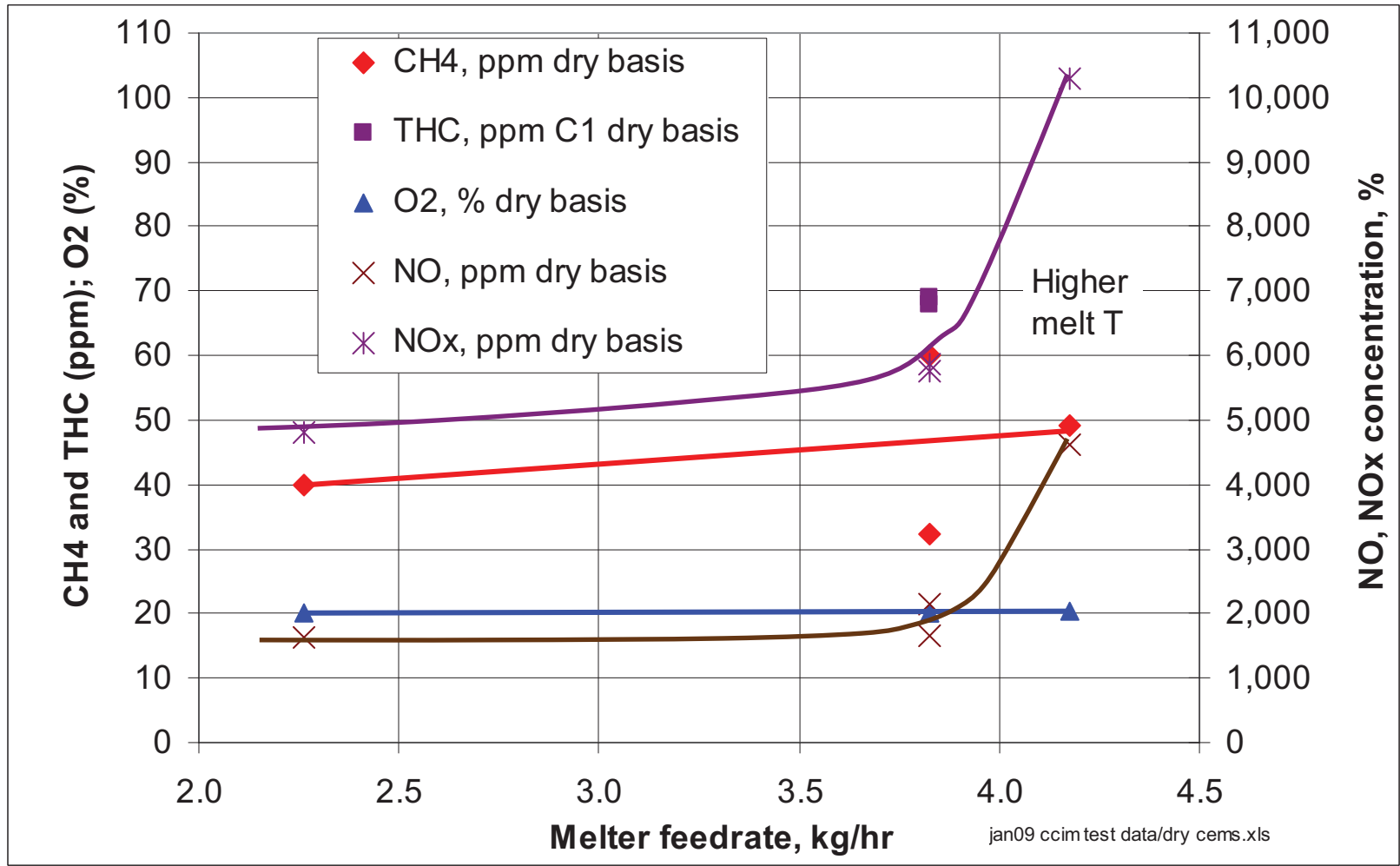

Figure 6-7. $\mathrm{CH}_{4}$, THC (reported as $\mathrm{CH}_{4}$ ), $\mathrm{O}_{2}, \mathrm{NO}$, and $\mathrm{NO}_{\mathrm{x}}$ concentrations in the melter off-gas (dry basis). 


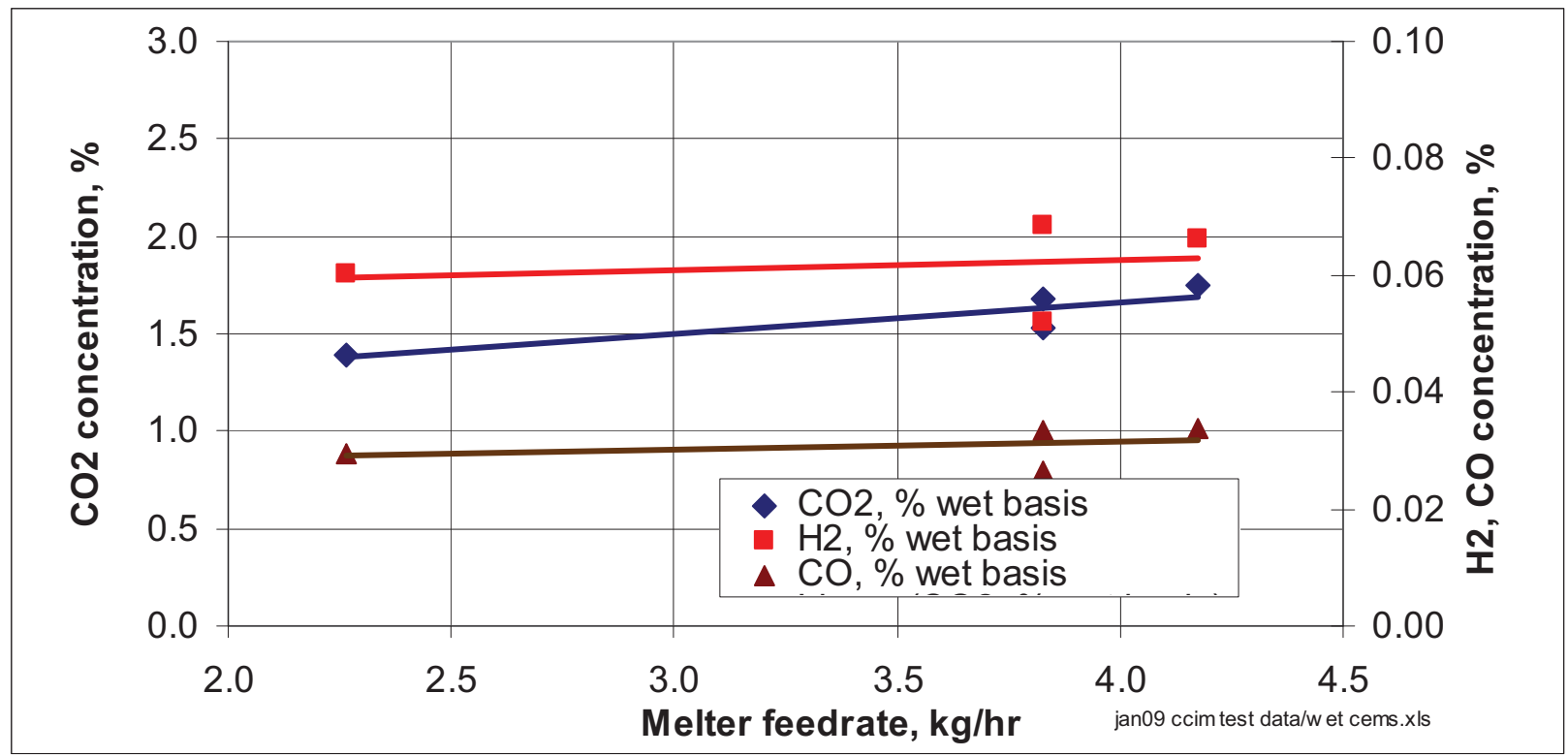

Figure 6-8. $\mathrm{CO}_{2}, \mathrm{H}_{2}$, and $\mathrm{CO}$ concentrations in the melter off-gas (wet basis).

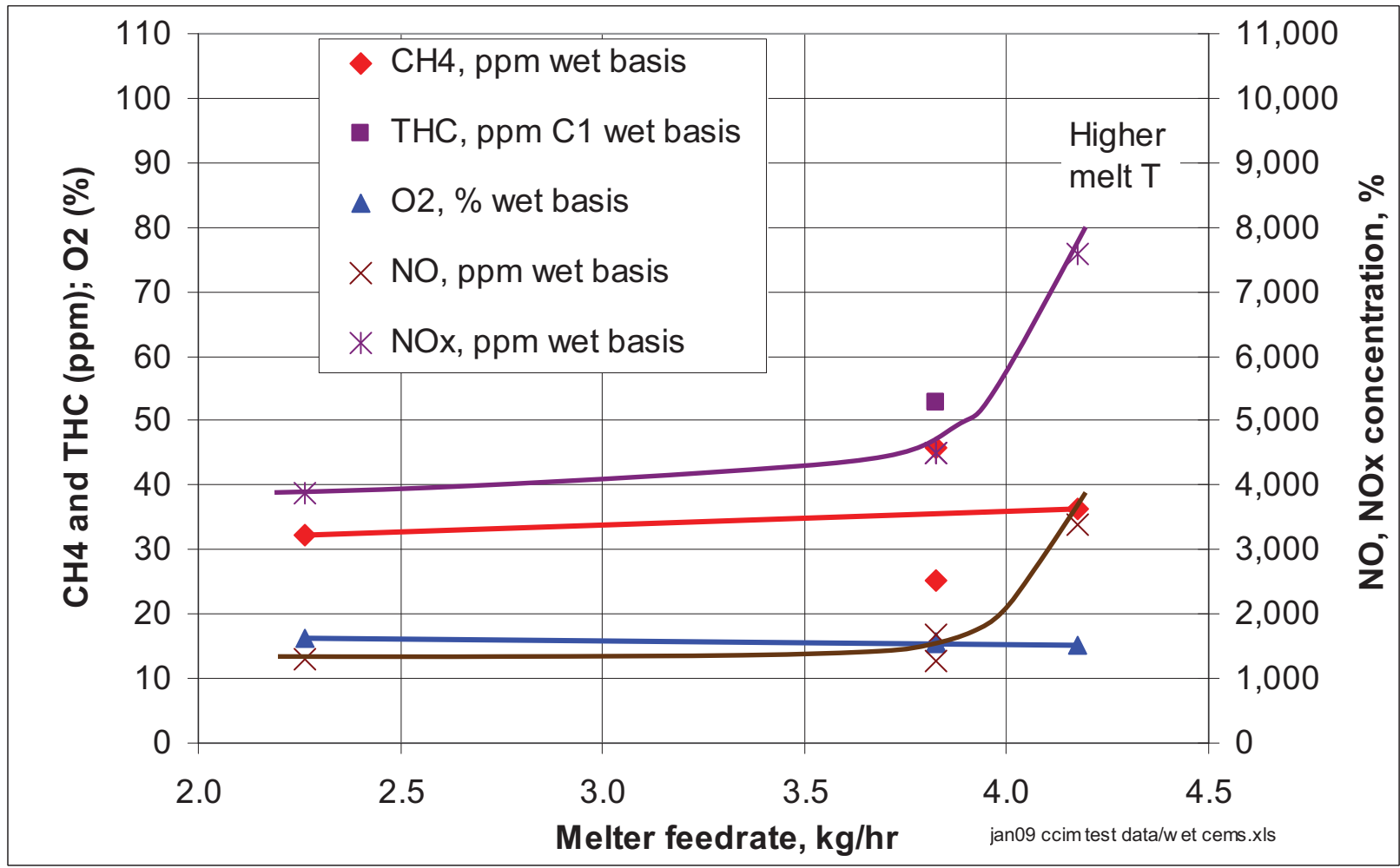

Figure 6-9. $\mathrm{CH}_{4}$, THC (reported as $\mathrm{CH}_{4}$ ), $\mathrm{O}_{2}, \mathrm{NO}$, and $\mathrm{NO}_{\mathrm{x}}$ concentrations in the melter off-gas (wet basis). 
Considering the importance of the $\mathrm{H}_{2}$ measurement, summa canister TO-14 grab samples were also collected and analyzed for $\mathrm{H}_{2}$ [and $\mathrm{CH}_{4}$ and VOCs, which are not speciated by the THC analysis]. The TO-14 $\mathrm{H}_{2}$ and $\mathrm{CH}_{4}$ measurements determined by $\mathrm{GC}$ analysis are included in the melter off-gas composition tables for comparison to the CEMS results. The $\mathrm{GC}$ results confirm that both $\mathrm{H}_{2}$ and $\mathrm{CH}_{4}$ concentrations are bounded by the higher CEMS results. Neither $\mathrm{H}_{2}$ nor $\mathrm{CH}_{4}$ were detected in the GC analyses, at lower detection limits than the levels indicated by the CEMS. Only the CEMS $\mathrm{H}_{2}$ and $\mathrm{CH}_{4}$ data, which are more complete for the entire demonstration and considered to be a conservatively high bounding level for the sample periods, are included in the melter off-gas composition figures, and used in calculations that determine the fate of the formate in the feed.

Dilution by air from the bubbler, view port purges, and air inleakage dilutes the off-gas evolved from evaporation, thermal decomposition, and REDOX reactions of the feed. Table 6-3 shows that the melter off-gas was diluted by about a factor of 2-2.5 for the different demonstration conditions. This dilution factor and the total melter off-gas flowrate were determined using a carbon balance, instead of using the off-gas flowrate measured using a pitot tube per EPA Method 1A and 2. This is because the melter off-gas velocity head, measured at about 0.015 inches water $(0.38 \mathrm{~mm}$ water $)$, was too low to be accurately determined using the pitot tube. The $\mathrm{CEMS} \mathrm{CO}_{2}$ measurement, which ranged between 1-2\%, was more valid as it was within the calibrated range of the $\mathrm{CO}_{2}$ analyzer and the $\mathrm{CO}_{2}$ analyzer responded well within calibration error limits for the duration of the demonstration.

Table 6-4 shows the results of the TO-14 VOC measurements. All of the data are flagged with either a "U" indicating that the species was not detected at the method detection limit (MDL), or with a "J" indicating that the species was detected at a concentration greater than the MDL, but less than the reporting limit (RL).

No VOCs were detected at levels above the RL, indicating that the reported values should be considered estimates. VOCs are typically detected at low-concentrations in GC/MS analysis of off-gas samples. None of the detected VOCs in the samples were detected in the laboratory blank sample. These low-level concentrations may be from low-level VOC contamination in the feed simulant, in the CCIM system, or in the sample canisters - or the formation of low concentrations of these species in the CCIM process.

The VOCs listed in the table below o-xylene were not included in the GC/MS calibration, and are tentatively identified from peaks found in the GC/MS analysis using a library of VOC species. Both the identification and the quantification of these species are not certain.

\subsubsection{Fate of Formate in the Simulant Feed}

Melter off-gas flammability is sometimes a concern when an organic reductant such as formic acid $(\mathrm{HCOOH})$ is used, as in this demonstration. Table 6-2 and Figure 6-10 show the fate of the formate in the feed, determined from the CEMS data. Ninety-eight percent of the carbon in the formate converted to $\mathrm{CO}_{2}$, and over $90 \%$ of the $\mathrm{H}$ converted to water vapor. Under $6-9 \%$ of the $\mathrm{H}$ in the formate converted to $\mathrm{H}_{2}$, and $2 \%$ of the formate decomposed to gaseous hydrocarbons or $\mathrm{CO}$. Wet basis $\mathrm{H}_{2}$ levels measured by the CEMS ranged between $0.05-0.07 \%, 30-40$ times lower than the $\mathrm{H}_{2}$ flammability limit in air. $\mathrm{H}_{2}$ was not detected at an even lower detection limit of $0.002 \%$ using the GC analysis of the summa canister samples. $\mathrm{H}_{2}$ levels at this detection limit are 1,000 times lower than the $\mathrm{H}_{2}$ flammability limit in air.

\subsubsection{Fate of Nitrate and Nitrite in the Feed}

The formate reductant is added to the feed to achieve the desired glass REDOX conditions. The formate, and decomposition products of the formate, also react with nitrite, nitrate, and $\mathrm{NO}_{\mathrm{x}}$ decomposition products. Table 6-3 and Figure 6-11 show that a portion (about 38-44\%) of the nitrate and nitrite in the feed was not converted to $\mathrm{NO}$ or $\mathrm{NO}_{2}$ in the off-gas when the target melt temperature was $1,250^{\circ} \mathrm{C}$. This portion of the nitrate/nitrite may have remained as either $\mathrm{HNO}_{3}$ or $\mathrm{HNO}_{2}$ in the melter offgas, or else it was converted to other nitrogen species such as $\mathrm{N}_{2}$. Only about $9 \%$ of the feed 
Table 6-4. VOC Concentrations in the melter off-gas (dry basis).

\begin{tabular}{|c|c|c|c|c|c|c|c|c|}
\hline \multirow{4}{*}{$\begin{array}{l}\text { Compound } \\
\text { Methanol (by GC) }\end{array}$} & \multicolumn{8}{|c|}{ Concentration, ppmv } \\
\hline & \multicolumn{4}{|c|}{ Test Condition 1} & \multirow{2}{*}{\multicolumn{2}{|c|}{$\begin{array}{c}\text { Test Condition } 2 \\
\text { Off-gas test } 3\end{array}$}} & \multirow{2}{*}{\multicolumn{2}{|c|}{$\begin{array}{c}\text { Test Condition } 3 \\
\text { Off-gas test } 4\end{array}$}} \\
\hline & \multicolumn{2}{|c|}{ Off-gas test 1} & \multicolumn{2}{|c|}{ Off-gas test 2} & & & & \\
\hline & $\mathrm{U}$ & 8.5 & $\mathrm{U}$ & 8.4 & $\mathrm{U}$ & 7.9 & & \\
\hline Acetone & $\mathrm{J}$ & 1.7 & $\mathrm{~J}$ & 1.3 & $\mathrm{~J}$ & 0.77 & $\mathrm{~J}$ & 1.9 \\
\hline Benzene & $\mathrm{J}$ & 0.18 & $\mathrm{~J}$ & 0.18 & $\mathrm{~J}$ & 0.099 & $\mathrm{~J}$ & 0.25 \\
\hline Bromoform & $\mathrm{U}$ & 0.0021 & $\mathrm{U}$ & 0.002 & $\mathrm{U}$ & 0.0019 & $\mathrm{U}$ & 0.002 \\
\hline Butanol & $\mathrm{J}$ & 0.021 & $\mathrm{~J}$ & 0.026 & $\mathrm{U}$ & 0.0082 & $\mathrm{~J}$ & 0.014 \\
\hline Carbon disulfide & $\mathrm{U}$ & 0.0074 & $\mathrm{U}$ & 0.0073 & $\mathrm{U}$ & 0.0069 & $\mathrm{U}$ & 0.0071 \\
\hline Carbon tetrachloride & $\mathrm{U}$ & 0.0039 & $\mathrm{U}$ & 0.0038 & $\mathrm{U}$ & 0.0036 & $\mathrm{U}$ & 0.0038 \\
\hline Chlorobenzene & $\mathrm{U}$ & 0.0063 & $\mathrm{U}$ & 0.0062 & $\mathrm{U}$ & 0.0058 & $\mathrm{U}$ & 0.006 \\
\hline Chloroform & $\mathrm{U}$ & 0.0058 & $\mathrm{U}$ & 0.0057 & $\mathrm{U}$ & 0.0054 & $\mathrm{U}$ & 0.0056 \\
\hline Chloromethane & $\mathrm{J}$ & 0.062 & $\mathrm{~J}$ & 0.12 & $\mathrm{~J}$ & 0.072 & $\mathrm{~J}$ & 0.15 \\
\hline Cyclohexane & $\mathrm{U}$ & 0.0068 & $\mathrm{U}$ & 0.0067 & $\mathrm{U}$ & 0.0064 & $\mathrm{U}$ & 0.0066 \\
\hline 1,1-Dichloroethane & $\mathrm{U}$ & 0.0071 & $\mathrm{U}$ & 0.007 & $\mathrm{U}$ & 0.0066 & $\mathrm{U}$ & 0.0069 \\
\hline 1,2-Dichloroethane & $\mathrm{U}$ & 0.0083 & $\mathrm{U}$ & 0.0082 & $\mathrm{U}$ & 0.0077 & $\mathrm{U}$ & 0.008 \\
\hline 1,1 -Dichloroethylene & $\mathrm{U}$ & 0.0065 & $\mathrm{U}$ & 0.0064 & $\mathrm{U}$ & 0.006 & $\mathrm{U}$ & 0.0062 \\
\hline cis-i ,2-Dichloroethylene & $\mathrm{U}$ & 0.0052 & $\mathrm{U}$ & 0.0052 & $\mathrm{U}$ & 0.0049 & $\mathrm{U}$ & 0.005 \\
\hline trans-i ,2-Dichloroethylene & $\mathrm{U}$ & 0.0069 & $\mathrm{U}$ & 0.0068 & $\mathrm{U}$ & 0.0064 & $\mathrm{U}$ & 0.0066 \\
\hline 1 ,2-Dichloropropane & $\mathrm{U}$ & 0.0058 & $\mathrm{U}$ & 0.0057 & $\mathrm{U}$ & 0.0054 & $\mathrm{U}$ & 0.0056 \\
\hline Ethyl benzene & $\mathrm{U}$ & 0.0059 & $\mathrm{U}$ & 0.0058 & $\mathrm{U}$ & 0.0055 & $\mathrm{U}$ & 0.0057 \\
\hline Ethyl ether & $\mathrm{U}$ & 0.0095 & $\mathrm{U}$ & 0.0094 & $\mathrm{U}$ & 0.0089 & $\mathrm{U}$ & 0.0092 \\
\hline Methyl ethyl ketone & $\mathrm{J}$ & 0.12 & $\mathrm{~J}$ & 0.08 & $\mathrm{~J}$ & 0.045 & $\mathrm{~J}$ & 0.073 \\
\hline Methyl isobutyl ketone & $\mathrm{U}$ & 0.0077 & $\mathrm{U}$ & 0.0076 & $\mathrm{U}$ & 0.0072 & $\mathrm{U}$ & 0.0074 \\
\hline Methylene chloride & $\mathrm{U}$ & 0.0092 & $\mathrm{U}$ & 0.0091 & $\mathrm{U}$ & 0.0086 & $\mathrm{U}$ & 0.0089 \\
\hline $1,1,2,2$-Tetrachloroethane & $\mathrm{U}$ & 0.0056 & $\mathrm{U}$ & 0.0055 & $\mathrm{U}$ & 0.0052 & $\mathrm{U}$ & 0.0054 \\
\hline Tetrachloroethylene & $\mathrm{U}$ & 0.0051 & $\mathrm{U}$ & 0.005 & $\mathrm{U}$ & 0.0048 & $\mathrm{U}$ & 0.0049 \\
\hline Toluene & $\mathrm{J}$ & 0.0099 & $\mathrm{~J}$ & 0.01 & $\mathrm{U}$ & 0.0069 & $\mathrm{~J}$ & 0.0099 \\
\hline 1,1,1-Trichloroethane & $\mathrm{U}$ & 0.0047 & $\mathrm{U}$ & 0.0046 & $\mathrm{U}$ & 0.0044 & $\mathrm{U}$ & 0.0045 \\
\hline Trichloroethylene & $\mathrm{U}$ & 0.0046 & $\mathrm{U}$ & 0.0045 & $\mathrm{U}$ & 0.0043 & $\mathrm{U}$ & 0.0044 \\
\hline Trichlorofluoromethane & $\mathrm{U}$ & 0.0073 & $\mathrm{U}$ & 0.0072 & $\mathrm{U}$ & 0.0068 & $\mathrm{U}$ & 0.007 \\
\hline i ,i ,2-Trichloro-1 ,2,2-trifluoroethane & $\mathrm{U}$ & 0.0054 & $\mathrm{U}$ & 0.0054 & $\mathrm{U}$ & 0.0051 & $\mathrm{U}$ & 0.0052 \\
\hline $1,3,5$-Trimethylbenzene & $\mathrm{U}$ & 0.0074 & $\mathrm{U}$ & 0.0073 & $\mathrm{U}$ & 0.0069 & $\mathrm{U}$ & 0.0071 \\
\hline $1,2,4$-Trimethylbenzene & $\mathrm{U}$ & 0.0072 & $\mathrm{U}$ & 0.0071 & $\mathrm{U}$ & 0.0067 & $\mathrm{U}$ & 0.0069 \\
\hline $\mathrm{p} / \mathrm{m}$-Xylene & $\mathrm{U}$ & 0.0066 & $\mathrm{U}$ & 0.0066 & $\mathrm{U}$ & 0.0062 & $\mathrm{U}$ & 0.0064 \\
\hline o-Xylene & $\mathrm{U}$ & 0.0076 & $\mathrm{U}$ & 0.0075 & $\mathrm{U}$ & 0.0071 & $\mathrm{U}$ & 0.0073 \\
\hline Possible Propene & $\mathrm{J}$ & 1.8 & $\mathrm{~J}$ & 1.6 & $\mathrm{~J}$ & 0.85 & $\mathrm{~J}$ & 1.9 \\
\hline Fluorotrimethylsilane & $\mathrm{J}$ & 6 & $\mathrm{~J}$ & 3.1 & $\mathrm{~J}$ & 1.7 & $\mathrm{~J}$ & 4.7 \\
\hline Acetonitrile & $\mathrm{J}$ & 1.9 & $\mathrm{~J}$ & 1.5 & $\mathrm{~J}$ & 0.8 & $\mathrm{~J}$ & 2.1 \\
\hline Possible 2-Propenenitrile & $\mathrm{J}$ & 0.4 & $\mathrm{~J}$ & 0.36 & $\mathrm{~J}$ & 0.18 & $\mathrm{~J}$ & 0.5 \\
\hline Unknown & $\mathrm{J}$ & 0.046 & $\mathrm{~J}$ & 0.092 & $\mathrm{~J}$ & 0.033 & $\mathrm{~J}$ & 0.091 \\
\hline Hexamethylcyclotrisiloxane & $\mathrm{J}$ & 0.084 & & --- & & --- & $\mathrm{J}$ & 0.021 \\
\hline Unknown & & --- & & --- & & --- & & --- \\
\hline Possible Butenenitrile or isomer & & --- & $\mathrm{J}$ & 0.071 & $\mathrm{~J}$ & 0.025 & & --- \\
\hline 2-Methyl-2-propenenitrile & & --- & & --- & $\mathrm{J}$ & 0.047 & & --- \\
\hline Possible 2-bromo-1-chloropropane & & --- & & --- & $\mathrm{J}$ & 0.02 & $\mathrm{~J}$ & 0.053 \\
\hline Possible 2-bromo-1-chloropropane & & --- & & --- & $\mathrm{J}$ & 0.036 & $\mathrm{~J}$ & 0.097 \\
\hline Unknown & & --- & & --- & $\mathrm{J}$ & 0.031 & & --- \\
\hline 2-Butenenitrile & & --- & & -- & & --- & $\mathrm{J}$ & 0.069 \\
\hline $\begin{array}{l}\text { Notes: } \\
\text { 1. Flag U indicates the analyte was no } \\
\text { 2. Flag J indicates the analyte was det } \\
\text { 3. The sample from Off-gas test } 1 \text { was } \\
\text { 4. Methanol was measured using GC; }\end{array}$ & in & $\begin{array}{l}\text { luplicate } \\
\text { Cs in this }\end{array}$ & & IDL, but & man & $\begin{array}{l}\text { seportin } \\
\text { st analys } \\
\text { MS. }\end{array}$ & (RL & $\begin{array}{l}\text { MDL). } \\
\text { ere. }\end{array}$ \\
\hline
\end{tabular}




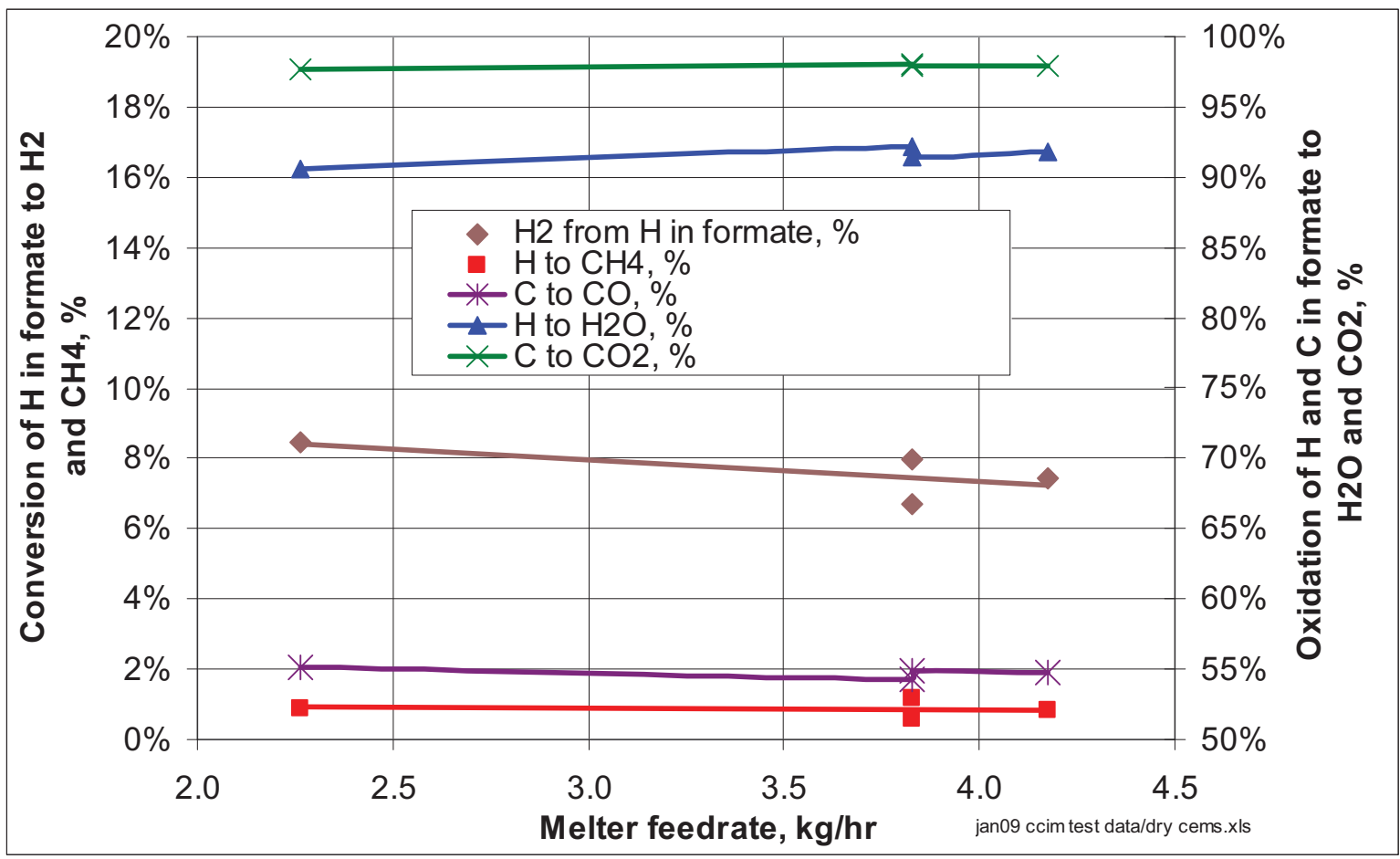

Figure 6-10. Fate of formate in the feed during CCIM processing.

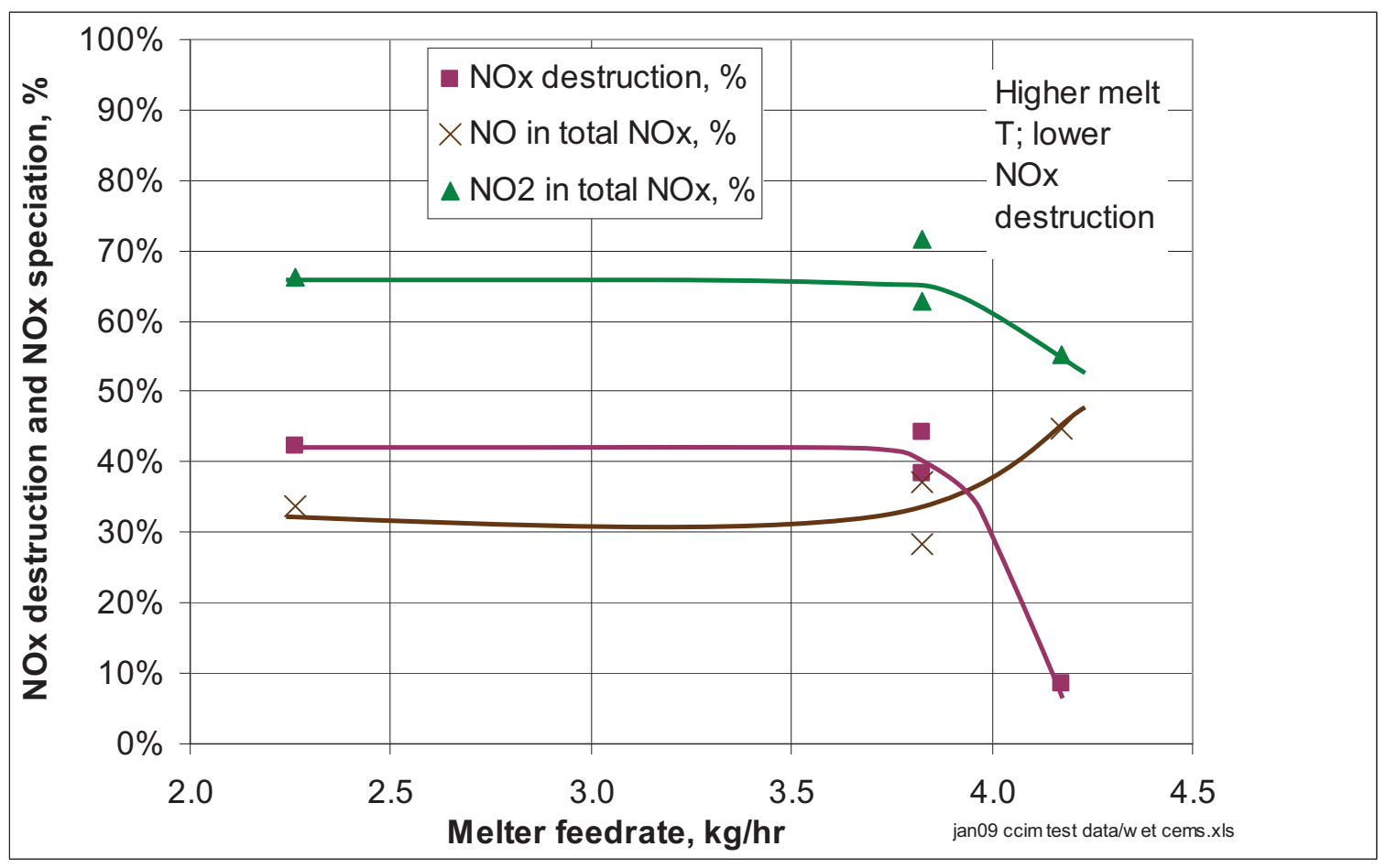

Figure 6-11. $\mathrm{NO}_{\mathrm{x}}$ destruction and $\mathrm{NO}_{\mathrm{x}}$ speciation during CCIM processing. 
nitrate/nitrite was unaccounted for when the melt temperature was $300^{\circ} \mathrm{C}$. Assuming that this "missing $\mathrm{NO}_{\mathrm{x}}$ " is due to conversion of a portion of the feed nitrite and nitrate to $\mathrm{N}_{2}$, the difference is reported as $\mathrm{NO}_{\mathrm{x}}$ destruction.

The speciation between $\mathrm{NO}$ and $\mathrm{NO}_{2}$ is shown in Table 6-2 and Figure 6-11. Roughly $2 / 3$ of the total measured $\mathrm{NO}_{\mathrm{x}}$ was $\mathrm{NO}_{2}$, and roughly $1 / 3$ was $\mathrm{NO}$. Other species such as $\mathrm{HNO}_{2}, \mathrm{HNO}_{3}$, and $\mathrm{N}_{2} \mathrm{O}$ were not specifically measured. The chemiluminescent $\mathrm{NO}_{\mathrm{x}}$ analyzer uses a vitreous carbon $\mathrm{NO}_{\mathrm{x}}$ converter to convert $\mathrm{NO}_{2}$ to $\mathrm{NO}$, so the $\mathrm{NO}_{2}$ can be measured in addition to $\mathrm{NO}$. The $\mathrm{NO}$ is detected when the sample gas bypasses the $\mathrm{NO}_{\mathrm{x}}$ converter. Total $\mathrm{NO}$ and $\mathrm{NO}_{2}$ are detected when the sample gas passes through the $\mathrm{NO}_{\mathrm{x}}$ converter. The calculated difference is normally assumed to be $\mathrm{NO}_{2}$. This $\mathrm{NO}_{\mathrm{x}}$ converter also converts some of $\mathrm{HNO}_{2}$ and $\mathrm{HNO}_{3}$, if present in the sample gas, to NO. The measurements reported as total $\mathrm{NO}_{\mathrm{x}}$ and $\mathrm{NO}_{2}$ will then also include some $\mathrm{HNO}_{2}$ and $\mathrm{HNO}_{3}$, if these species are present in the off-gas and are not scrubbed out of the sample gas in the condenser upstream of the $\mathrm{NO}_{\mathrm{x}}$ analyzer.

\subsubsection{Melter Off-gas Particulate and Metals Emissions}

Table 6-5 shows the concentration and emission rate measurements for total PM and each metal that was analyzed in the melter off-gas samples. These results include both gas-phase and aerosol-phase metals in the off-gas. The total PM concentration ranged from $12-29 \mathrm{mg} / \mathrm{wscf}$ ( $\mathrm{mg}$ per wet standard cubic foot) $[340-821 \mathrm{mg} / \mathrm{wncm}$ (mg per wet normal cubic meter)]. The total PM emission rate ranged from $2.8-4.5 \mathrm{gm} / \mathrm{hr}$. This PM emission rate corresponds to $0.16-0.41 \%$ of the calcined solids input rate.

The metals analyzed in the feed and the glass were also analyzed in the off-gas, except for $\mathrm{Si}$. Si cannot be analyzed for in the off-gas samples because a glass-fiber filter that is $100 \% \mathrm{SiO}_{2}$ is used in the Method 5/29 sample train to capture solid-phase PM. This filter is designed and operated to capture $99.97 \%$ of particulate matter of 0.3 micron diameter. Any metal vapor, volatilized metals, or fine particulate that pass through this filter are scrubbed in acidified nitric acid - hydrogen peroxide impingers downstream of the filter. In this way, the Method 5/29 sample train is used measure off-gas PM and metals emissions, regardless of whether metals are in solid or gaseous phase.

The metals concentrations and mass emission rates vary over three orders of magnitude, depending on the concentration of those metals in the feed and volatility of species formed from those metals at elevated temperatures. Figure 6-12 compares the total PM emission rate to the emission rates of Cs (known to be more volatile at high temperatures) and Fe (known to be less volatile at elevated temperatures) for the three different demonstration conditions. The highest total PM concentration occurred for Condition 2, which had the lowest feedrate and the least cold cap coverage. The Fe and Cs emission rates were slightly higher for the lower cold-cap condition (Condition 2) and for the higher feedrate, higher melt temperature Condition 3, compared to the average emission rates for the two baseline tests (Condition 1).

The Cs emission rate was about 10 times higher than the Fe emission rate, even though the Cs concentration in the feed and the glass products was about 30 times lower than was the Fe concentration. This illustrates that even though off-gas emissions of the more volatile metals can be higher than for nonvolatile metals, non-volatile metals are still entrained into the off-gas.

The following section provides more results of mass balance and partitioning determinations for total solids and metals, between the off-gas PM and the product glass. 
Table 6-5. Melter off-gas particulate and metals concentrations and emission rates.

\begin{tabular}{|c|c|c|c|c|c|c|}
\hline \multirow{2}{*}{\multicolumn{2}{|c|}{ Units }} & \multicolumn{4}{|c|}{ Off-gas test } & \multirow{2}{*}{$\begin{array}{l}\text { Weighted } \\
\text { averages }\end{array}$} \\
\hline & & 1 & 2 & 3 & 4 & \\
\hline \multicolumn{2}{|l|}{ Test condition } & 1 & 1 & 2 & 3 & --- \\
\hline Test condition duration & $\mathrm{hr}$ & \multicolumn{2}{|c|}{24.83} & 22.21 & 7.70 & \\
\hline Total PM concentration & $\mathrm{mg} / \mathrm{wscf}$ & 12 & 21 & 29 & 20 & 22 \\
\hline Total PM concentration & $\mathrm{mg} / \mathrm{wncm}$ & 340 & 594 & 821 & 566 & 624 \\
\hline Total PM emission rate & $\mathrm{gm} / \mathrm{hr}$ & 2.8 & 4.5 & 4.4 & 4.5 & 4.1 \\
\hline Calcined solids input rate & $\mathrm{kg} / \mathrm{hr}$ & 1.45 & 1.45 & 0.86 & 1.58 & 1.22 \\
\hline Total solids split to off-gas & $\%$ & 0.19 & 0.31 & 0.51 & 0.28 & 0.36 \\
\hline \multicolumn{7}{|c|}{ Metals concentrations $\quad$ ug/wscf } \\
\hline $\mathrm{Al}$ & & 224.5 & 79.8 & 145.5 & 199.8 & 156.2 \\
\hline B & & 574.1 & 566.3 & 634.5 & 615.7 & 602.7 \\
\hline $\mathrm{Ba}$ & & 48.4 & 14.0 & 12.0 & 14.4 & 21.1 \\
\hline $\mathrm{Ca}$ & & 202.0 & 35.0 & 53.0 & 109.1 & 90.6 \\
\hline $\mathrm{Cr}$ & & 3.9 & 14.6 & 20.3 & 14.1 & 14.4 \\
\hline Cs & & $1,339.2$ & $2,829.9$ & $3,108.2$ & $2,449.0$ & $2,551.1$ \\
\hline $\mathrm{Cu}$ & & 8.4 & 23.3 & 22.0 & 19.1 & 18.8 \\
\hline $\mathrm{Fe}$ & & 188.2 & 155.2 & 295.4 & 300.4 & 240.0 \\
\hline K & & 630.3 & 726.7 & 827.4 & 660.3 & 736.3 \\
\hline $\mathrm{Li}$ & & 118.1 & 204.7 & 295.2 & 209.3 & 222.4 \\
\hline $\mathrm{Mg}$ & & 23.1 & 15.1 & 23.3 & 25.6 & 21.7 \\
\hline $\mathrm{Mn}$ & & 44.1 & 40.0 & 72.6 & 71.2 & 58.5 \\
\hline $\mathrm{Na}$ & & $2,218.8$ & $2,093.8$ & $2,818.6$ & $2,780.6$ & $2,512.8$ \\
\hline $\mathrm{Ni}$ & & 18.3 & 16.4 & 29.0 & 25.9 & 23.3 \\
\hline $\mathrm{P}$ & & 11.2 & 11.3 & 11.8 & 12.1 & 11.6 \\
\hline S & & 290.5 & 317.6 & 604.7 & 345.8 & 431.9 \\
\hline $\mathrm{Si}$ & & --- & --- & --- & --- & -- \\
\hline $\mathrm{Ti}$ & & 5.3 & 2.6 & 1.5 & 1.3 & 2.6 \\
\hline $\mathrm{Zn}$ & & 487.1 & 506.1 & 525.7 & 539.6 & 514.5 \\
\hline $\mathrm{Zr}$ & & 6.6 & 6.2 & 6.4 & 6.6 & 6.4 \\
\hline Totals & & $6,442.1$ & $7,658.6$ & $9,507.1$ & $8,399.9$ & $8,237.0$ \\
\hline Sum metals, $\%$ of total PM & $\%$ & $54 \%$ & $36 \%$ & $33 \%$ & $42 \%$ & $37 \%$ \\
\hline \multicolumn{7}{|c|}{$\begin{array}{ll}\text { Metals emission rates } & \mathrm{mg} / \mathrm{hr}\end{array}$} \\
\hline $\mathrm{Al}$ & & 52.7 & 17.0 & 22.0 & 44.8 & 31.1 \\
\hline B & & 134.7 & 120.6 & 96.1 & 138.1 & 116.3 \\
\hline $\mathrm{Ba}$ & & 11.4 & 3.0 & 1.8 & 3.2 & 4.4 \\
\hline $\mathrm{Ca}$ & & 47.4 & 7.4 & 8.0 & 24.5 & 19.1 \\
\hline $\mathrm{Cr}$ & & 0.9 & 3.1 & 3.1 & 3.2 & 2.6 \\
\hline Cs & & 314.3 & 602.6 & 470.8 & 549.4 & 476.2 \\
\hline $\mathrm{Cu}$ & & 2.0 & 5.0 & 3.3 & 4.3 & 3.5 \\
\hline $\mathrm{Fe}$ & & 44.2 & 33.1 & 44.7 & 67.4 & 45.1 \\
\hline K & & 147.9 & 154.7 & 125.3 & 148.1 & 140.3 \\
\hline $\mathrm{Li}$ & & 27.7 & 43.6 & 44.7 & 47.0 & 40.9 \\
\hline $\mathrm{Mg}$ & & 5.4 & 3.2 & 3.5 & 5.7 & 4.2 \\
\hline $\mathrm{Mn}$ & & 10.3 & 8.5 & 11.0 & 16.0 & 11.0 \\
\hline $\mathrm{Na}$ & & 520.7 & 445.8 & 426.9 & 623.8 & 480.2 \\
\hline $\mathrm{Ni}$ & & 4.3 & 3.5 & 4.4 & 5.8 & 4.4 \\
\hline $\mathrm{P}$ & & 2.6 & 2.4 & 1.8 & 2.7 & 2.2 \\
\hline S & & 68.2 & 67.6 & 91.6 & 77.6 & 78.9 \\
\hline $\mathrm{Si}$ & & --- & --- & -- & -- & -- \\
\hline $\mathrm{Ti}$ & & 1.2 & 0.6 & 0.2 & 0.3 & 0.5 \\
\hline $\mathrm{Zn}$ & & 114.3 & 107.8 & 79.6 & 121.1 & 99.7 \\
\hline $\mathrm{Zr}$ & & 1.6 & 1.3 & 1.0 & 1.5 & 1.3 \\
\hline Totals & & $1,511.7$ & $1,630.7$ & $1,440.0$ & $1,884.4$ & $1,562.0$ \\
\hline \multicolumn{7}{|c|}{$\begin{array}{l}\text { Notes: } \\
\text { 1. Italic values are detection limit values for elements that were not detected. } \\
\text { 2. The initial mass of the starting glass, and the mass of deposits recovered from the } \\
\text { melter freeboard and off-gas pipe, are not included in these calculations, because these } \\
\text { calculations only apply to the off-gas sampling periods. }\end{array}$} \\
\hline
\end{tabular}

[jan09 ccim test data 30mar09.xls] offgas metals, pm 


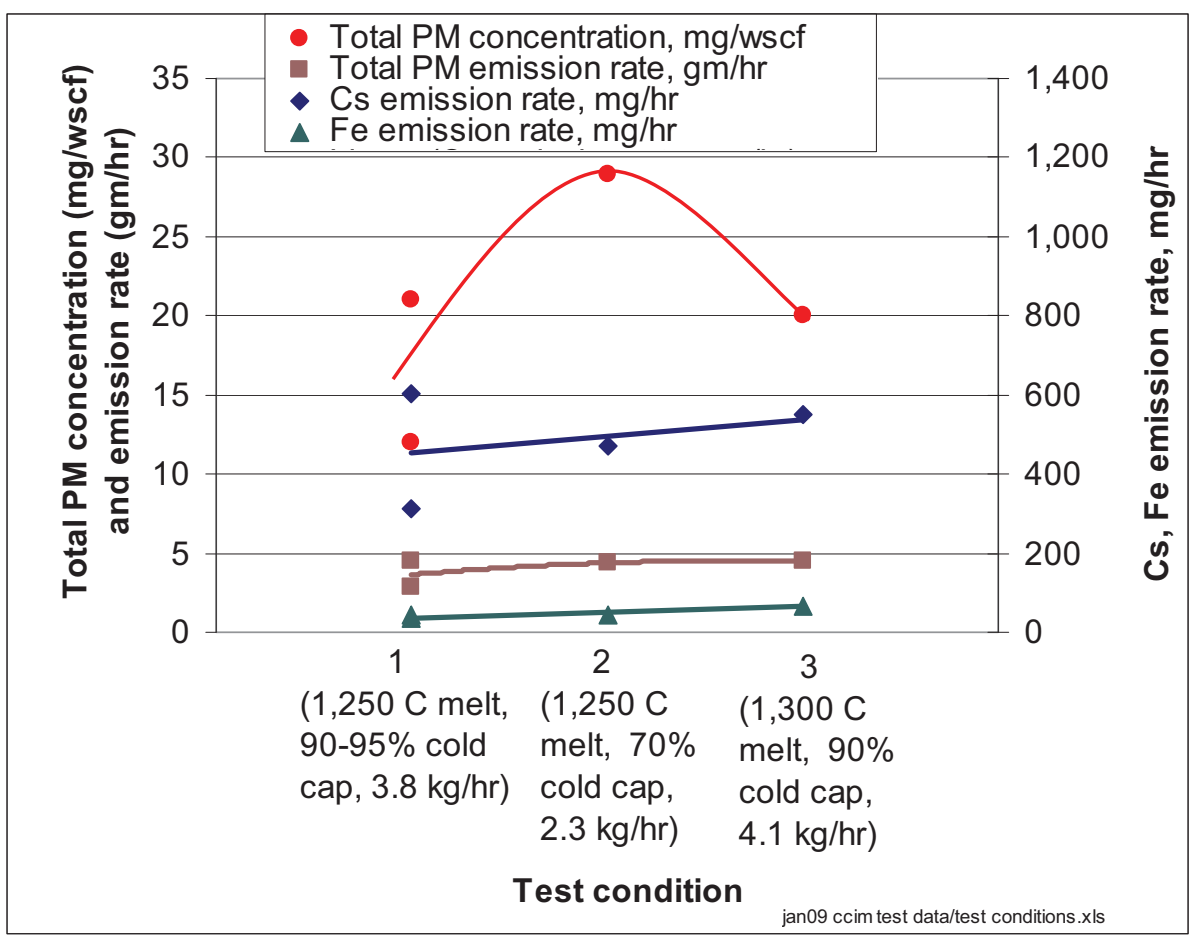

Figure 6-12. Total particulate matter, $\mathrm{Cs}$, and Fe emission rates for the different demonstration conditions.

\subsection{Mass Balance and Partitioning Results}

Mass balances were performed using composition analyses, process rates, and masses of the input and output streams. The mass balances were determined using the compositions and masses of the simulant feed, the glass product drained from the melter during operation and removed from the crucible after shutdown, all deposits in the melter freeboard and off-gas duct upstream of the off-gas PM and metals sample location, and the results of the off-gas PM and metals measurements.

While more volatile metals are more prone to volatilize from the melter at the elevated melter temperatures, all metals in the feed will evolve from the melter in dust entrained from the cold cap and in fume volatilized and physically ejected (through bubbling and entrainment in gas that passes through the cold cap and the melt surface). Physical and thermodynamic mechanisms that result in evolution of feed material into the off-gas that would otherwise be incorporated into the glass product include (a) volatilization at elevated melt temperatures, with or without subsequent condensation into "fume" particles, (b) physical entrainment in the melter off-gas of dust particles formed in the cold cap as the feed dries, and (c) physical ejection of molten glass aerosols through bubbling of gas in the melt or other turbulence.

Table 6-6 shows the concentrations of the input and output streams used in the mass balance calculations, the glass product specific gravity, and glass REDOX values. The concentrations of the different glass drain samples varied little over time, and varied little from the glass samples removed from the melter after the demonstration end, and were also similar to the composition of the starting glass. The weighted average glass product composition was calculated for determining the average composition of the total glass product mass. The weighted average composition of the off-gas solids was also calculated using the sample train data and the duration for each of the demonstration conditions represented by each off-gas sample period. 
Table 6-6. Input and output stream compositions (used in mass balance calculations) and glass properties.

\begin{tabular}{|c|c|c|c|c|c|c|c|c|c|c|c|c|}
\hline & \multicolumn{2}{|c|}{ Input streams } & \multicolumn{9}{|c|}{ Output streams } & \multirow{4}{*}{\begin{tabular}{|c} 
Aver- \\
age \\
metal \\
enrich- \\
ment \\
in the \\
off-gas \\
PM
\end{tabular}} \\
\hline & \multirow{2}{*}{$\begin{array}{l}\text { Start- } \\
\text { ing } \\
\text { glass }\end{array}$} & \multirow{2}{*}{$\begin{array}{c}\text { Simulant } \\
\text { feed }\end{array}$} & \multicolumn{4}{|c|}{ Glass drains } & \multirow{2}{*}{$\begin{array}{l}\text { Final } \\
\text { clean- } \\
\text { out } \\
\text { glass }\end{array}$} & \multirow{2}{*}{$\begin{array}{l}\text { Free- } \\
\text { board } \\
\text { glass }\end{array}$} & \multirow{2}{*}{$\begin{array}{c}\text { Weighted } \\
\text { average } \\
\text { product } \\
\text { glass } \\
\end{array}$} & \multirow{2}{*}{\begin{tabular}{|c|} 
Lid \& \\
off-gas \\
pipe \\
solids \\
\end{tabular}} & \multirow{2}{*}{$\begin{array}{c}\text { Off-gas } \\
\text { PM } \\
\text { Weighted } \\
\text { average } \\
\end{array}$} & \\
\hline & & & 1 & 2 & 3 & 4 & & & & & & \\
\hline Sample number & 017 & $\begin{array}{l}\text { Avg } \\
006 \\
009 \\
\end{array}$ & 010 & 011 & 012 & 013 & 014 & 015 & --- & 016 & --- & \\
\hline Cations, wt \% & & & & & & & & & & & & \\
\hline $\mathrm{Al}$ & 5.45 & 2.62 & 6.26 & 6.53 & 6.38 & 6.88 & 6.63 & 6.92 & 6.61 & --- & 0.71 & 0.1 \\
\hline B & 2.26 & 0.82 & 2.23 & 2.19 & 2.25 & 2.30 & 2.16 & 2.14 & 2.21 & --- & 2.73 & 1.2 \\
\hline $\mathrm{Ba}$ & 0.03 & 0.01 & 0.03 & 0.03 & 0.03 & 0.03 & 0.03 & 0.03 & 0.03 & --- & 0.10 & 3.1 \\
\hline $\mathrm{Ca}$ & 1.17 & 0.45 & 1.15 & 1.17 & 1.14 & 1.23 & 1.19 & 1.08 & 1.18 & --- & 0.41 & 0.3 \\
\hline $\mathrm{Cr}$ & 0.05 & 0.025 & 0.04 & 0.05 & 0.05 & 0.06 & 0.05 & 0.06 & 0.05 & --- & 0.07 & 1.3 \\
\hline Cs & 0.237 & 0.11 & 0.26 & 0.27 & 0.28 & 0.28 & 0.28 & 0.32 & 0.28 & 0.47 & 11.56 & 41.6 \\
\hline $\mathrm{Cu}$ & 0.02 & 0.01 & 0.03 & 0.03 & 0.03 & 0.03 & 0.03 & 0.03 & 0.03 & --- & 0.09 & 3.1 \\
\hline $\mathrm{Fe}$ & 9.49 & 3.93 & 9.20 & 9.45 & 9.06 & 9.14 & 9.71 & 10.30 & 9.47 & --- & 1.09 & 0.1 \\
\hline $\mathrm{K}$ & 1.13 & 0.07 & 0.53 & 0.38 & 0.38 & 0.26 & 0.49 & 0.26 & 0.42 & --- & 3.34 & 8.0 \\
\hline $\mathrm{Li}$ & 1.99 & 0.81 & 2.16 & 2.15 & 2.21 & 2.12 & 2.08 & 2.08 & 2.12 & --- & 1.01 & 0.5 \\
\hline $\mathrm{Mg}$ & 0.71 & 0.38 & 0.74 & 0.96 & 0.91 & 1.07 & 0.88 & 0.97 & 0.90 & --- & 0.10 & 0.1 \\
\hline $\mathrm{Mn}$ & 1.75 & 0.82 & 1.76 & 1.90 & 1.80 & 1.91 & 1.93 & 2.11 & 1.89 & --- & 0.27 & 0.1 \\
\hline $\mathrm{Na}$ & 8.63 & 3.12 & 8.38 & 8.29 & 8.16 & 8.45 & 8.48 & 7.93 & 8.37 & --- & 11.39 & 1.4 \\
\hline $\mathrm{Ni}$ & 0.55 & 0.22 & 0.53 & 0.56 & 0.56 & 0.54 & 0.54 & 0.59 & 0.55 & --- & 0.11 & 0.2 \\
\hline $\mathrm{P}$ & 0.05 & 0.01 & 0.03 & 0.03 & 0.03 & 0.02 & 0.03 & 0.02 & 0.02 & --- & 0.05 & 2.1 \\
\hline S & 0.05 & 0.042 & 0.05 & 0.07 & 0.07 & 0.09 & 0.08 & 0.12 & 0.08 & --- & 1.96 & 25.7 \\
\hline $\mathrm{Si}$ & 21.15 & 7.27 & 20.25 & 19.65 & 19.30 & 19.50 & 20.05 & 19.60 & 19.88 & --- & --- & --- \\
\hline $\mathrm{Ti}$ & 0.42 & 0.0094 & 0.18 & 0.11 & 0.12 & 0.05 & 0.11 & 0.04 & 0.11 & --- & 0.01 & 0.1 \\
\hline $\mathrm{Zn}$ & 0.02 & 0.0076 & 0.04 & 0.03 & 0.03 & 0.02 & 0.03 & 0.02 & 0.03 & --- & 2.33 & 78.3 \\
\hline $\mathrm{Zr}$ & 0.16 & 0.015 & 0.23 & 0.13 & 0.14 & 0.06 & 0.13 & 0.05 & 0.13 & --- & 0.03 & 0.2 \\
\hline Totals & 55.30 & 20.73 & 54.07 & 53.97 & 52.92 & 54.04 & 54.90 & 54.67 & 54.35 & --- & 37.33 & --- \\
\hline $\begin{array}{l}\text { Anions, wt \% } \\
\text { Chloride }\end{array}$ & 0.26 & 0.44 & 0.26 & 0.52 & 0.43 & 0.52 & 0.54 & 0.85 & 0.49 & --- & --- & --- \\
\hline Nitrite & $<0.10$ & 0.43 & $0.10<$ & $0.10<$ & $0.10<$ & 0.10 & 0.10 & 0.10 & 0.10 & --- & --- & --- \\
\hline Nitrate & $<0.05$ & 2.69 & $0.05<$ & $0.05<$ & $0.05<$ & 0.05 & 0.05 & 0.05 & 0.05 & --- & --- & --- \\
\hline $\begin{array}{l}\text { Formate } \\
(\mathrm{COOH})\end{array}$ & $<0.05$ & 5.08 & $0.05<$ & $0.05<$ & $0.05<$ & 0.05 & 0.05 & 0.05 & 0.05 & --- & --- & --- \\
\hline Sulfate & 0.14 & 0.11 & 0.12 & 0.21 & 0.18 & 0.23 & 0.21 & 0.35 & 0.21 & --- & --- & --- \\
\hline Phosphate & $0.11<$ & 0.01 & 0.07 & 0.05 & 0.06 & 0.04 & 0.07 & 0.04 & 0.06 & --- & --- & --- \\
\hline $\begin{array}{l}\text { Glass specific } \\
\text { gravity }\end{array}$ & 2.69 & --- & 2.67 & 2.65 & 2.64 & 2.67 & 2.63 & --- & 2.65 & --- & --- & --- \\
\hline $\begin{array}{l}\text { Glass REDOX } \\
\text { values, } \\
\mathrm{Fe}^{+2} / \mathrm{Fe}^{(\text {tot })}\end{array}$ & 0.053 & --- & 0.128 & 0.073 & $0.08<$ & 0.05 & 0.071 & --- & 0.080 & --- & ---- & --- \\
\hline $\begin{array}{l}\text { Notes: } \\
\text { 1. The amount }\end{array}$ & os opt & . & 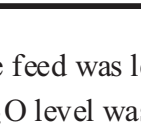 & 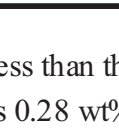 & . & 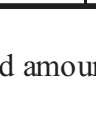 & 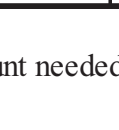 & & - & 4 & 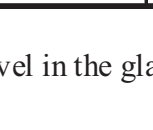 & $s$ of \\
\hline
\end{tabular}


The glass specific gravity was constant from sample to sample, and averaged 2.65, consistent with the expected specific gravity for this glass.

The glass REDOX ratio varied somewhat, perhaps because of the expectedly low $\mathrm{Fe}^{+2}$ values that were near the analytical detection limit. The REDOX ratio for the first glass pour, at 0.128 , was higher than for the other glass samples, which ranged between non-detect at 0.045 to -0.078 . This was due to the use of the graphite starter ring at the demonstration start. After the first glass drain, the glass REDOX ratio was relatively stable and low, indicating that the reducing effects of the graphite starter ring were eliminated as time passed and as some of the more reduced glass was removed in the first drain period.

Table 6-7 and Figure 6-13 show the mass balance closure (mass out / mass in) for metals and total solids. The total calcined solids mass balance closure, at 1.01, is acceptable considering potential experimental error. The mass balance closure for all of the metals present in the feed at concentrations greater than $1 \mathrm{wt} \%$ (Al, B, Fe, Li, $\mathrm{Mn}, \mathrm{Na}$, and $\mathrm{Si}$ ) ranged between 0.92 and 1.01, within reasonable experimental and analytical error for these metals. The mass balance closure ranged between 0.84 and 1.12 for all metals present in the feed at concentrations less than $1 \mathrm{wt} \%$, except for $\mathrm{Zn}$ and $\mathrm{Zr}$. The output streams appear to have a small amount of $\mathrm{Zn}$ and $\mathrm{Zr}$ contamination or positive bias, causing the mass balance closure for these two metals to be 1.77 and 1.91 , respectively. The concentrations of these metals in the feed simulant was 0.01 and $0.02 \mathrm{wt} \%$, respectively, so even a small amount of contamination or bias could cause these high mass balance closure values.

Figure 6-14 shows that the concentrations of metals (including $\mathrm{Cs}, \mathrm{K}, \mathrm{S}$, and $\mathrm{Zn}$ ) that can form more volatile species at elevated temperatures are enriched in the off-gas PM, compared to the concentrations of the same metals in the glass product. Concentrations of less volatile metals are depleted in the off-gas PM, due to the dilution of the off-gas PM by the enriched concentrations of the more volatile metals. The weighted average concentration of Cs in the off-gas solids, at about $12 \mathrm{wt} \%$, was enriched to about 42 times the concentration of $\mathrm{Cs}$ in the weighted average glass composition, where-as the Fe concentration in the off-gas PM was reduced by 10 times compared to the Fe concentration in the glass. Sulfur was enriched about 26 times higher than the $\mathrm{S}$ concentrations in the glass.

Figure 6-15 shows the average partitioning of metals and total solids to the off-gas. These partitioning calculations were made using only the compositions and masses of the melter output streams - the product glass, deposits removed from the melter freeboard and off-gas pipe upstream of the off-gas PM and metals sample location, and the PM and metals results. This approach reduces the impact of nonunity elemental mass balance closure on the partitioning results.

The more-volatile metals partitioned to the off-gas in proportions greater than the total solids partitioning value of $0.26 \%$. The less-volatile metals partitioned to the off-gas less than the total solids partitioning value. For example, about $11 \%$ of the Cs partitioned to the off-gas on average, whereas only $0.03 \%$ of the Fe partitioned to the off-gas.

Instantaneous metals partitioning data for each demonstration condition were determined from the instantaneous mass flowrates of the metals in the feed and in the melter off-gas determined from the Method 29 off-gas samples. These results are shown in Table 6-8 and Figure 6-16. Like the average partitioning results, metals that are known to be less volatile at elevated temperatures (such as $\mathrm{Al}$ and $\mathrm{Fe}$ ) partition to off-gas about 10 times less than for the total calcined solids. The instantaneous partitioning results for those metals known to more volatile (Cs, K, S, and $\mathrm{Zn}$ ) range $10-100$ times higher than for the total calcined solids. This figure also shows that increasing the cold cap coverage from 70 to $95 \%$ tended to reduce the partitioning of both less-volatile and more-volatile metals. Cs partitioning to the offgas decreased from about $17 \%$ to about $10 \%$ when the cold cap coverage increased from 70 to $90-95 \%$. 


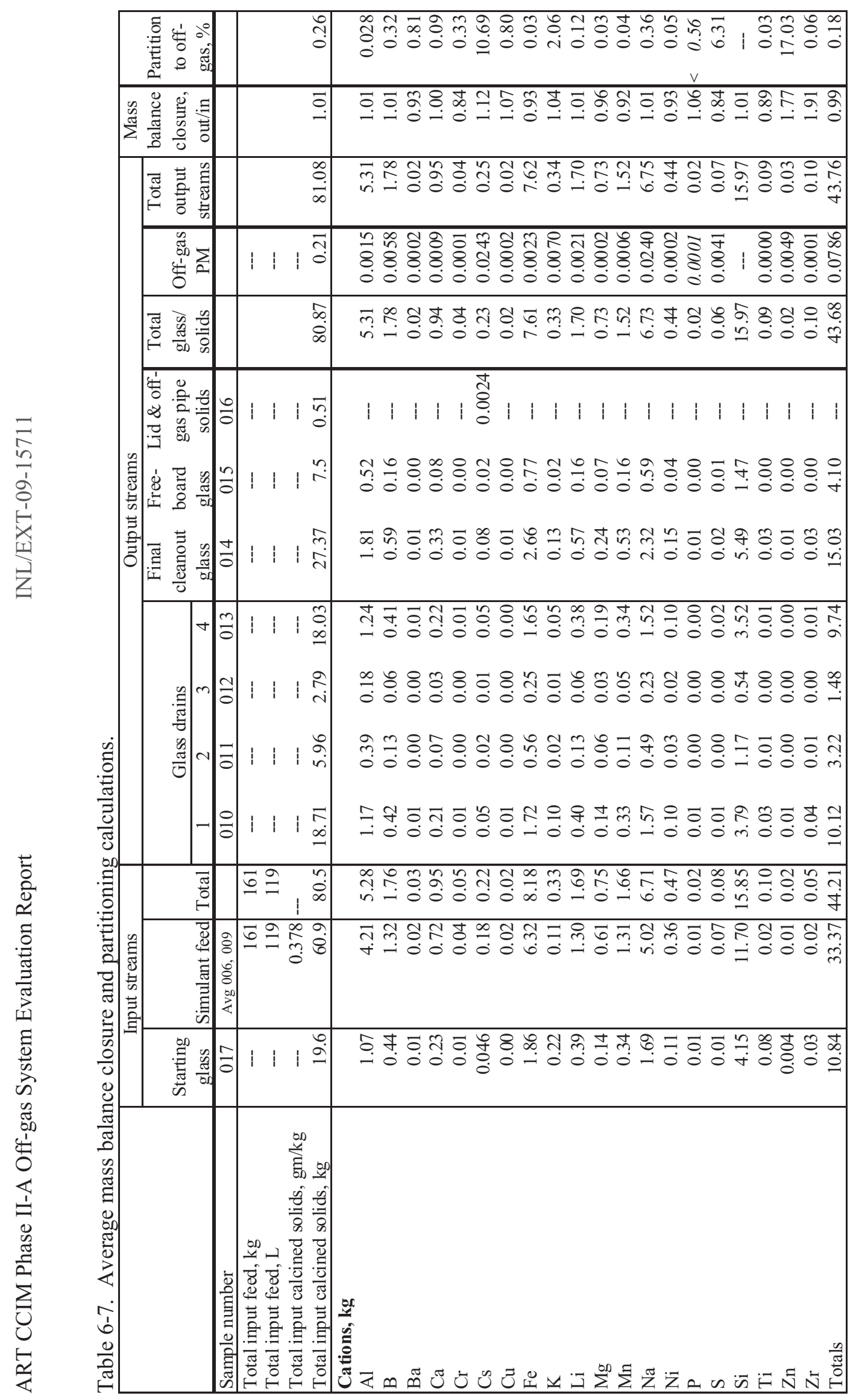




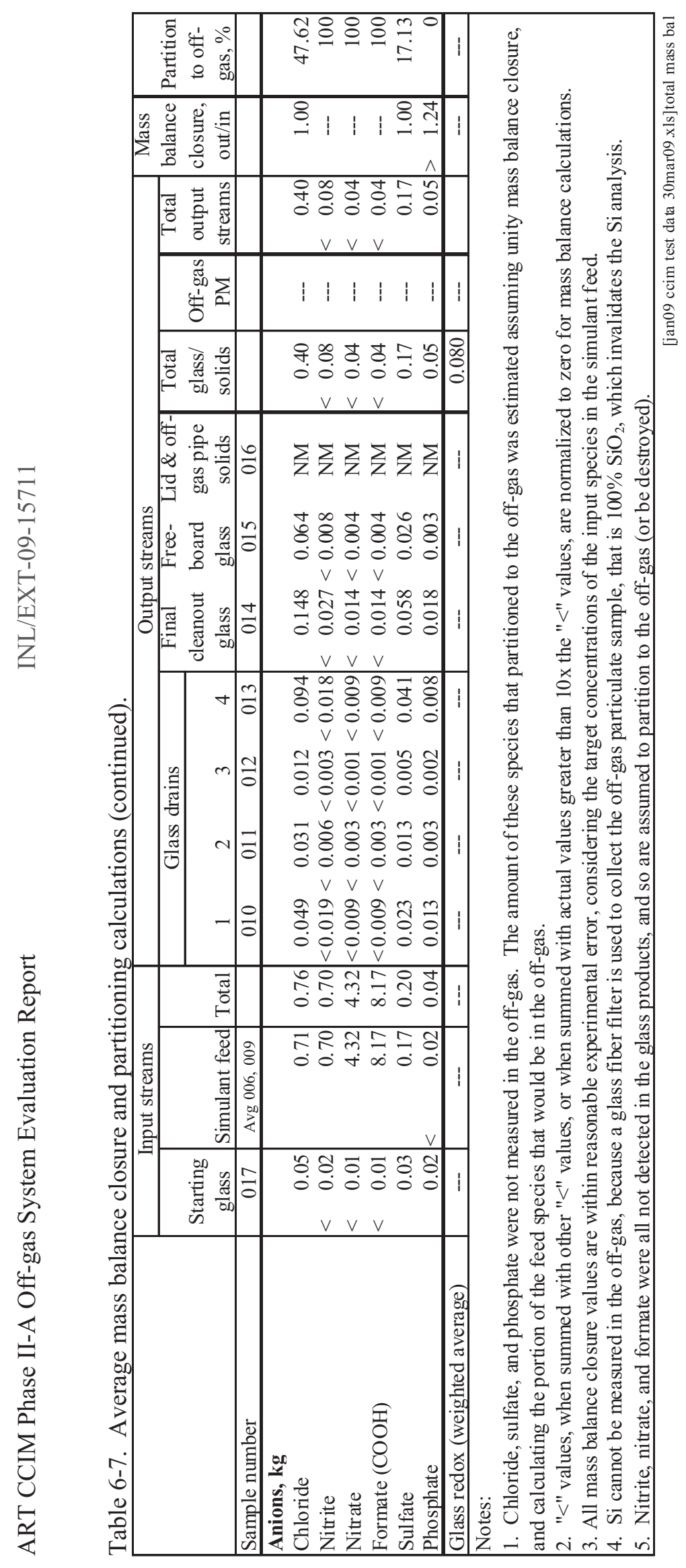




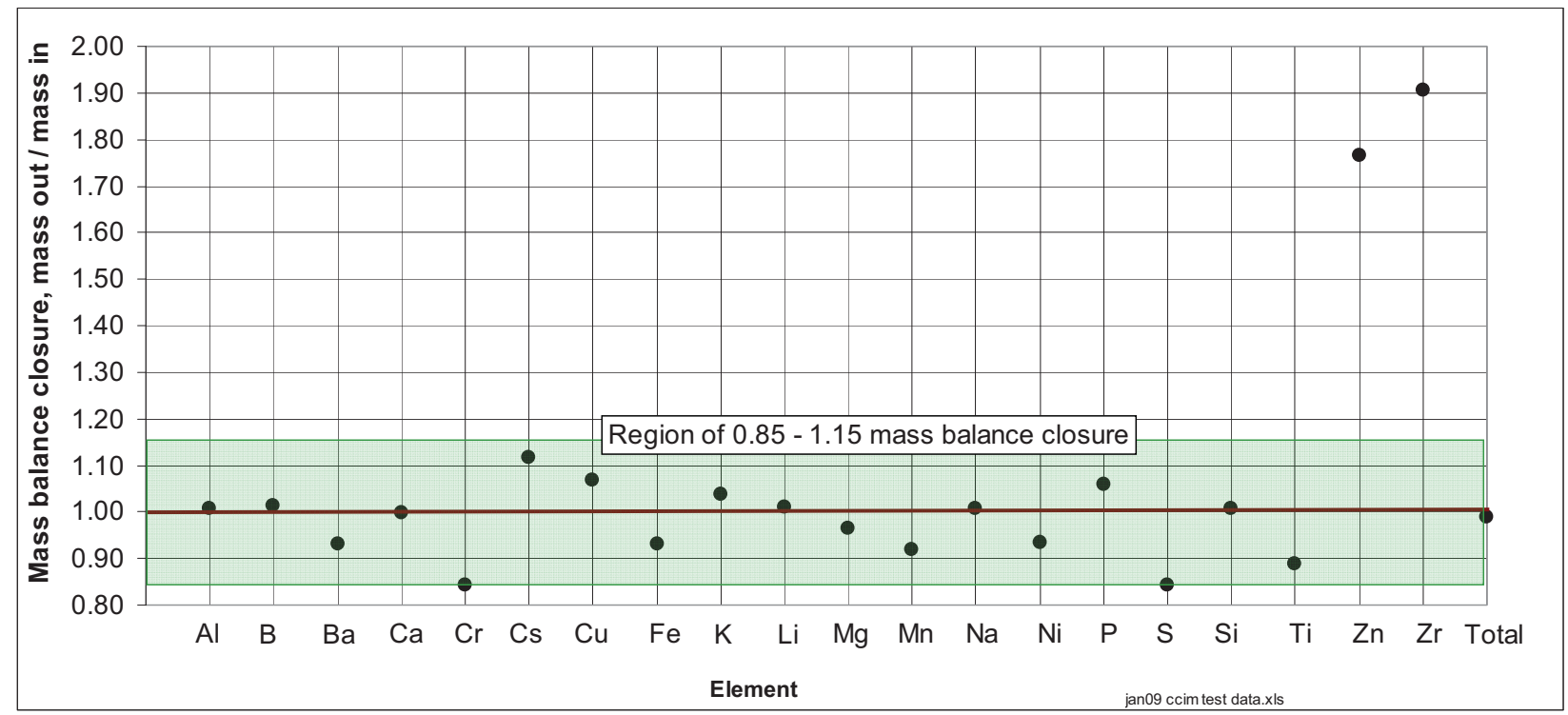

Figure 6-13. Average elemental and total solid mass balance closure.

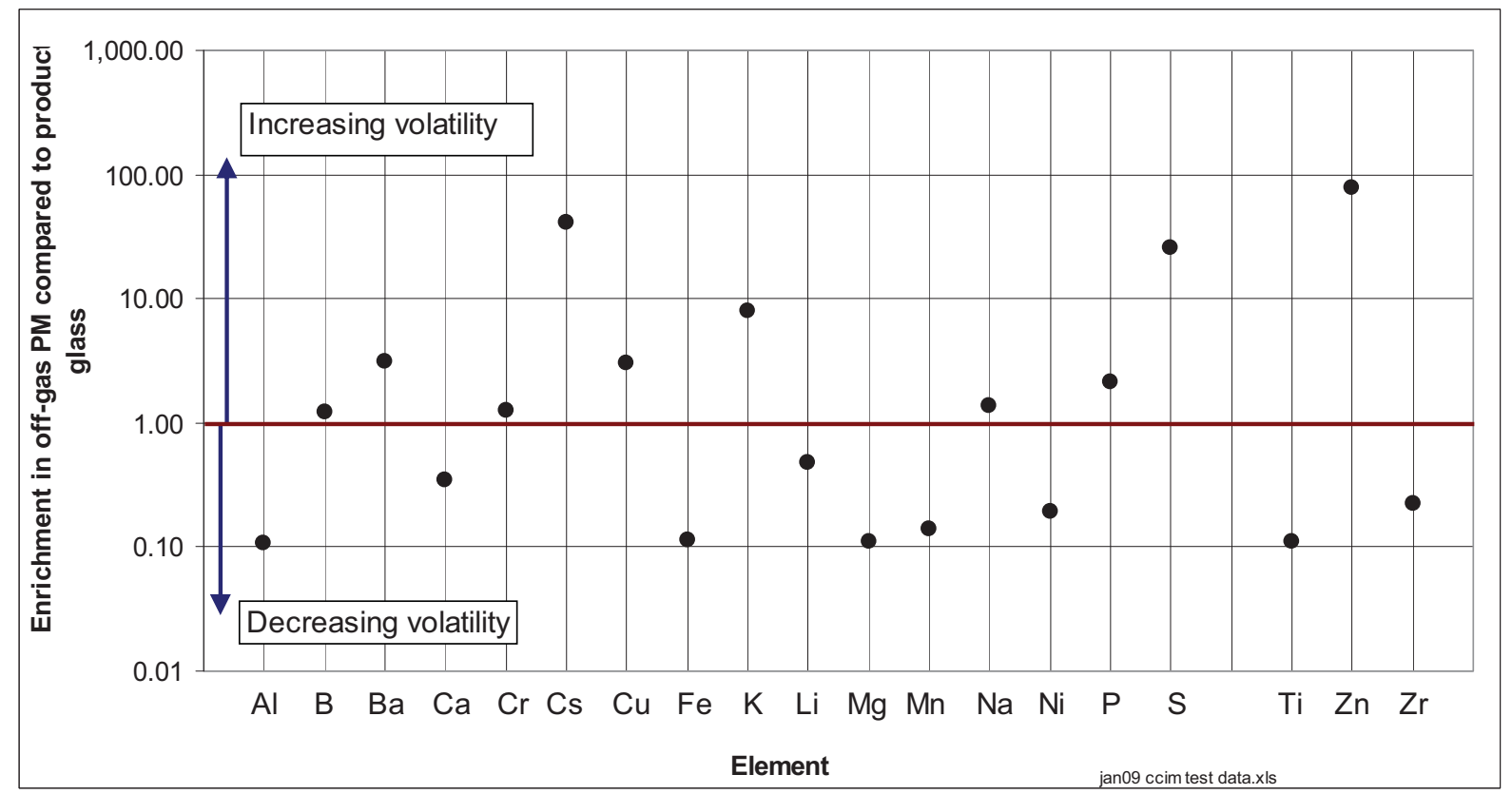

Figure 6-14. Average enrichment/depletion of metals concentrations in the off-gas particulate matter. 


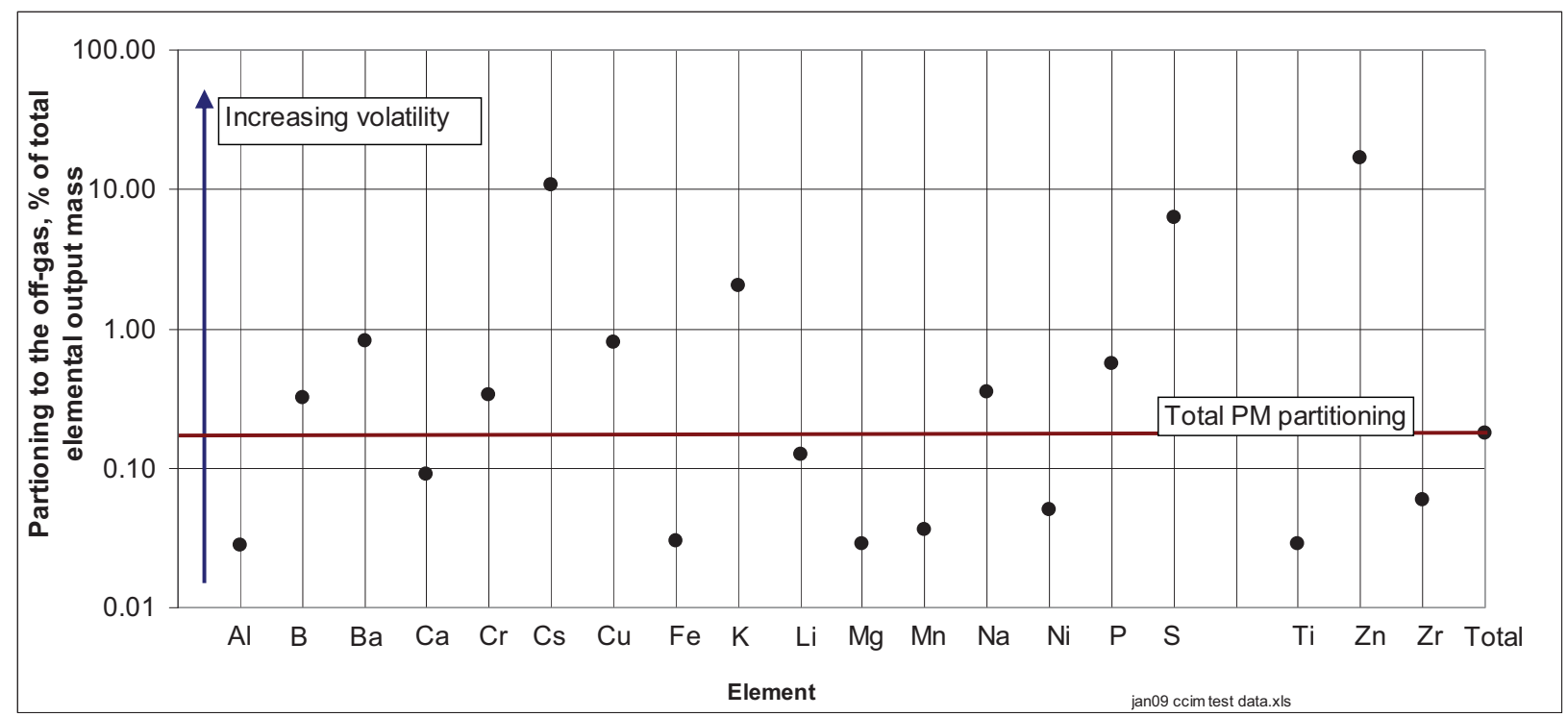

Figure 6-15. Average metals and total solids partitioning to the off-gas. 
Table 6-8. Instantaneous metals partitioning for the different demonstration conditions.

\begin{tabular}{|c|c|c|c|c|c|c|c|c|}
\hline & \multicolumn{4}{|c|}{ Metals input rates, $\mathrm{mg} / \mathrm{hr}$} & \multicolumn{4}{|c|}{ Metals partitioning to offgas, $\%$} \\
\hline & \multicolumn{4}{|c|}{ Off-gas test } & \multicolumn{4}{|c|}{ Off-gas test } \\
\hline & 1 & 2 & 3 & 4 & 1 & 2 & 3 & 4 \\
\hline cold cap coverage, $\%$ & 90 & 95 & 70 & 90 & 90 & 95 & 70 & 90 \\
\hline Test condition & 1 & 1 & 2 & 3 & 1 & 1 & 2 & 3 \\
\hline $\mathrm{Al}$ & 100,752 & 100,752 & 59,607 & 109,919 & 0.05 & 0.02 & 0.04 & 0.04 \\
\hline B & 31,731 & 31,731 & 18,773 & 34,618 & 0.42 & 0.38 & 0.51 & 0.40 \\
\hline $\mathrm{Ba}$ & 437 & 437 & 259 & 477 & 2.60 & 0.68 & 0.70 & 0.68 \\
\hline $\mathrm{Ca}$ & 17,029 & 17,029 & 10,075 & 18,578 & 0.28 & 0.04 & 0.08 & 0.13 \\
\hline $\mathrm{Cr}$ & 791 & 791 & 468 & 863 & 0.12 & 0.39 & 0.66 & 0.37 \\
\hline Cs & 4,714 & 4,714 & 2,789 & 5,143 & 6.67 & 12.78 & 16.88 & 10.68 \\
\hline $\mathrm{Cu}$ & 417 & 417 & 247 & 455 & 0.47 & 1.19 & 1.35 & 0.94 \\
\hline $\mathrm{Fe}$ & 139,864 & 139,864 & 82,747 & 152,589 & 0.03 & 0.02 & 0.05 & 0.04 \\
\hline $\mathrm{K}$ & 2,656 & 2,656 & 1,571 & 2,897 & 5.57 & 5.83 & 7.98 & 5.11 \\
\hline $\mathrm{Li}$ & 31,134 & 31,134 & 18,420 & 33,967 & 0.09 & 0.14 & 0.24 & 0.14 \\
\hline $\mathrm{Mg}$ & 14,093 & 14,093 & 8,338 & 15,376 & 0.04 & 0.02 & 0.04 & 0.04 \\
\hline $\mathrm{Mn}$ & 28,707 & 28,707 & 16,984 & 31,319 & 0.04 & 0.03 & 0.06 & 0.05 \\
\hline $\mathrm{Na}$ & 120,049 & 120,049 & 71,024 & 130,972 & 0.43 & 0.37 & 0.60 & 0.48 \\
\hline $\mathrm{Ni}$ & 8,026 & 8,026 & 4,748 & 8,756 & 0.05 & 0.04 & 0.09 & 0.07 \\
\hline $\mathrm{P}$ & 218 & 218 & 129 & 238 & 1.21 & 1.10 & 1.38 & 1.14 \\
\hline S & 1,342 & 1,342 & 794 & 1,465 & 5.08 & 5.04 & 11.53 & 5.30 \\
\hline $\mathrm{Si}$ & 280,290 & 280,290 & 165,826 & 305,791 & --- & --- & --- & --- \\
\hline $\mathrm{Ti}$ & 321 & 321 & 190 & 351 & 0.38 & 0.18 & 0.12 & 0.08 \\
\hline $\mathrm{Zn}$ & 517 & 517 & 306 & 564 & 22.13 & 20.86 & 26.06 & 21.48 \\
\hline $\mathrm{Zr}$ & 1,074 & 1,074 & 635 & 1,171 & 0.15 & 0.12 & 0.15 & 0.13 \\
\hline
\end{tabular}

Notes:

1. Italic values are detection limit values for elements that were not detected.

2. The metals partitioning data have been adjusted for each metal mass balance closure, so that the partitioning results are not biased by non-unity mass balance closures. This adjustment was done by normalizing the input metal mass flowrate by the mass balance closure value for that element.

3. The initial mass of the starting glass, and the mass of deposits recovered from the melter freeboard and off-gas pipe, are not included in these calculations, because these calculations only apply to the off-gas sampling periods. 


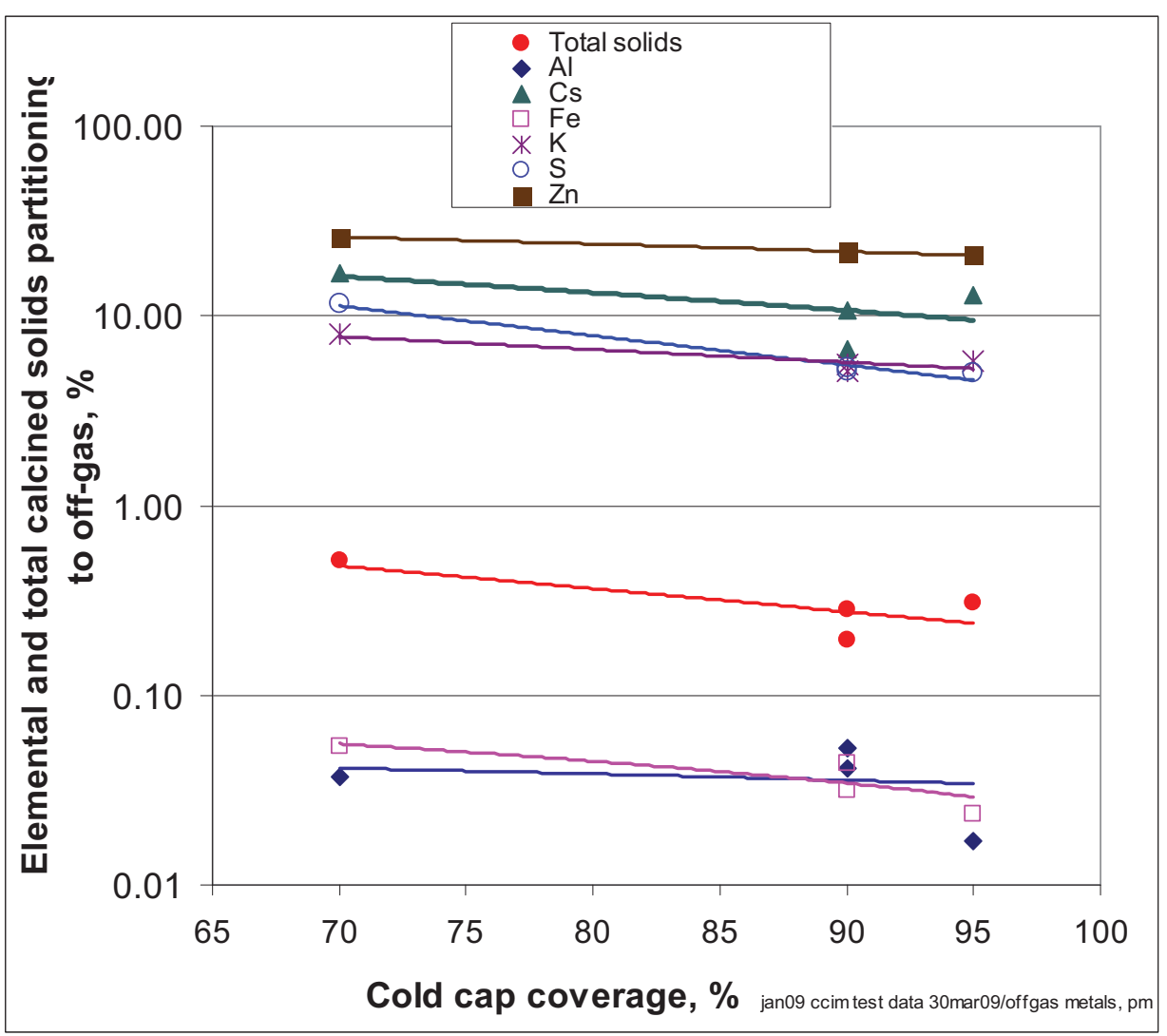

Figure 6-16. Metals and total calcined solids partitioning to the off-gas for different cold cap coverages.

\section{SUMMARY AND CONCLUSIONS}

A simulant of the DWPF SB4 feed was successfully fed and melted in a pilot-scale CCIM system during two demonstration runs. The OGSE demonstration provide initial results that (a) provide melter operating conditions while feeding a DWPF SB4 simulant feed, (b) determine the fate of feed organic and metal feed constituents and metals partitioning, and (c) characterize the melter off-gas source term to a downstream off-gas system.

The INL CCIM demonstration system was operated continuously for about 30 hours during the parametric demonstration, and for about 58 hours during the OGSE demonstration. The first demonstration series provided a parametric evaluation of operating conditions to enable the operators to determine how to operate each subsystem within target ranges, and in some cases determine what those ranges are.

Following the initial parametric evaluation, a selected number of operating conditions was defined for longer-term operation, process measurements, and process sampling to meet demonstration objectives during the OGSE demonstration. The OGSE demonstration included sample collection for analysis of all input and output streams, so that laboratory analyses and mass balances could be used to determine the fate of feed constituents, especially Cs. 


\subsection{Melter Operating Conditions}

Starting glass, manually added to the crucible prior to the demonstration, was quickly heated and became molten and ready for simulant feed within 3-4 hours after power startup.

The simulant feedrate was varied from $1.0-4.5 \mathrm{~kg} / \mathrm{hr}$, and averaged $2.3-4.2 \mathrm{~kg} / \mathrm{hr}$ during three different demonstration conditions performed during the OGSE demonstration. These feedrates corresponded to specific feedrates that ranged between $40-75 \mathrm{~kg} / \mathrm{hr} / \mathrm{m}^{2}$ melt surface area $(0.09-0.16$ $\mathrm{kg} / \mathrm{hr} / \mathrm{kW}$ ). The induction power system was operated at a frequency of about $1.7 \mathrm{MHz}$, which was close to the target of $1.6 \mathrm{MHz}$ needed for representative scaling to the larger melter at Marcoule.

The three OGSE demonstration conditions were:

1. Essentially complete cold cap, nominal $1,250^{\circ} \mathrm{C}$ melt temperature, simulant feedrate nominally $3.8 \mathrm{~kg} / \mathrm{hr}$.

2. Less complete cold cap, nominal $1,250^{\circ} \mathrm{C}$ melt temperature, simulant feedrate at nominally 2.3 $\mathrm{kg} / \mathrm{hr}$ (lower feedrate to enable less complete cold cap coverage).

3. Essentially complete cold cap, nominal $1,300^{\circ} \mathrm{C}$ melt temperature, simulant feedrate at $4.1 \mathrm{~kg} / \mathrm{hr}$ (slightly higher feedrate to maintain cold cap).

A total of $161 \mathrm{~kg}$ of feed was processed during the OGSE demonstration, producing about $61 \mathrm{~kg}$ of product glass. The simulant feed was continuous, and glass draining was periodically performed upon demand as the crucible gradually filled with glass. As the feed was fed to the melter, the glass level increased until a portion of the molten glass was drained from the melter.

The cold cap coverage was controlled by adjusting the feedrate and melter power levels to obtain the target molten glass temperatures with varying cold cap levels. The melter freeboard temperature was sensitive to the extent of cold cap coverage, because the cold cap reduced thermal radiation from the molten glass.

The melt temperature was measured using a thermocouple that could be raised or lowered so that it provided a representative melt temperature. The melt temperature was relatively constant between the melt bottom up to $12 \mathrm{~cm}$ high ( $16 \mathrm{~cm}$ below the melt surface). The melt temperature TC was typically 5 $8 \mathrm{~cm}$ above the bottom of the melter, at a depth where the melt temperature was fairly constant.

\subsection{Melter Off-gas Measurements}

The melter off-gas composition was measured on a dry basis and then normalized to a wet basis using the measured off-gas moisture content, to more realistically portray the actual off-gas concentrations. This is important when considering such issues as off-gas flammability and $\mathrm{NO}_{\mathrm{x}}$ concentrations, because the actual concentrations, being on a wet basis, are diluted by moisture and are lower than the as-measured values.

The $\mathrm{CO}_{2}, \mathrm{CO}, \mathrm{CH}_{4}, \mathrm{THC}$, and $\mathrm{NO}_{\mathrm{x}}$ levels tended to increase with increasing feedrate. The $\mathrm{NO}_{\mathrm{x}}$ level was higher during Condition 3 when the target melt temperature $\left(1,300^{\circ} \mathrm{C}\right)$ and the feedrate were higher. The $\mathrm{H}_{2}$ levels were very close to detection limits based on the range of the analyzer, and so experienced more scatter than the other measurements. Considering the importance of the $\mathrm{H}_{2}$ measurement, GC analysis of summa canister TO-14 grab samples were used to confirm the low levels measured by the CEMS. The summa can sample analyses also showed that all VOCs included in the GC/MS scan were not detected at levels above the method detection limit or reporting limit. 
Melter off-gas flammability is sometimes a concern when an organic reductant such as formic acid $(\mathrm{HCOOH})$ is used, as in this demonstration. About $98 \%$ of the carbon in the formate converted to $\mathrm{CO}_{2}$, and over $90 \%$ of the $\mathrm{H}$ converted to water vapor. Under $6-9 \%$ of the $\mathrm{H}$ in the formate converted to $\mathrm{H}_{2}$, and $2 \%$ of the formate decomposed to gaseous hydrocarbons or $\mathrm{CO}$. Wet basis $\mathrm{H}_{2}$ levels measured by the CEMS ranged between $0.05-0.07 \%, 30-40$ times lower than the $\mathrm{H}_{2}$ flammability limit in air. $\mathrm{H}_{2}$ was not detected at an even lower detection limit of $0.002 \%$ using the GC analysis of the summa canister samples. $\mathrm{H}_{2}$ levels at this detection limit are 1,000 times lower than the $\mathrm{H}_{2}$ flammability limit in air.

Dilution by air from the bubbler, view port purges, and air inleakage dilutes the off-gas evolved from evaporation, thermal decomposition, and REDOX reactions of the feed by a factor of 2-2.5 for the different demonstration conditions.

The formate reductant is added to the feed to achieve the desired glass REDOX conditions. The formate, and decomposition products of the formate, also react with nitrite, nitrate, and $\mathrm{NO}_{\mathrm{x}}$ decomposition products. A portion (about 38-44\%) of the $\mathrm{NO}_{\mathrm{x}}$ was destroyed when the target melt temperature was $1,250^{\circ} \mathrm{C} . \mathrm{NO}_{\mathrm{x}}$ destruction was lower, about $9 \%$, for the higher nominal $1,300^{\circ} \mathrm{C}$ melt temperature. Roughly $2 / 3$ of the total $\mathrm{NO}_{x}$ was $\mathrm{NO}_{2}$, and roughly $1 / 3$ was $\mathrm{NO}$. Other species such as $\mathrm{HNO}_{2}, \mathrm{HNO}_{3}$, and $\mathrm{N}_{2} \mathrm{O}$ were not measured, and, if present in the off-gas, are expected to be present at concentrations less than the $\mathrm{NO}$ and $\mathrm{NO}_{\mathrm{x}}$ concentrations.

The total PM concentration ranged from $12-29 \mathrm{mg} / \mathrm{wscf}(340-821 \mathrm{mg} / \mathrm{wncm})$ for the three OGSE demonstration conditions. The total PM emission rate ranged from $2.8-4.5 \mathrm{gm} / \mathrm{hr}$. This $\mathrm{PM}$ emission rate corresponds to $0.19-0.51 \%$ of the total solids input rate.

The metals concentrations and mass emission rates vary over three orders of magnitude, depending on the concentration of those metals in the feed, potential speciation of those metals, and volatility at elevated temperatures. The Cs emission rate was about 10 times higher than the $\mathrm{Fe}$ emission rate, even though the Cs concentration in the feed and the glass products was about 30 times lower than was the Fe concentration. This illustrates that even though off-gas emissions of the more volatile metals can be higher for nonvolatile metals, non-volatile metals are still entrained into the off-gas.

\subsection{Mass Balance and Partitioning Results}

Mass balances were performed using composition analyses, process rates, and masses of the input and output streams. While more volatile metals are more prone to volatilize from the melter at the elevated melter temperatures, all metals in the feed will evolve from the melter in dust entrained from the cold cap and in fume volatilized and physically ejected (through bubbling and entrainment in gas that passes through the cold cap and the melt surface). Physical and thermodynamic mechanisms that result in evolution of feed material into the off-gas that would otherwise be incorporated into the glass product include (a) volatilization at elevated melt temperatures, with or without subsequent condensation into "fume" particles, (b) physical entrainment in the melter off-gas of dust particles formed in the cold cap as the feed dries, and (c) physical ejection of molten glass aerosols through bubbling of gas in the melt or other turbulence.

The concentrations of the different glass drain samples varied little over time, and varied little from the glass samples removed from the melter after the demonstration end, and were also similar to the composition of the starting glass. The weighted average glass product composition was calculated for determining the average composition of the total glass product mass.

The glass specific gravity was essentially constant from sample to sample, and averaged 2.65 , consistent with the expected specific gravity for this glass. 
The glass REDOX ratio varied somewhat, perhaps because of the expectedly low $\mathrm{Fe}^{+2}$ values that were near the analytical detection limit. The REDOX ratio for the first glass pour, at 0.128 , was higher than for the other glass samples, which ranged between non-detect at 0.045 to -0.078 . This was due to the use of the graphite starter ring at the demonstration start. After the first glass drain, the glass REDOX ratio was relatively stable and low, indicating that the reducing effects of the graphite starter ring were eliminated as time passed and as some of the more reduced glass was removed in the first drain period.

The total solids mass balance closure, at 1.01, is acceptable considering potential experimental error. The mass balance closure for all of the metals present in the feed at concentrations greater than $1 \mathrm{wt} \%$ (Al, B, Fe, Li, Mn, Na, and Si) ranged between 0.92 and 1.01, within reasonable experimental and analytical error for these metals. The mass balance closure ranged between 0.84 and 1.12 for all metals present in the feed at concentrations less than $1 \mathrm{wt} \%$, except for $\mathrm{Zn}$ and $\mathrm{Zr}$. The output streams appear to have a small amount of $\mathrm{Zn}$ and $\mathrm{Zr}$ contamination or positive bias, causing the mass balance closure for these two metals to be 1.77 and 1.91 , respectively. The concentrations of these metals in the feed simulant was 0.01 and $0.02 \mathrm{wt} \%$, respectively, so even a small amount of contamination or bias could cause these high mass balance closure values.

The concentrations of more volatile metals (including Cs, K, S, and Zn) are enriched in the off-gas PM, compared to the concentrations of the same metals in the glass product. Concentrations of less volatile metals are depleted in the off-gas PM, due to the dilution of the off-gas PM by the enriched concentrations of the more volatile metals. The weighted average concentration of Cs in the off-gas solids, at about $12 \mathrm{wt} \%$, was enriched to about 42 times the concentration of $\mathrm{Cs}$ in the weighted average glass composition, where-as the Fe concentration in the off-gas PM was reduced by 10 times compared to the Fe concentration in the glass.

The more-volatile metals partition in proportions greater than the average total solids partitioning value. The less-volatile metals partitioned to the off-gas less than the total solids partitioning value. For example, about $11 \%$ of the Cs partitioned to the off-gas (on average), whereas only $0.03 \%$ of the Fe partitioned to the off-gas.

Increasing the cold cap coverage from 70 to $95 \%$ tended to reduce the partitioning of both lessvolatile and more-volatile metals. Cs partitioning to the off-gas decreased from about $17 \%$ to about $10 \%$ when the cold cap coverage was increased from 70 to $90-95 \%$.

\section{REFERENCES}

Girold, C. et al, 2008, "Proposed Configuration and Operating Conditions for the INL Demonstration," CEA memo to the ART CCIM Phase II-A participants, 10 September.

Marra, J. C., et al, 2008a, "Glass Formulation Development and Testing for Cold Crucible Induction Melter Technology Retrofit and Deployment Project, Phase II-A - Demonstrations, Lab-Scale Evaluation and Assessment Final Report," SRNS-STI-2008-00036, October.

Marra, Jim, et al, 2008b, "Formulation Development and Testing for Cold Crucible Induction Melter Technology Retrofit and Deployment Project: Lab-scale Evaluation and Assessment," 2008 Mid-year review, May 29.

Soelberg, Nick and Jay Roach, 2009, "ART CCIM Phase II-A Off-Gas System Evaluation Test Plan," INL-EXT-08-14449, February.

Tchemitcheff, Eric, 2009, personal communication "SB4 Waste Surrogate Frit 5-3-R6 and Startup Frit Analysis Tables.doc" emailed January 7, 2009. 